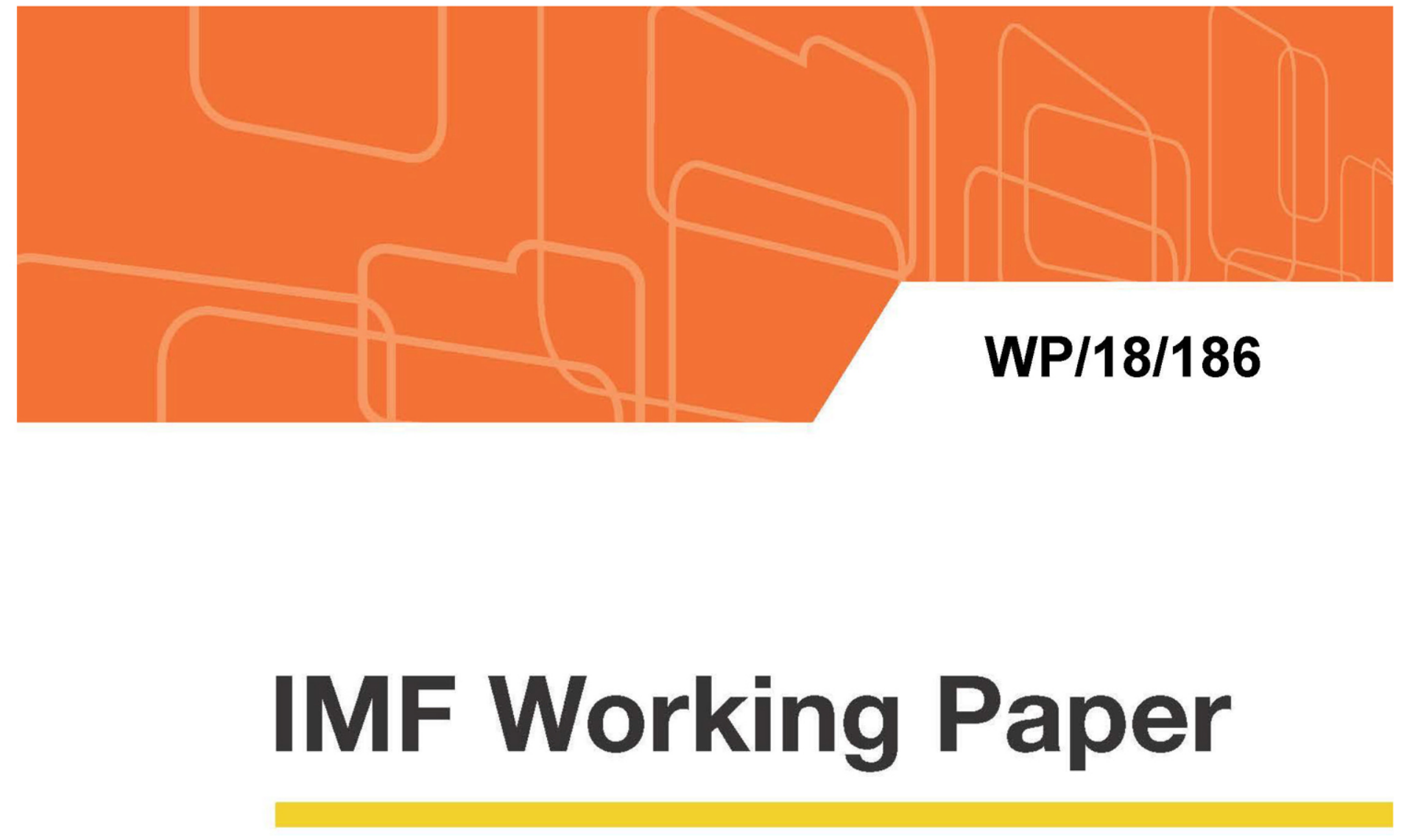

\title{
Employment Protection Deregulation and Labor Shares in Advanced Economies
}

by Gabriele Ciminelli ${ }^{1,2,3}$, Romain Duval ${ }^{1}$ and Davide Furceri ${ }^{1}$

\footnotetext{
1 International Monetary Fund

2 University of Amsterdam

3 Tinbergen Institute
}

IMF Working Papers describe research in progress by the author(s) and are published to elicit comments and to encourage debate. The views expressed in IMF Working Papers are those of the author(s) and do not necessarily represent the views of the IMF, its Executive Board, or IMF management. 


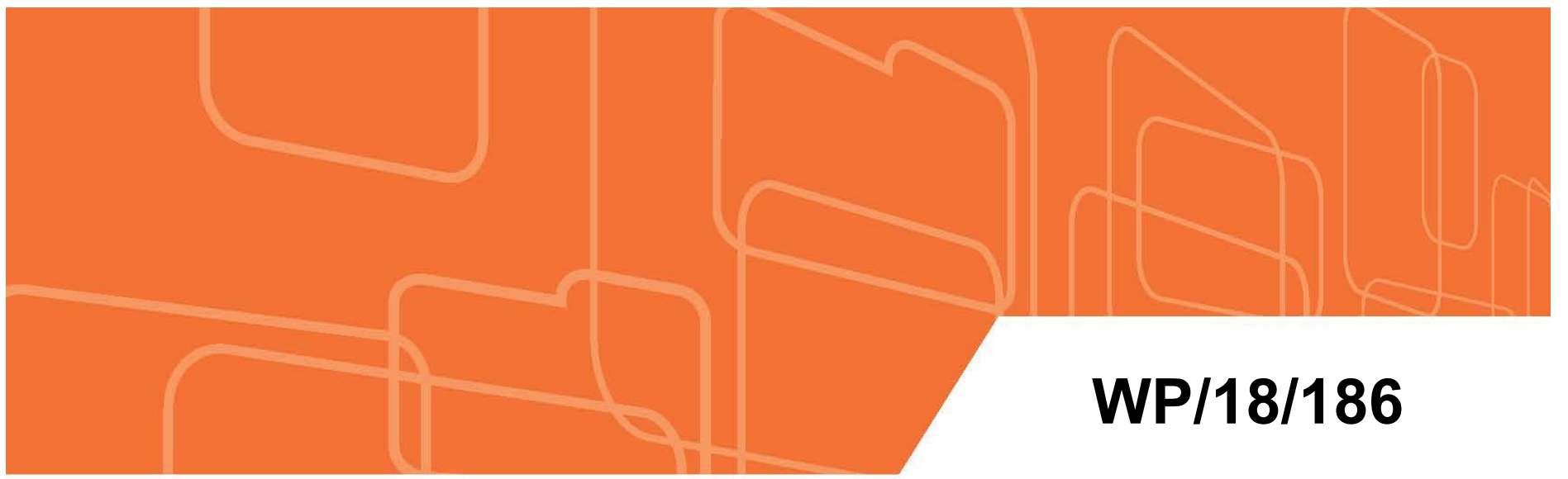

\section{IMF Working Paper}

\section{Employment Protection Deregulation and Labor Shares in Advanced Economies}

by Gabriele Ciminelli ${ }^{1,2,3}$, Romain Duval ${ }^{1}$ and Davide Furceri ${ }^{1}$

\footnotetext{
1 International Monetary Fund

2 University of Amsterdam

3 Tinbergen Institute
}

IMF Working Papers describe research in progress by the author(s) and are published to elicit comments and to encourage debate. The views expressed in IMF Working Papers are those of the author(s) and do not necessarily represent the views of the IMF, its Executive Board, or IMF management. 


\title{
IMF Working Paper
}

Research Department

\section{Employment Protection Deregulation and Labor Shares in Advanced Economies ${ }^{\mathrm{i}}$ Prepared by Gabriele Ciminelli, Romain Duval, and Davide Furceri}

Authorized for distribution by Romain Duval

August 2018

\section{IMF Working Papers describe research in progress by the author(s) and are published to elicit comments and to encourage debate. The views expressed in IMF Working Papers are those of the author(s) and do not necessarily represent the views of the IMF, its Executive Board, or IMF management.}

\begin{abstract}
Labor market deregulation, intended to boost productivity and employment, is one plausible, yet little studied, driver of the decline in labor shares that took place across most advanced economies since the early 1990s. This paper assesses the impact of job protection deregulation in a sample of 26 advanced economies over the period 1970-2015, using a newly constructed dataset of major reforms to employment protection legislation for regular contracts. We apply the local projection method to estimate the dynamic response of the labor share to our reform events at both the country and the country-industry levels. For the latter, we employ a differences-in-differences identification strategy using two identifying assumptions grounded in theory - namely that job protection deregulation should have larger negative effects in industries characterized by (i) a higher "natural" propensity to adjust the workforce, and (ii) a lower elasticity of substitution between capital and labor. We find a statistically significant, economically large and robust negative effect of deregulation on the labor share. In particular, illustrative back-of-the-envelope calculations suggest that job protection deregulation may have contributed about 15 percent to the average labor share decline in advanced economies. Together with existing evidence regarding the macroeconomic gains from job protection and other labor market reforms, our results also point to the need for policymakers to address efficiency-equity trade-offs when designing such reforms.
\end{abstract}

JEL Classification Numbers: E32; J21; J65; L43; O43; O47

Keywords: Structural Reforms, Labor Market, Deregulation, Employment Protection; Labor Share.

Author's E-Mail Address: gciminelli@imf.org,rduval@imf.org,dfurceri@imf.org

\footnotetext{
${ }^{\mathrm{i}}$ We thank Claudio Baccianti, Olivier Blanchard, Federico Diez, Massimo Giuliodori, Maurice Obstfeld, Jonathan Ostry, Aysegul Sahin, Francesco Venturini, and participants at the 13th Joint ECB/CEPR Labour Market Workshop, the ADBI Workshop on Labor Income Share in Asia, the IMF Jobs, Growth, Structural Reform and the Tinbergen Institute seminar series for helpful comments and discussion.
} 


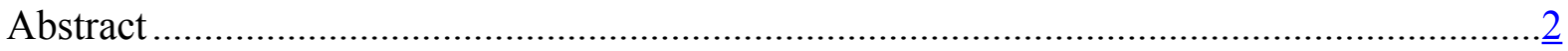

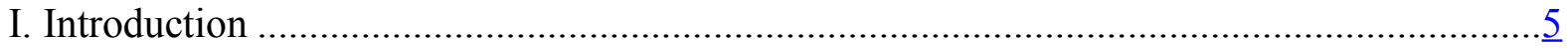

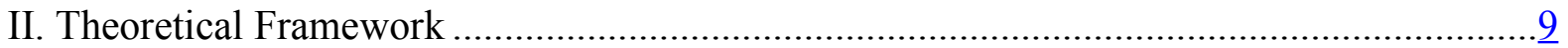

A. Competitive Labor Market ............................................................................

B. Bargaining Under the Right-to-Manage Model ........................................... 10

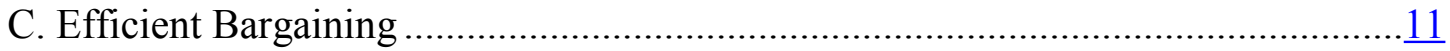

D. Implications for the Empirical Analysis …................................................ 12

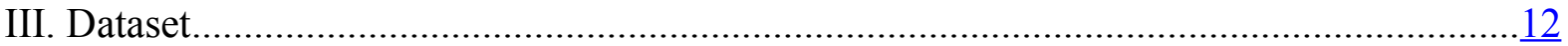

A. Employment Protection Legislation Reforms …........................................ $\frac{13}{14}$

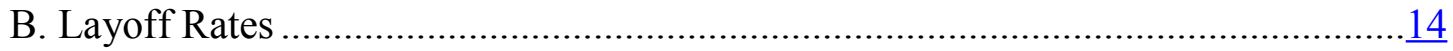

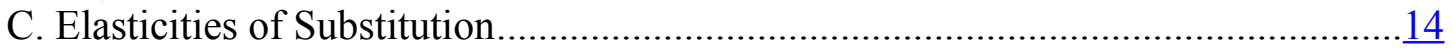

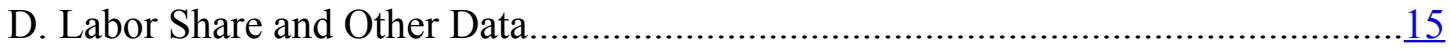

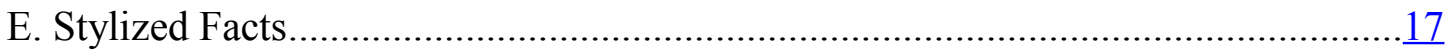

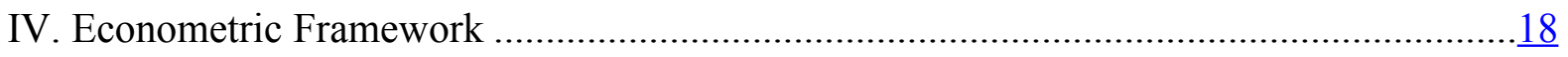

V. Baseline Results and Robustness Checks ................................................................ 21

A. Country-level Analysis .............................................................................

B. Country-industry Level Analysis ..............................................................

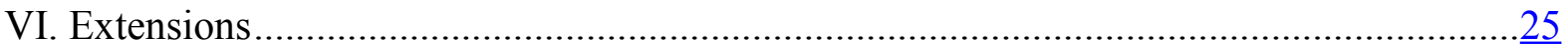

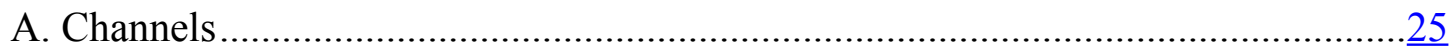

B. EOS Above Versus Below 1 ......................................................................... 26

C. Back-of-the Envelope Calculation of the Contribution of Job Protection

Deregulation to the Overall Decline in Labor Shares ...............................................

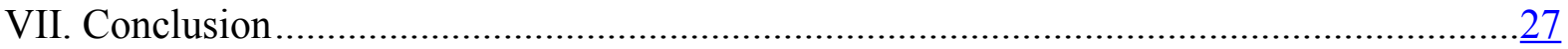

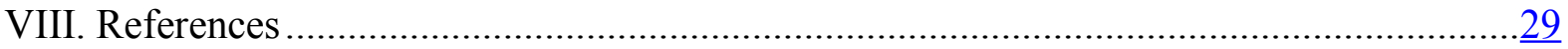

Figures

1. Cumulative Changes in Country Labor Shares Around Reform Years .............................34

2. Cumulative Changes in Industry Labor Shares Around Reform Years by Industry ............ $\underline{35}$

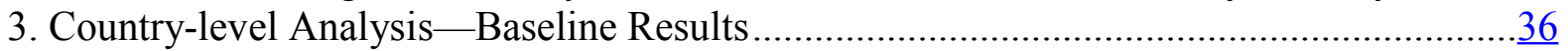

4. Country-industry-level Analysis_-Baseline Results ................................................. $\frac{37}{38}$

5. Country-industry-level Analysis: Robustness to Excluding Individual Countries ............... $\underline{38}$

6. Country-industry-level Analysis: Robustness to Excluding Individual Industries...............39

Tables

1. Country-level Analysis: Robustness Checks …..................................................... 40

2. Country-industry-level Analysis: Robustness Checks on Lag Specification ..................... 40

3. Country-industry-level Analysis: Robustness Checks on Sample Composition ................. 41

4. Country-industry Analysis: Robustness Checks on the Layoff Rates ............................. 42 
5. Country-industry Analysis: Robustness Checks on the Elasticities of Substitution............ $\underline{42}$

6. Country-industry-level Analysis: Robustness Checks on Potential Omitted .................... 43

7. Country-industry-level Analysis: Extension on Labor Share Drivers .............................43

8. Country-industry-level Analysis: Extension on Sample Split According to Elasticity of...44

Appendixes

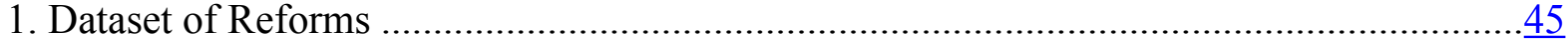

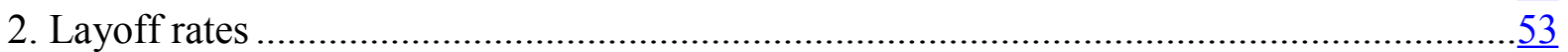

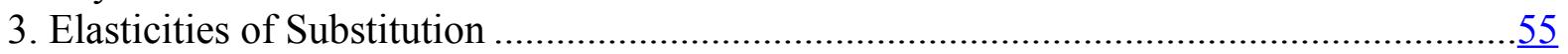

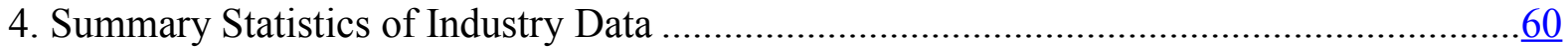

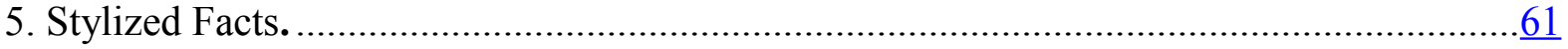

6. Back-to-the-envelope Calculation Using Country-industry-level Estimates...................... 


\section{INTRODUCTION}

Since the 1980s labor shares have trended downwards in many countries around the world (Karabarbounis and Neiman, 2014). This trend accelerated in the 1990s, and it has been particularly pronounced in advanced economies (IMF, 2017; OECD, 2012). Such a decline flies in the face of the predominant view in macroeconomics, since Kaldor $(1957,1961)$, that the labor share tends to be stable over the long run. This has triggered renewed interest in the drivers of labor shares, with particular focus on the roles of technological progress in equipment goods and implied substitution of capital for routine labor tasks (Karabarbounis and Neiman, 2013; Alvarez-Cuadrado et al., 2015; Eden and Gaggl, 2015; Acemoglu and Restrepo, 2016; Dao et al., 2017), rising concentration and pricing power across markets (Autor et al., 2017; Barkai, 2017), globalization of trade, finance and production (Elsby et al. 2013; Boehm et al., 2017; Dao et al., 2017; Furceri et al., 2017), and measurement issues (Rognlie, 2015; Koh et al., 2016; Bridgman, 2017). This paper contends that, alongside these (non-mutuallyexclusive) drivers, changes in institutions that weakened worker bargaining power have also played a role. While the point is general, for identification purposes we focus narrowly on job protection deregulation aimed at enhancing the functioning of labor markets. We empirically show that such deregulation contributed to some of the observed decline in labor shares in many advanced economies_-possibly a little over a tenth overall, keeping in mind that this estimate abstracts from other policy and non-policy changes that may also have weakened worker bargaining power in recent decades.

The analysis covers 26 advanced economies over the period 1970-2015. To capture labor market deregulation, we make use of a unique "narrative" cross-country dataset of major reforms of employment protection legislation (EPL) for regular workers, compiled in a companion paper (see Duval et al., 2018). Strikingly, in the five years after major reforms, the aggregate labor share declined by more than seven tenth of a percentage point in reforming countries, on average, compared to status quo countries.

We test empirically for this stylized fact applying the local projection method (Jordà, 2005) to trace out the response of the labor share to our reform events. To gauge the macroeconomic effects of EPL reforms on the labor share we first carry out the analysis at the country-time level. Next, to understand the underlying channels, we focus on the country-industry-time 
level. For the latter, we apply a differences-in-differences identification strategy à la Rajan and Zingales (1998), using two alternative identifying assumptions that are grounded in theory. First, following Micco and Pagés (2006) and Basannini et al. (2009), stringent dismissal regulations are more binding, and therefore should have a larger impact, in industries where firms have a higher "natural" propensity to regularly adjust their workforce - that is, a higher "natural" layoff rate. Second, following Blanchard and Giavazzi (2003) and Bentolila and Saint-Paul (2003), insofar as EPL affects workers' bargaining power and wage bargaining conforms at least in part to a Right-to-Manage model, deregulation lowers wage rents and triggers substitution of labor for capital, with an impact on the labor share that depends on the elasticity of substitution between these factors. The upshot is that deregulation is more likely to reduce the labor share in industries characterized by a lower degree of substitutability between capital and labor.

There are two further advantages of having a three-dimensional ( $i$ industries, $j$ countries and $t$ time periods) dataset:

- $\quad$ First, it allows us to control for country- and industry-specific time varying unobserved factors, such as macroeconomic shocks, as well as country-industry time invariant characteristics by including country-time $(j, t)$, industry-time $(i, t)$ and countryindustry $(j, i)$ fixed effects. The inclusion of the country-time fixed effects is particularly important as it absorbs any unobserved cross-country heterogeneity in macroeconomic conditions and policies that affect labor shares in a similar way across industries. In a pure cross-country time-series analysis, this would not be possible, leaving open the possibility that the impact attributed to EPL reforms could be due to other unobserved factors. Similarly, the inclusion of industry-time $(i, t)$ fixed effects absorbs any unobserved industry-specific developments that may affect industry labor shares in a similar way across countries, such as for instance the adoption of new technology.

- Second, it mitigates concerns about reverse causality. While it is typically difficult to identify causal effects using cross-country time-series data, it is much more likely that EPL reforms affect cross-industry differences in labor shares than the other way around. Since we control for country-time fixed effects - and therefore for aggregate labor shares - reverse causality in our set-up would imply that differences in labor shares across 
industries influence the probability of reforms at the aggregate level. Moreover, our main independent variable is the interaction between job protection reforms and industryspecific factors (natural layoff rates and/or elasticities of substitution); this makes it even less plausible that causality runs from the industry-level labor share to these composite variables.

To further strengthen the causal interpretation of our results, we verify their robustness to the inclusion of several additional controls whose omission could bias our estimatesincluding past and expected values of GDP growth and proxies for the other labor share drivers identified in the literature, such as technological progress and international trade.

Our key finding is that job protection deregulation reduces labor shares. In the countrylevel analysis, we find a major reform that liberalizes EPL to reduce the aggregate labor share by 0.6 to 0.8 percentage point, on average, over the medium term. In the country-industry-level analysis, the effect of that same reform is about 0.9 percentage point higher in high layoff-rate industries (defined as those in the $75^{\text {th }}$ percentile of the cross-industry distribution of layoff rates in the United States) compared with their low layoff-rate counterparts (those in the $25^{\text {th }}$ percentile). ${ }^{1}$ The differential medium-term effect between industries with low and high elasticity of substitution between capital and labor (defined as those in the $25^{\text {th }}$ and $75^{\text {th }}$ percentiles of the cross-industry distribution of elasticities) is larger, at 1.5 percentage point. We also find these effects to be mainly driven by a decline in the real wage; this further supports our interpretation that weaker bargaining power has been the key channel through which EPL deregulation has lowered labor shares in reforming advanced economies.

Using both our country-level and industry-level estimates, we perform an illustrative backof-the-envelope calculation of the impact of all past EPL reforms, both liberalizing and tightening ones, on the labor share. This exercise suggests a non-trivial impact; job protection deregulation may have contributed about 15 percent to the overall labor share decline. This reflects primarily the deregulation wave of the 1990s and 2000s, which is also the period over which labor shares declined the most in advanced economies.

\footnotetext{
${ }^{1}$ Following Bassanini et al. (2009), we use industry layoff rates computed from U.S. data to proxy for "natural" layoff rates as in the U.S. contracts can normally be terminated at will. Hence, this country is the closest to a frictionless economy. For more details, see Section III.
} 
Our paper relates to the extensive empirical literature on the drivers of labor shares which, somewhat surprisingly, has touched very little on the role of labor market regulation. Some papers study the impact of other drivers of labor shares, notably international trade and offshoring, via their effect on workers' bargaining power (see e.g. Kramarz, 2016, and the recent review by Hummels et al., 2016). Instead, our focus is on the direct role of labor market institutions. Blanchard (1997) and Blanchard and Giavazzi (2003) provide theoretical support for a link between labor market deregulation, weaker bargaining power and lower labor shares, and argue that such link is consistent with the decline observed across European countries during the 1990s. They also make a distinction between the short- and long-term effects. They do not provide any formal evidence, however.

The few empirical studies that attempt to quantify the impact of labor market institutions on the labor share have typically failed to find any significant effect. Using cross-country industry-level data, Bentolila and Saint-Paul (2003) explore a range of labor share drivers, including the frequency of labor conflicts, which they take as a proxy for workers' bargaining power. They find this variable to be insignificant, in a simple OLS regression without fixed effects. Elsby et al. (2013) exploit variation in the rate of unionization across US industries but do not find a significant association with the labor share. Checchi and Garcia-Penalosa (2008) explore the impact on labor shares of several labor market institutions in a cross-country timeseries set-up covering 16 OECD countries over the 1960-2000 period, but they do not consider EPL. Deakin et al. (2014) analyze the impact of EPL in an error correction framework for six OECD countries over 1970-2010 and do not find any statistically significant effect. Our sharper identification strategy — using a three-dimensional set-up with a rich set of fixed effects and two identification assumptions à la Rajan-Zingales (1998) drawn from theory-and reliance on a new dataset of major job protection reforms is what radically distinguishes our analysis from these earlier contributions.

Our paper also relates to the extensive empirical literature on the macroeconomic effects of job protection legislation on economic outcomes, which has primarily focused on productivity and employment. While not fully settled, the bulk of the evidence suggests that stringent regulation lowers productivity by distorting job turnover, and may also lower employment (for a comprehensive review, see e.g. OECD, 2013). However, except for the few studies mentioned earlier, this literature has not explored the impact of job protection on labor 
shares. Our paper fills this gap, thereby complementing recent research that has documented the macroeconomic effects from these and other labor market reforms.

The remainder of this paper is organized as follows. Section II discusses two stylized wage bargaining models to help guide our empirical strategy. Section III presents our new dataset of major employment legislation reforms, it illustrates the derivation of the layoff rates and elasticities of substitution that are used for the identification, and it provides some stylized facts concerning the decline of labor shares around EPL reform episodes. Section IV sets up the econometric framework. In Section V, we present the main regression results and perform several sensitivity analyses. Section VI contains some extensions, including back-to-the envelope calculations of the contribution of EPL reforms to the observed decline in labor shares. Section VII concludes.

\section{TheORETICAL FRAMEWORK}

To illustrate the theoretical impact of employment protection deregulation on the labor share and motivate our empirical approach, we use two stylized wage bargaining models - the Rightto-Manage and the Efficient Bargaining models (see e.g. Blanchard and Fischer, 1989). For ease of exposure, and following others, such as for example Blanchard and Giavazzi (2003), we assume that EPL deregulation directly weakens workers' bargaining power. For the rest, our theoretical analysis largely follows Bentolila and Saint-Paul (2003).

\section{A. Competitive Labor Market}

As a start, let's consider the case of a fully competitive labor market where labor is paid its marginal product. We assume that real output $\mathrm{Y}$ is produced using a constant elasticity of substitution (CES) production function with constant returns to scale:

$$
Y=F(K, A L)=\left(\alpha(K)^{\varepsilon}+(1-\alpha)(A L)^{\varepsilon}\right)^{1 / \varepsilon}
$$


where $K, L$ and $A$ denote capital, labor and labor-augmenting technical change, respectively, while the parameter $\varepsilon$ relates to the elasticity of substitution, $\sigma$, according to: $\sigma=1 /(1-\varepsilon){ }^{2}$

Defining the labor-to-capital ratio in effective units as $l \equiv \frac{A L}{K}$, rewriting $F(K, A L)=$ $K f\left(\frac{A L}{K}\right)$, and using that in competitive markets labor is paid its marginal product-such that $\frac{w}{p}=A f^{\prime}(l)$, where $w$ is the nominal wage and $p$ the price level—we can write the labor share as:

$$
L S=\frac{w L}{p Y}=l \frac{f \prime(l)}{f(l)}=\frac{(1-\alpha)(A L)^{\varepsilon}}{\alpha(K)^{\varepsilon}+(1-\alpha)(A L)^{\varepsilon}}
$$

For reasons that will become clear below, we want to express the labor share in terms of the capital-to-output ratio, $k$, which is $k=\frac{K}{\left(\alpha(K)^{\varepsilon}+(1-\alpha)(A L)^{\varepsilon}\right)^{1 / \varepsilon}}$. After simple manipulations, we can rewrite Equation (1) as:

$$
L S=1-\alpha k^{\varepsilon}
$$

The key insight from Equation (2) is that when labor is paid its marginal product, any change in factor prices and/or quantities affects the labor share only through its effects on the capitalto-output ratio $k$.

\section{B. Bargaining Under the Right-to-Manage Model}

To study the effects of EPL reforms on the labor share, we now introduce labor market frictions in the form of bargaining between employers and workers. We start by assuming that employers and workers first bargain over the wage, with employers then setting employment taking the wage as given. In this case, it remains optimal for employers to set employment such that labor is paid its marginal product, that is $\frac{w}{p}=A f^{\prime}(l)$. Equation (2) still holds.

What happens when easing EPL? Lower protection reduces workers' bargaining power, which in turn results in a lower wage. Employers respond by substituting labor for capital, and

\footnotetext{
${ }^{2}$ The analysis in this section does not depend on any particular assumption regarding the form of technical change. The key findings would be unchanged if we assumed Hicks-neutral, labor-, or capital-augmenting technological progress.
} 
therefore the capital-to-output ratio decreases. This drives a change in the labor share, whose sign depends on whether capital and labor are complements $(\varepsilon<0)$ or substitutes $(\varepsilon>0)$. To see this formally, take the derivative of the labor share expression in Equation (2) with respect to workers' bargaining power $\theta$ :

$$
\frac{\partial L S}{\partial \theta}=-\alpha \varepsilon k^{\varepsilon-1} \frac{\partial k}{\partial \theta}=> \begin{cases}>0 & \text { if } \varepsilon<0 \\ <0 & \text { if } \varepsilon>0\end{cases}
$$

where the inequalities follow from the fact that $\frac{\partial k}{\partial \theta}>0$.

Equation (3) shows that under the Right-to-Manage model, EPL deregulation that reduces workers' bargaining power $(\theta \downarrow)$ will lower the labor share if capital and labor are relative complements $(\varepsilon<0)$ but increase it if they are substitutes $(\varepsilon>0)$.

\section{Efficient Bargaining}

Under efficient bargaining, firms and workers instead bargain over both employment and wages. They set employment efficiently by equalizing the marginal product of labor to its opportunity cost, which is the workers' reservation wage. The wage itself is a weighted average of the average and marginal products of labor, with the weight on the former reflecting the bargaining power of workers. Formally, under Nash bargaining the real wage follows:

$$
\frac{w}{p}=\theta A \frac{f(l)}{l}+(1-\theta) A f^{\prime}(l)
$$

In this setting labor is paid more than its marginal product and Equation (2) does not longer hold. Recalling the definitions of $l$ and $k$, it can be easily shown that:

$$
L S=1-\alpha(1-\theta) k^{\varepsilon}
$$

EPL deregulation then reduces workers' bargaining power and the real wage, but employment does not change since it is pinned down by the efficient bargaining condition that links the marginal product of labor to the reservation wage. Therefore, the labor share unambiguously declines - regardless of the elasticity of substitution between labor and capital. Formally:

$$
\frac{\partial L S}{\partial \theta}=-\varepsilon \alpha(1-\theta) k^{\varepsilon-1} \frac{\partial k}{\partial \theta}+\alpha k^{\varepsilon}=\alpha k^{\varepsilon}>0
$$


using $\frac{\partial k}{\partial \theta}=0$, which in turn reflects the fact that changes in workers' bargaining leave unchanged the capital-to-output ratio due to the efficient bargaining condition.

\section{Implications for the Empirical Analysis}

Some of the insights from these two stylized models are similar. For example, in both cases, lower workers bargaining power unambiguously reduces the labor share if labor and capital are relative complements. Other predictions vary, particularly regarding whether lower bargaining power always reduces the labor share.

In practice, actual bargaining may combine elements of both models. The Right-to-Manage model has been regarded as describing rather well the actual functioning of labor markets in most European countries (see for instance Layard et al., 1991). At the same time, it has been argued that unions still play a part in determining the employment level, such that actual bargaining mixes up elements of both the right-to-manage and efficient bargaining modelssee, among others, the theoretical contribution of Manning (1987). This leads Cahuc et al. (2014), for example, to conclude that the right-to-manage and efficient bargaining models may ultimately "represent limit cases of the same model" (page 441).

Insofar as EPL increases worker bargaining power, the key implication for our empirical analysis is that deregulation is more likely to lower the labor share in countries and/or industries where capital and labor are less substitutable. In the next sections, we take these insights to the data.

\section{Dataset}

In this Section we describe the data used in the empirical analysis. We start by illustrating the dataset of EPL reforms episodes that are the focus of the analysis. Next, we discuss the derivation of the layoff rates and the estimation of the elasticities of substitution. The Section proceeds presenting the labor share and remaining data and it concludes providing some key stylized facts regarding the evolution of the labor share over the 1970-2015 period, with major emphasis on its behavior around EPL reform episodes. 


\section{A. Employment Protection Legislation Reforms}

Major reforms to EPL are identified by examining legislative and regulatory actions reported in all available OECD Economic Surveys, as well as additional country-specific sources, for 26 advanced economies over the 1970-2013 period (for details, see Duval et al., 2018). ${ }^{3}$ This methodology is related to the "narrative approach" used by Romer and Romer (1989, 2004, 2010, and 2017) and Devries et al. (2011) to identify monetary and fiscal shocks and periods of high financial distress.

In a first step, over 100 legislative and regulatory actions related to EPL are identified. In a second step, such actions are classified as major liberalizing or tightening reforms if one of the following three alternative criteria is met: (i) the OECD Economic Survey uses strong normative language to define the action; (ii) the policy action is mentioned repeatedly across different editions of the Survey; or (iii) the OECD EPL indicator is in the $5^{\text {th }}$ percentile of the distribution of the absolute changes in the indicator-or it would be if the OECD's scoring system were applied, but no OECD EPL indicator score is available for the country and year considered. When only the third condition is met, an extensive search through other available domestic and national sources is performed to identify the precise policy action underpinning the change in the indicator. Following this process, a variable is constructed that, for each country, takes value 0 in non-reform years, 1 in liberalizing reform years, and -1 in tightening reform years. Table A1.1 in Appendix 1 lists all reforms and tightening reforms identified in this way, while Figure A1.1 shows the distribution of reforms over time.

An important advantage of this approach vis-à-vis other existing databases (such as the European commission Labref, the Fondazione Rodolfo de Benedetti-IZA, and the ILO- EPLex database), is that it identifies major legislative reforms as opposed to just a long list of actions that in some cases would be expected to have little or no bearing on macroeconomic outcomes. Likewise, compared with an alternative approach that would infer major reforms from large changes in existing EPL indicators produced by the OECD, we have a longer time-series

\footnotetext{
${ }^{3}$ The 26 countries covered are: Australia, Austria, Belgium, Canada, Czech Republic, Denmark, Finland, France, Germany, Greece, Iceland, Ireland, Italy, Japan, Korea, Luxembourg, Netherlands, New Zealand, Norway, Portugal, Slovak Republic, Spain, Sweden, Switzerland, United Kingdom and United States.
} 
coverage - starting in 1970 rather than 1988 - and document precisely the timing of each action. These features are particularly useful for our empirical analysis that seeks to identify the dynamic effects of reforms.

The major strengths of this narrative database come with one limitation; because two large EPL reforms can involve different specific actions (for example, a major simplification of the procedures for individual and collective dismissals, respectively), only the average impact across major historical reforms can be estimated.

\section{B. Layoff Rates}

To identify the effect of reforms at the industry level, we derive industry-specific measures of layoff rates. To compute those, we closely follow the approach of Bassanini et al. (2009), which in turn builds on Micco and Pagés (2006), and define them as the percentage ratio of laid-off workers over total wage and salary employment. Differently from Bassanini et al. (2009), our rates are computed to match the ISIC Rev. 4 industry classification (the one used in the 2017 EU KLEMS database). To this purpose, we use data contained in the 2014 Displaced Workers Survey (DWS), conducted in the context of the more comprehensive IPUMS-CPS (see Flood et al., 2017). ${ }^{4}$ We use U.S. data given that employment protection legislation is essentially non-existent there. Hence, the U.S. is the closest empirical example of a frictionless economy in which employers can freely adjust the workforce in response to operational needs. Appendix 2 describes in detail the construction of US layoff rates. Table A2.1 lists the layoff rate for each industry in the sample. The industry with highest layoff rate is "Electrical \& Optical", while that with the lowest is "Coke \& Refined Petroleum".

\section{Elasticities of Substitution}

While several papers provide estimates of the EOS for the aggregate economy, fewer focus on the industry level, and to our knowledge none does so for the ISIC Rev 4 industry classification,

\footnotetext{
${ }^{4}$ Bassanini et al. (2009) construct U.S. layoff rates using data contained in the 2004 CPS Displaced Workers Supplement for 22 industries classified to match the classification used in the EU KLEMS 2007 database (ISIC Rev. 3 classification).
} 
which is the one we use (see III.D). Therefore, we derive industry-specific elasticities of substitution (EOS) following standard practice in the literature, estimating the structural parameter directly from the solution to the firm's profit maximization problem (see, among others, Berndt, 1976, and Antràs, 2004).

In particular, we infer industry-specific EOS by estimating the following equation:

$$
\ln \left(\frac{P_{j, t}^{K}}{P_{j, t}}\right)=\ln \left(\alpha_{j}\right)+\frac{1}{\sigma} \ln \left(\frac{F_{j, t}\left(K_{j, t} L_{j, t}\right)}{K_{j, t}}\right)+\epsilon_{j, t}
$$

where $P^{K}$ is the price of capital services; $P$ is the price of the aggregate output $F(K, L) ; K$ and $L$, are capital and labor services and $\sigma$ is the elasticity of substitutions. Appendix 3 provides details on the estimation, as well as alternative measure of EOS that will be used as robustness checks. Table A3.1 lists the EOS for each industry in the sample. The average is about 0.7, with the EOS varying between 0.3 ("Construction") and 1.5 ("Telecommunications"). Overall, our estimates are in line with those of Antràs (2004), Oberfield and Raval (2014) and Lawrence (2015). Using different methodologies and data, these authors found the average EOS in the U.S. to be well below unity.

\section{Labor Share and Other Data}

Country-level time series of labor shares are taken from the OECD Analytical Database. These data cover an unbalanced set of 26 advanced economies from 1970 to 2015. To derive industrycountry labor shares, we use harmonized data on value added and labor compensation as contained in the EU KLEMS databases. To maximize the country-coverage we use data from both the 2017 release (see Jäger, 2017) and the 2012 release (see O'Mahony and Timmer, 2009). ${ }^{5}$ Overall, for the country-industry-time level analysis, we have an unbalanced panel comprising 32 industries in 22 advanced economies from 1970 to $2015 .{ }^{6}$ Mean values of labor

\footnotetext{
${ }^{5}$ The EUKLEMS database provides data on added value and labor compensation in 34 industries, classified according to the ISIC Rev. 4 classification. Next, we define the labor share as the percentage ratio of labor compensation relative to added value. We drop 2 industries from the sample, namely activity of households as employers and activities of extraterritorial organizations and bodies, as for most countries labor compensation and/or added value data are not available.

${ }^{6}$ The countries for which industry-level data are not available are Iceland, New Zealand, Norway and Switzerland.
} 
shares and value-added shares, together with the layoff rates and estimated EOS used for the baseline analyses, are reported in Table A4.1 of Appendix 4.

Whereas we present stylized facts for all the 32 industries, our baseline empirical analysis does not cover those that typically belong to the public sector, and it also excludes the agriculture and the construction industries. To motivate this choice, we observe that special EPL provisions typically apply to civil and public servants as well as seafarers. ${ }^{7}$ Moreover, EPL generally does not apply to seasonal workers, who account for a sizable share of overall employment in the agriculture and construction industries. We also exclude from the analysis the (i) Coke, Refined Petroleum and Nuclear Fuel, and the (ii) Other Manufacturing industries due to potential issues in the measurement of added value. In a sensitivity analysis we show that our baseline results do not hinge on the exclusion of these two industries.

To verify that our results are consistent with a reform-driven decline in worker bargaining power and real wages, we construct a measure of the real wage using data on average hourly earnings and hours worked (from the EU KLEMS database) as well as on the price level (from the IMF World Economic Outlook database).

All specifications control for major reforms of EPL for temporary workers, which are identified following strictly the same approach used to construct our dataset of major reforms of EPL for regular workers (for details, see Duval et al., 2018). For robustness checks, we collect further data to be used as additional controls. Two variables capture the roles of technological change and globalization, which feature prominently in the recent literature on labor share drivers. Specifically, we proxy for openness to trade and technological change using respectively the ratio of imports and exports to GDP and the price of investment goods relative to output (both sourced from the Penn World Tables, version 9.0, see Feenstra et al., 2015). Moreover, since current and expected GDP growth rates could correlate with both EPL reforms and labor shares, we also control for them, using data from the OECD Economic Outlook (Fall issue). Finally, we control for trade union density, which we take from the OECD and the ICTWSS database (Visser, 2016).

\footnotetext{
${ }^{7}$ Among the countries covered in our analysis EPL for public and civil servants is governed by special laws in the following ones: Austria, Belgium, Czech Republic, Denmark, Finland, France, Germany, Greece, Italy, Japan, Korea, Luxembourg, Portugal, Slovakia, Spain and the United States. For more information, see the ILO EPLex database (http://www.ilo.org/dyn/eplex/termmain.home).
} 


\section{E. Stylized Facts}

Appendix 5 discusses some stylized facts about the evolution of labor shares over the period 1970-2015. ${ }^{8}$ Three stand out. First, labor shares have generally been on a declining trend since the mid-1970s, with the decline accelerating in the 1990s. Second, there exist significant heterogeneities both across countries and industries. Third, about 70 percent of the decline in country-level labor shares can be accounted by within-industry changes.

Most importantly in the context of this paper, the decline in the labor share has been typically larger in periods following EPL reforms. To document this, we start by noting that liberalizing reforms were predominantly implemented during the 1990s and the 2000s, which is also the period over which the labor share declined the most (see Figure A5.1 in Appendix 5). Then, in Figure 1 we compare the mean cumulative change in country labor shares in the years before and after any EPL reform in reforming countries (green solid bars) versus nonreforming countries (red bars). Before EPL reforms, labor shares had typically been on a declining trend whose slope was similar between reforming and non-reforming countries. This gives us some comfort about the exogeneity of our reform episodes to labor share trends at the country level. Crucially, the decline accelerated following EPL deregulation, while it did not in non-reforming countries.

To check whether the decline in the labor share in the aftermath of EPL reforms displayed some heterogeneity across industries, we repeat the same analysis for within-industry labor shares by splitting the sample according to industry characteristics (Figure 2). Panel A (B) of Figure 2 shows the mean cumulative change in the labor share before and after EPL reforms for industries in the lower (upper) quartile of the distribution of US layoff rates. Panel C (D) shows the same statistics, but for industries in the lower (upper) quartile of the distribution of EOS. In line with priors, the decline in labor shares following EPL reforms observed at the macro level appears to be driven by industries with higher layoff rates and higher relative complementarity between capital and labor. This is reassuring about the identification strategy

\footnotetext{
${ }^{8}$ Since most of our stylized facts rely on data at the country-industry level, for consistency this section focuses on the 22-country sample for which such data are available. Country-level stylized facts for our full sample of 26 countries are available upon request.
} 
that we adopt to establish the causal effects of labor market deregulation on labor shares, which we explain more in detail in the next Section.

\section{ECONOMETRIC FRAMEWORK}

To estimate the dynamic response of labor shares to EPL reforms, we employ the local projection method proposed by Jordà (2005) to derive impulse-response functions (IRFs). This approach has been advocated by Auerbach and Gorodnichenko (2013) and Romer and Romer (2017), among others, as a flexible alternative to vector autoregression (autoregressive distributed lag) specifications since it does not impose dynamic restrictions and it is better suited to estimate nonlinearities in the dynamic response.

Starting with the country analysis, we estimate the following equation for each response horizon $k=0, . ., 5$ :

$y_{j, t+k}-y_{j, t-1}=\alpha_{j}+\gamma_{t}+\beta_{k} R_{j, t}+\theta X_{j, t}+\sum_{h=1}^{k}\left(\varphi_{h} R_{j, t+h}\right)+\sum_{l=1}^{L}\left(\delta_{l} \Delta y_{j, t-l}+\gamma_{l} R_{j, t-l}\right)+\epsilon_{j, t}$

in which $j$ and $t$ denote country and time; $y$ is the labor share of income; $\beta_{k}$ denotes its response at each horizon (year) $k$ after the reform; $\alpha_{j}$ are country fixed effects, included to take account of differences in countries' invariant characteristics; $\gamma_{t}$ are time fixed effects, included to take account of global shocks; $R_{j, t}$ is our EPL reform variable, which takes value 0 in non-reform years, 1 in liberalizing reform years and -1 in tightening reform years; and $X_{j, t}$ is a set a of control variables; and $\Delta$ denotes the first difference operator.

Equation (8) includes forward reform dummies $\left(\sum_{h=1}^{k} R_{j, t+h}\right)$. This is to control for reforms that happen within the response horizon $t+k$ (for $k>1$ ) that are not captured by $R_{j, t}$. As shown by Teulings and Zubanov (2014), not doing so would leave the model misspecified and bias our estimates. In our context, this is particularly important since EPL reforms are sometimes adopted in sequence or, in a few cases, reversed after several years.

We also include recession dummies and dummies capturing reforms to temporary contracts. The former aim to address possible omitted variable bias that could stem from the fact that economic conditions may shape the likelihood of reform, as suggested by the "crisisinduces-reform" hypothesis (Drazen and Easterly, 2001; Tommasi and Velasco, 1996), while the latter attempt to control for potential contemporaneous reforms that may also influence the 
labor share. In a sensitivity analysis, we add further controls, including, among others, trade openness and the relative price of investment goods, which have been put forward as prominent drivers of labor share trends in advanced economies (Karabarbounis and Neiman, 2014; Elsby et al., 2013; IMF 2017). We find our results to be unaffected, reflecting that major EPL reforms are not correlated with these drivers. The empirical specification is completed by two lags of the 1-period labor share change and of the EPL reform dummy. As shown in the robustness checks, the results are robust to different lag specifications.

Equation (8) is estimated using OLS. IRFs are obtained by plotting the $\beta_{k}$ coefficients for $k=0, . ., 5$, with 90 percent confidence bands computed using the standard deviations associated with the estimated coefficients $\beta_{k}$ - based on clustered robust standard errors. ${ }^{9}$

Next, to minimize any endogeneity concerns and explore the channels through which EPL reforms affect the labor share of income, we turn to country-industry-level analysis, using a differences-in-differences identification strategy in the spirit of Rajan and Zingales (1998). Specifically, we estimate the following equation:

$$
\begin{aligned}
& \quad y_{i, j, t+k}-y_{i, j, t-1}=\alpha_{j, t}+\gamma_{i, j}+\mu_{i, t}+\beta_{k} \vartheta_{i} R_{j, t}+\theta \mathrm{X}_{i, j, t}+\sum_{h=1}^{k}\left(\varphi_{h} \vartheta_{i} R_{j, t+h}\right)+ \\
& +\sum_{l=1}^{L}\left(\delta_{l} \Delta y_{i, j, t-l}+\gamma_{l} \vartheta_{i} R_{j, t-l}\right)+\epsilon_{i, j, t}
\end{aligned}
$$

in which $y_{i, j, t+k}$ is the labor share in industry $i$ of country $j$ in period $t+k ; \alpha_{j, t}$ are country-time fixed effects, which control for any variation that is common to all industries of a country's economy, such as country-wide macroeconomic shocks and reforms in other (non-EPL) areas; $\gamma_{i, j}$ are country-industry fixed effects, included to take account of cross-sectional differences in average changes in country-industry labor shares; $\mu_{i, t}$ are industry-time fixed effects that control for different labor share changes across industries; $R_{j, t}$ is our EPL reform variable; $\vartheta_{i}$ are industry-specific characteristics, discussed below, which we use to identify the causal effects of EPL reform on the (country-industry-level) labor share; $X_{i, j, t}$ is a set of control variables including a temporary contracts reform dummy plus, in a sensitivity analysis, other

\footnotetext{
${ }^{9}$ Another advantage of the local projection method compared to vector autoregression (autoregressive distributed lag) specifications is that the computation of confidence bands does not require Monte Carlo simulations or asymptotic approximations. One limitation, however, is that confidence bands at longer horizons tend to be wider than those estimated in vector autoregression specifications.
} 
labor share drivers. All controls are interacted with industry-specific characteristics $\vartheta_{i}$. As in the country-level analysis, we include forward reform dummies (see Teulings and Zubanov, 2014) as well as two lags of the first-difference of $y_{i, j, t}$ and of $R_{j, t}$.

This differences-in-differences specification relies on two alternative identification assumptions. The first is that stringent dismissal regulations are more binding, and therefore raise workers' bargaining power more, in industries characterized by a higher "natural" propensity to adjust their workforce - that is, a higher "natural" layoff rate. The second identifying assumption follows from our theoretical framework and suggests that job protection deregulation is likely to reduce the labor share more in industries where capital and labor are less substitutable. Hence, we estimate Equation (9) using three alternative industry specific characteristics, $\vartheta_{i}$ : (i) the "natural" layoff rate; (ii) $1-\varepsilon$, the inverse of the EOS (1$\varepsilon=1 / \sigma$ ); and (iii) the interaction between these two, because the lower the EOS is, the more deregulation should reduce the labor share in industries where EPL is more binding. Since we include country-year dummies, which control for aggregate effects, our results should be interpreted as the cross-industry differential effects.

Equation (9) is estimated with OLS for each $k=0, \ldots, 5$. Similar to the country-level analysis, IRFs and the associated confidence bands are computed using the coefficients $\beta_{k}$, and the respective standard errors. These are clustered at the country-industry level and, for the identifications relying on (i) the EOS and (ii) the interaction between EOS and the layoff rates, they are obtained through bootstrapping. ${ }^{10}$ The inclusion of the rich set of fixed effects and controls should largely address endogeneity concerns related to omitted variable bias. In addition, reverse causality is unlikely to be a concern in our set-up. First, the natural propensity to layoff in the U.S. is arguably orthogonal to industry-level labor share changes in other countries. A similar argument holds for the EOS between capital and labor. Second, it is highly unlikely that industry-level labor share patterns can influence EPL reform. Movements in the labor share at the aggregate level may well do so, but this potential source of reverse causality is addressed through the inclusion of country-time fixed effects. In other words, claiming

10 When we estimate Equation (9) using the EOS and the interaction between EOS and layoff rates as identification variables the regressor are derived from estimated variables themselves and standard t-statistics may be biased upwards. Hence, we compute standard errors via bootstrapping method (with 500 replications). However, our results are robust to not using bootstrapped standard errors. 
reverse causality would mean arguing that differences in labor share changes across industries lead to economy-wide EPL reforms - this, we argue, is implausible.

\section{Baseline Results And Robustness Checks}

\section{A. Country-level Analysis}

Figure 3 shows the estimated dynamic response of the labor share to a liberalizing EPL reform over the five-year period following implementation, together with the 90 percent confidence interval around the point estimate. Major deregulation episodes have a statistically significant and persistent negative effect on the labor share. This effect reaches 0.8 percentage point two years after the reform, before declining marginally to 0.6 percentage point — it eventually levels off at this level eight years after the reform. ${ }^{11}$

\section{Robustness checks}

To check the sensitivity of these results to potential sources of endogeneity, we estimate two additional specifications with a richer set of control variables. First, we control for factors that have been put forward as key forces behind the trend labor share decline in advanced economies, namely technological progress and international trade, as well as other potential drivers such as changes in trade union density. Second, we also estimate a specification including past GDP growth as well as expected future GDP growth between periods $t$ and $t+k$ - the horizon over which the impulse response functions are computed - at time $t$ - 1 . Table 1 summarizes the results from these two robustness checks; they turn out to be very similar to, and do not statistically differ from, our baseline, suggesting that the potential sources of endogeneity listed above are not empirically important in practice.

\section{B. Country-industry Level Analysis}

Figure 4 presents the results from the country-industry analysis, that is, from estimating Equation (9). Panels A, B and C show the IRFs when the effect of the reform is identified,

\footnotetext{
${ }^{11} \mathrm{We}$ also separately estimated the effect of liberalizing and tightening EPL reforms. As expected, the magnitude of the estimated response is similar (although of opposite sign). This indicates that our results are not driven by tightening reform episodes.
} 
respectively, through the layoff rates, the EOS and the interaction between these two. The results are qualitatively similar across all specifications, indicating a relative decline in the labor share in high layoff rates and low substitutability industries. They are also quantitatively larger when we identify the reform using both the layoff rates and the EOS, which is our preferred specification.

Panel A shows that over the medium term-five years after the reform takes place-job protection deregulation tends to reduce the labor share in industries with a high layoff rate relative to those with a low-layoff-rate. The differential medium-term reduction in the labor share following an EPL reform between an industry with a relatively high natural layoff rate (at the $75^{\text {th }}$ percentile of the cross-industry distribution of layoff rates in the U.S) and one with a relatively low natural layoff rate (at the $25^{\text {th }}$ percentile of the distribution) is about 0.9 percentage point.

In line with theory, the results also suggest that the effect of EPL reforms on the labor share tends to be larger in industries with a lower EOS between capital and labor (Panel B). The differential medium-term reduction in the labor share between an industry with a relatively low EOS (at the $25^{\text {th }}$ percentile of the $\varepsilon$ 's distribution) and one with a relatively high EOS (at the $75^{\text {th }}$ percentile of the $\varepsilon$ 's distribution) is about 1.5 percentage point.

Finally, and as expected, the identification through the interaction between the natural layoff rate and the EOS yields the largest and sharpest estimate of the differential impact of EPL reforms across industries (Panel C). In short, the effect tends to be larger in industries with a higher natural layoff rate and a lower elasticity of substitution. Quantitatively, the joint effect of moving from the $25^{\text {th }}$ to the $75^{\text {th }}$ percentile of the layoff rate and from the $75^{\text {th }}$ to the $25^{\text {th }}$ percentile of the EOS' distribution is about -1.7 percentage point 5 years following a liberalizing EPL reform. Except upon impact, the effect is statistically significant over the entire horizon considered.

\section{Robustness checks}

We now check the sensitivity of our results to several different specifications. We start by checking that our estimates do not depend on the chosen lag structure and estimate the model 
employing in turn, 1, 3 and 4 lags (Table 2). In Table 2 we also show that the results do not hinge on the inclusion of the forward reform dummies. Next, we verify that our findings are not driven by any given country or industry. To do so we estimate Equation (9) excluding first one country and then one industry at a time. Figures 5 and 6 report the corresponding impulse responses, together with the baseline estimates and relative confidence bands. All the newly obtained impulse responses lie close to the baseline and always fall within its confidence bands.

Since the data we used for the labor share comes from two different vintages of the EU KLEMS database, there might be statistical differences across them. Therefore, we verify that our results hold when only the latest version is used (Table 3). In Table 3 we also illustrate that the baseline estimates do not depend on the exclusion of the Coke, Refined Petroleum and Nuclear Fuel, and the Other Manufacturing industries. Finally, exploiting that the EPL reforms we analyze generally do not apply to the public sector, agriculture and construction, we estimate an alternative specification in which these industries are used as a control group by setting $\vartheta_{i} R_{j, t}$ to 0 for them. In line with our expectation, the results point to even larger differential effects across industries (Table 3).

The distribution of industries according to natural layoff rates relies on US layoff rates that might be imprecisely estimated. To address this potential concern, we rerun the specifications that rely on the layoff rates for the identification using an alternative measure. Specifically, we divide industries in two categories depending on whether their layoff was above the median in all the three years covered by the 2014 Displaced Workers Survey (see Table A2.1), and construct a dummy variable that takes value 1 (0) for industries in which EPL is (is not) binding. According to this rather conservative classification, EPL only binds in seven industries, and in equal manner across them. In another robustness check, we use the layoff rates calculated for the year 2013 instead of the average over 2011-2013. The impulse responses obtained using these alternative measures, reported in Table 4, are qualitatively similar to the baseline results. When the dummy variable is used, the estimated coefficients of the reform variable are quantitatively lower than in our baseline, but they cannot be readily compared. Importantly, when our preferred identification strategy based on the interaction between layoff rates and EOS is used, the negative impact of EPL reforms on the labor share is statistically significant at least form the third year onward in all cases. 
We also run a sensitivity analysis on our measure of the EOS between labor and capital, re-estimating our specifications using the alternative sets of EOS discussed in Appendix 3. We employ in turn the EOS estimated (i) using data on the real capital stock as a proxy for capital services, (ii) using the nominal capital stock divided by capital services to proxy for the rental rate of capital, and (iii) relaxing the assumption of Hicks-neutral technical change. The results, presented in Table 5, are very similar to our baseline results. Again, they are most statistically significant when using our preferred identification strategy based on the interaction between layoff rates and EOS.

Another possible concern with an OLS estimation of Equation (9) might be that the results could be biased due to the omission of other macroeconomic developments that may affect industry-level labor shares through their interaction with industry-specific natural layoff rates or/and the elasticities of substitution, and that may at the same time correlate with EPL reforms. A candidate is the change in union density, whose trend decline may have reduced workers' bargaining power and affected the labor share through the same channels as EPL reforms. While changes in union density are not correlated with EPL reforms - the correlation is only 0.01 - we nonetheless check the robustness of our results by adding to Equation (9) an interaction term between the change in union density and the industry-specific natural layoff rate (or/and the elasticity of substitution).

Likewise, while the effects of technological progress-proxied by the relative price of investment - and trade openness on labor shares are controlled for through country-time fixed effects, they could still be a source of omitted variable bias if (i) they were correlated with EPL reforms, and (ii) their impact varied with industry-specific characteristics. Therefore, we check the robustness of our results by also adding to Equation (9) the interaction of these variables with industry-specific characteristics. Table 6 shows the results from these sensitivity analyses. The effects of EPL reforms on country-industry labor shares when controlling for the additional factors described above are very close to, and not statistically different from, our baseline estimates. 


\section{EXTENSIONS}

\section{A. Channels}

What factors drive the negative response of the labor share to job protection deregulation? Wage bargaining models of the type we presented in Section II imply that, insofar as EPL reform reduces worker bargaining power, it should lower the real wage, all else equal. Implications for the capital-to-output ratio and the employment level are more ambiguous $a$ priori, as they depend on whether bargaining takes place only over the wage or also over employment.

As a cross-validation exercise, we test whether EPL reforms are also associated with a decline in the real wage. To this end, we re-estimate Equation (9) using as dependent variable the change of the (log) hourly real wage. Since there are no theoretical reasons to expect that the effect of deregulation on the real wage should depend on the elasticity of substitution, the identification relies exclusively on the layoff rate. We also apply the same approach to estimate the effect of deregulation on the employment level and the capital-to-output ratio.

Table 7 shows the estimated coefficients. In line with theoretical priors, EPL deregulation leads to a relative fall in the real wage in industries with a high natural layoff rate - where EPL is more binding and deregulation thus has a greater impact on worker bargaining powerrelative to those with a low rate. This negative differential effect between industries at the $75^{\text {th }}$ and $25^{\text {th }}$ percentiles of the layoff rate distribution gets larger over time, reaching about -1.5 percent four years after the reform (significant at the 5\% confidence level). Consistent with this finding, employment growth instead shows a positive differential response, which becomes significant two years following the reform. The capital-output ratio displays a negative medium-term response, although this is not significant at conventional confidence levels. Overall, these results are supportive of a significant role of bargaining power in driving the impact of EPL deregulation on the labor share, in line with our illustrative theoretical framework. 


\section{B. EOS Above Versus Below 1}

Our baseline specification does not allow for any switch in the sign of the impact of EPL reforms on the labor share depending on whether the EOS is above or instead below 1. This is because we did not want to tie our empirical strategy to the Right-to-Manage model — or any other specific wage bargaining model-since actual wage bargaining is likely to be more complex and combine elements from various models. Yet, if bargaining took place only over wages following the Right-to-Manage model, the sign of the impact of EPL deregulation on the labor share should depend strictly on whether capital and labor are relative complements or instead substitutes.

To test this formally, we split the sample in two according to whether the EOS is above or below 1 and run Equation (9) on the two restricted samples. For the identification we rely on the natural layoff rates. The results, presented in Table 8, are broadly in line with the Right-toManage model's predictions: relative to industries with a low natural layoff rate, those with a high layoff rate experience an increase in the labor share following a liberalizing EPL reform when the EOS above 1 (substitutability), and a drop if the EOS is below 1 (complementarity). Quantitatively, the effect of moving from the $25^{\text {th }}$ to the $75^{\text {th }}$ percentile of the layoff rate distribution among industries characterized by substitutability is significant already upon impact and reaches about +1.8 percentage point after 3 years, whereas the corresponding effect is negative and significant, at about -0.9 , in the sub-sample of industries with EOS below 1 . At longer horizons, the effect becomes statistically insignificant in the former group of industries (possibly owing to loss of statistical power due to the small sample), while it remains significant in the latter.

\section{Back-of-the Envelope Calculation of the Contribution of Job Protection Deregulation to the Overall Decline in Labor Shares}

To what extent does our estimated impact of EPL reforms on labor shares matter at the macroeconomic level? In this section, we perform a few back-of-the-envelope calculations to get a rough sense of the share of the overall decline in labor shares that may be ascribed to EPL deregulation, based on our estimates. 
In the country-level analysis, we found a major EPL liberalizing reform to cause the labor share to decline by about 0.6 percentage point over the four years following the reform. By calculating the net number of liberalizing reforms over the period considered for each country, we can compute an illustrative estimate of the overall impact of EPL deregulation on the change in the labor share. Taking a simple average of these estimates across countries, we find that deregulation may have accounted for about 14 percentage points of the overall labor share decline in advanced economies over 1970-2015.

Our figures implicitly assume that the labor share decline estimated over the four years following the reform persists in the long run. Indeed, this is what our analysis suggests if we extend its horizon beyond four years; in our baseline regression, the effect of EPL reforms is found to stabilize at about -0.8 percentage point after 8 years. Given that the magnitude of the trend decline in the labor share depends on the period considered, including on whether the end year falls within a recession or an expansion period (see e.g. Kehrig and Vincent, 2017), we also perform the same calculation over 1970-2007-thereby excluding the Great Recession - and 1990-2015 - the period over which the trend decline in the labor share was steepest. Remarkably in line with the overall estimate above, we find that changes in EPL contributed about 14 percent and 15 percent to the overall labor share decline over the 19702007 and 1990-2010 periods, respectively. Under a number of simplifying assumptions discussed in Appendix 6, similar back-of-the envelope calculations can be performed using our country-industry-level estimates. Reassuringly, these calculations which point to similar effects.

\section{CONCLUSION}

This paper explored the impact of job protection deregulation on labor shares using both country-time-level and country-industry-time-level data and a new dataset of major reforms of regular contracts covering 26 advanced economies over the past four decades. We applied the local projection method to estimate the dynamic response of labor shares at both the country and country-industry levels. For the latter analysis, we used two alternative identifying assumptions à la Rajan-Zingales (1998) derived from theory—namely that job protection 
reforms should have larger effects in industries characterized by a high "natural" propensity to regularly adjust their workforce and a low elasticity of substitution between capital and labor.

Unlike previous literature, we found a statistically and economically significant negative effect of weaker job protection on labor shares. In line with theory, this effect is concentrated in industries with a higher propensity to regularly adjust the workforce and a lower elasticity of substitution between capital and labor, and it is likely driven by a reduction in wage rents. To account for country-specific macroeconomic shocks and other aggregate drivers of labor shares, as well as for industry-specific developments, our country-industry-level analysis included country-time and industry-time fixed effects - and country-industry fixed effects as well. Our findings are also robust to a variety of alternative specifications controlling for potential omitted variable bias and reverse causality as well as including different deterministic components.

Our results call for more research on the role of labor market deregulation, alongside those of technology and globalization, in the extensive literature on the drivers of the decline in labor shares. On the policy front, they also point to the need for assessing the effects of labor market reform plans on a wide range of macroeconomic outcomes-including productivity, employment and output, but also wages and labor shares - and for addressing trade-offs between efficiency and equity when designing such reforms. 


\section{REFERENCES}

Acemoglu, Daron and Pascual Restrepo. 2016. "The Race Between Machine and Man: Implications of Technology for Growth, Factor Shares and Employment.” NBER Working Paper, May, No. 22252.

Alvarez-Cuadrado, Francisco, Ngo Van Long and Markus Poschke. 2015. "Capital-Labor Substitution, Structural Change and the Labor Income Share." IZA Discussion Paper, No. 8941, March

Antràs, Pol. 2004. "Is the U.S. Aggregate Production Function Cobb-Douglas? New Estimates of the Elasticity of Substitution." Contributions to Macroeconomics. Vol. 4, Issue 1, Article 4.

Auerbach, Alan. J. and Yuri Gorodnichencko. 2013. "Measuring the Output Responses of Fiscal Policy." American Economic Journal: Economic Policy. Vol. 4, No. 2, May: 1-27.

Autor, David, David Dorn, Lawrence F. Katz, Christina Patterson and John Van Reenen. 2017. "Concentrating on the Fall of the Labor Share." American Economic Review: Papers \& Proceedings, Vol. 107, No. 5: 180-185.

Baccianti, Claudio. 2013. "Estimation of Sectoral Elasticities of Substitution along the International Technology Frontier.” ZEW Discussion Paper, No. 13-092.

Barkai, Simcha. 2017. "Declining Labor and Capital Shares.” Job Market Paper.

Bassanini, Andrea, Luca Nunziata L and Danielle Venn. 2009. "Job protection legislation and productivity growth in OECD countries." Economic Policy, Vol. 24, April: 349-402.

Bentolila, Samuel and Gilles Saint-Paul. 2003. "Explaining Movements in the Labor Share." The B.E. Journal of Macroeconomics, Vol. 3, Issue 3, July: 1-33.

Berndt, Ernst R. 1976. "Reconciling Alternative Estimates of the Elasticity of Substitution." The Review of Economics and Statistics, Vol. 58, No. 1, February: 59-68

Blanchard, Olivier. 1997. "The Medium Run.” Brookings Paper on Economic Activity, Vol. 2: $89-158$.

Blanchard, Olivier and Stanley Fischer. 1989. "Lectures on Macroeconomics" The MIT Press, Book.

Blanchard, Olivier and Francesco Giavazzi. 2003. "Macroeconomic Effects of Regulaton and Deregulation in Goods and Labor Markets." Quarterly Journal of Economics, Vol. 118, Issue 3, August: 879-907. 
Boehm, Cristoph E., Aaron Flaaen and Nitya Pandalai-Nayar. 2017. "Multinationals, Offshoring, and the Decline of U.S. Manufacturing." Center for Economic Studies Research Paper, No. 17-22, February.

Bridgman, Benjamin. 2017. "Is Labor's Loss Capital's Gain? Gross versus Net Labor Shares." Macroeconomic Dynamics. July.

Cahuc, Pierre, Stephane Carcillo and Andre Zylberberg. 2014. Labor Economics, $2^{\text {nd }}$ Edition, Chapter 7. The MIT Press,Cambridge, Massachussets.

Checchi, Daniele and Cecilia Garcia Penalosa. 2008. "Labour Market Institutions and Income Inequality.” Economic Policy, Vol. 56: 601-649.

Dao, Mai Chi, Mitali Das, Zsoka Koczan, Weicheng Lian. 2017. "Why is Labor Receiving a Smaller Share of Global Income? Theory and Empirical Evidence.” IMF Working Paper, No. 17/169, July. Washington.

Devries, Pete, Jaime Guajardo, Daniel Leigh and Andrea Pescatori. 2011. "A New Actionbased Dataset of Fiscal Consolidation.” IMF Working Paper, No. 11/128, June. Washington.

Drazen, Allan, and William Easterly. 2001. "Do Crises Induce Reform? Simple Empirical Tests of Conventional Wisdom.” Economics and Politics, 13 (2), 129-157.

Duval, Romain, Davide Furceri, Bingjie Hu, Joao Jalles and Huy Nguyen. 2018. “A New Narrative Database of Product and Labor Market Reforms in Advanced Economies." IMF Working Paper, 18/19, January. Washington.

Eden, Maya and Paul Gaggl. 2015 "On the Welfare Implications of Automation.” World Bank Policy Research Working Paper, No. 7487, November. Washington

Elsby, Michael W. L., Bart Hobijn and Aysegul Sahin. 2013. "The Decline of the U.S. Labor Share.” Brookings Papers on Economic Activity, Fall: 1-63.

Feenstra, Robert C., Robert Inklaar and Marcel P. Timmer. 2015. "The Next Generation of the Penn World Table." American Economic Review, Vol. 105, No. 10: 3150-3182

Flood, Sarah, Miriam King, Steven Ruggles, and J. Robert Warren. 2017. "Integrated Public Use Microdata Series, Current Population Survey: Version 5.0.” Database. Minneapolis: University of Minnesota.

Furceri, Davide, Prakash Loungani and Jontahn D. Ostry. 2017. "The Aggregate and Distributional Effects of Financial Globalization: Evidence from Macro and Sectoral Data." Working Paper. 
Hummels, David, Jakob Munch and Chong Xiang. 2016. "Offshoring and Labor Markets." IZA Discussion Paper No. 9741, February.

International Monetary Fund (IMF). 2017. "Understanding the Downward Trend in Labor Income Shares." Chapter 3. World Economic Outlook April 2017: 121-172. Washington.

Jäger, Kirsten. 2017. "EU KLEMS Growth and Productivity Accounts 2017 Release, Statistical Module." The Conference Board.

Jordà, Òscar. 2005. "Estimation and Inference of Impulse Responses by Local Projections." American Economic Review. Vol. 95. No. 1: 161-82.

Jorgenson, Dale. 1963. "Capital Theory and Investment Behavior." American Economic Review, Vol. 53, No. 2, may: 247-259

Kaldor, Nicholas. 1957. "A Model of Economic Growth.” The Economic Journal, Vol. 67. No. 268, December: 591-624.

Kaldor, Nicholas. 1957. "Capital Accumulation and Economic Growth." In The Theory of Capital, ed. F. A. Lutz and D. C. Hague, 177-222. New York.

Karabarbounis, Loukas and Brent Neiman. 2014. "The Global Decline of the Labor Share." The Quarterly Journal of Economics, Vol. 129, Issue 1: 61-103.

Kehrig, Matthias and Nicolas Vincent. 2017. "Growing Productivity without Growing Wages: The Micro-Level Anatormy of the Aggregate Labor Share Decline.” CESifo Working Paper, No. 6554. Munich.

Koh, Dongya, Raul Santaeulalia-Llopis and Yu Zheng. 2016. "Labor Share Decline and Intellectual Property Products Capital.” Working Paper.

Kramarz, Francis. 2016. "Offshoring, Wages and Employment: Evidence from Data Matching Imports, Firms and Workers." Chapter 9 in Fontagne, Lionel and Ann Harrison (eds.), The Factory-Free Economy: Outsourcing, Servitization, and the Future of Industry, Oxford University Press, Oxford, United Kingdom.

Layard, Richard, Stephen Nickell and Richard Jackman. 1991. "Unemployment. Macroeconomic Performance and the Labour Market." Oxford University Press. Oxford.

Lawrence, Robert Z. 2015. "Recent Declines in Labor's Share in US Income: A Preliminary Neoclassical Account.” Peterson Institute Working Paper, No. 15-10. Washington.

Manning, Alan. 1987. “An Integration of Trade Union Models in a Sequential Bargaining Framework." The Economic Journal, Vol. 97, Issue 385: 121-139. 
Micco, Alejandro and Pagés, Carmen. 2006. "The Economic Effects of Employment Protection: Evidence from International Industry-Level Data.” IZA Discussion Paper No. 2433.

O’Mahony, Mary and Marcel P. Timmer. 2009. "Output, Input and Productivity Measures at the Industry Level: the EU KLEMS Database." The Economic Journal, Vol. 119, Issue 538: 374-403.

Oberfield, Ezra, and Devesh Raval. 2014. "Micro Data and Macro Technology.” NBER Working Paper, September, No. 20452.

Organisation for Economic Cooperation and Development (OECD). 2013. "Protecting Jobs, Enhancing Flexibility: A New Look at Employment Protection Legislation.” Chapter 2, OECD Employment Outlook 2013, Paris.

Organisation for Economic Cooperation and Development (OECD). 2012. "Understanding the Downward Trend in Labor Income Shares." Chapter 3, OECD Employment Outlook 2012, Paris.

Rajan, Raghuram G. and Luigi Zingales. 1998. "Financial Dependence and Growth." American Economic Review, Vol. 88, No. 3, June: 559-586.

Rios-Rull, Jose-Victor and Raul Santaeulalia-Llopis. 2010. "Redistributive shocks and productivity shocks.” Journal of Monetary Economics. Vol. 57: 931-948.

Romer, Christina D., and David Romer. 2017 "New Evidence on the Impact of Financial Crises in Advanced Countries." American Economic Review. Vol. 107, No. 110, October 2017: 3072-3118

Romer, Christina D., and David Romer. 2010. "The Macroeconomic Effects of Tax Changes: Estimates Based on a New Measure of Fiscal Shocks." American Economic Review, Vol. 100, No.3, June: 763-801.

Romer, Christina D., and David Romer. 2004. “A New Measure of Monetary Shocks: Derivation and Implications." American Economic Review. Vol. 94, No. 4, September: 1055-1084

Romer, Christina D., and David Romer. 1989. "Does Monetary Policy Matter? A New Test in the Spirit of Friedman and Schwartz." NBER Macroeconomics Annual, 4: 121-170.

Rognlie, Matthew. 2015. "Decipering the Fall and Rise in the Net Capital Share:

Accumulation or Scarcity.” Brookings Papers on Economic Activity, Spring: 1-69.

Teulings, Coen N., Nikolay Zubanov. 2014. "Is Economic Recovery a Myth? Robust

Estimates of Impulse Responses." Journal of Applied Econometrics, Vol. 29: 497-514 
Tommasi, Mariano, and Andres Velasco. 1996. "Where Are We in the Political Economy of Reform?” Journal of Economic Policy Reform, Vol. 1, Issue 2: 187-238

Visser, Jelle. 2016. “ICTWSS Data base. Version 5.1.” Database. Amsterdam: Amsterdam Institute for Advanced Labour Studies (AIAS), University of Amsterdam. 


\title{
Figures
}

\section{Figure 1. Cumulative Changes in Country Labor Shares Around Reform Years}

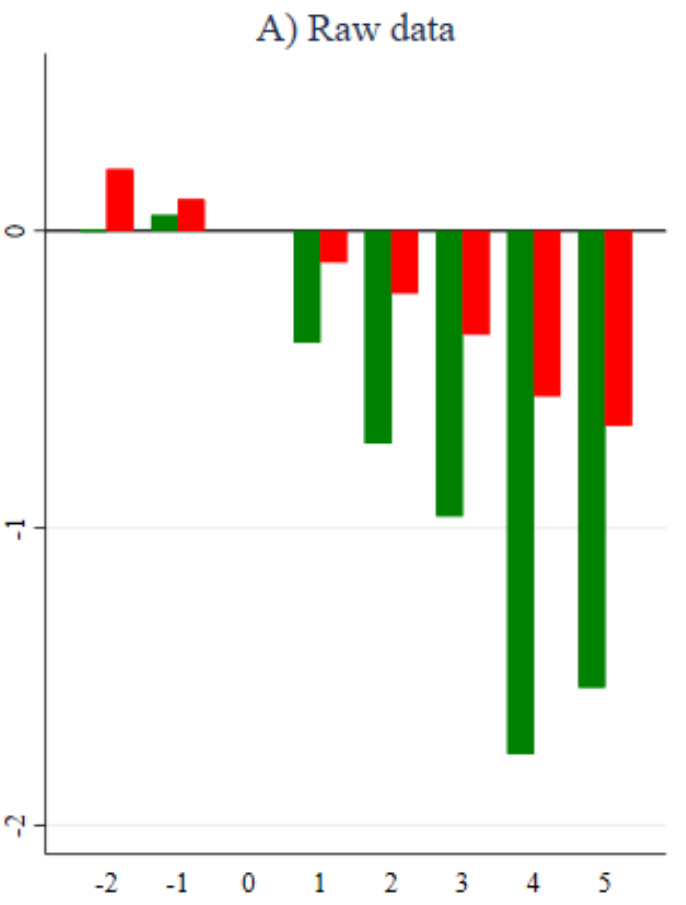

\author{
B): Deviations from trend
}

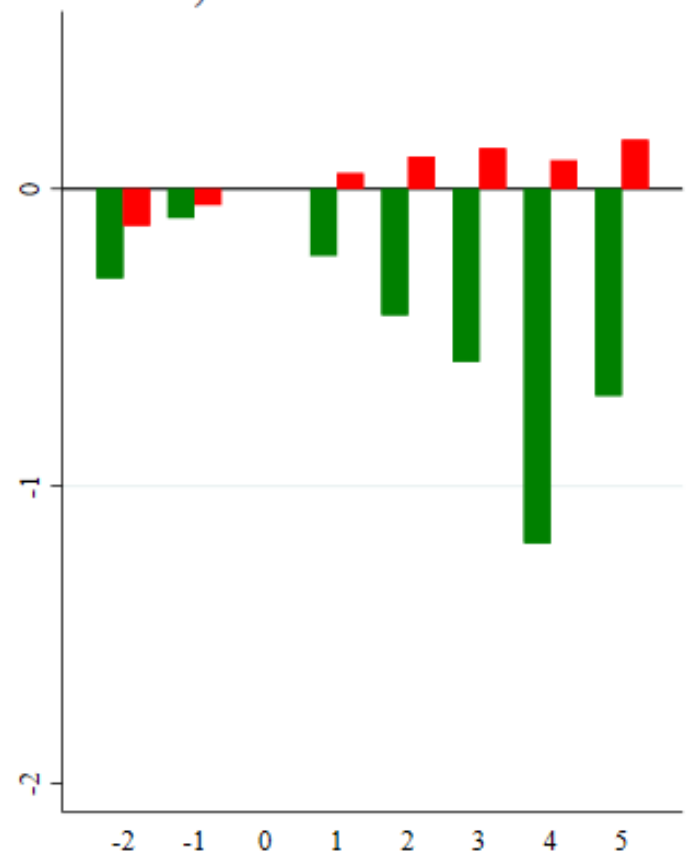

Reforming countries

Status quo countries

Notes: The Figure compares the mean cumulative change in country labor shares relative to reform years in (i) reforming countries (green bars), and (ii) status quo countries (red bars). Panel A reports changes in the raw data, Panel B reports changes in de-meaned and de-trended data. The y-axis measures the size of the mean cumulative change (in percentage points). The $\mathrm{x}$-axis represents the number of years before (negative numbers) and after (positive numbers) the base year (denoted by 0 ). 
Figure 2. Cumulative Changes in Industry Labor Shares Around Reform Years by Industry
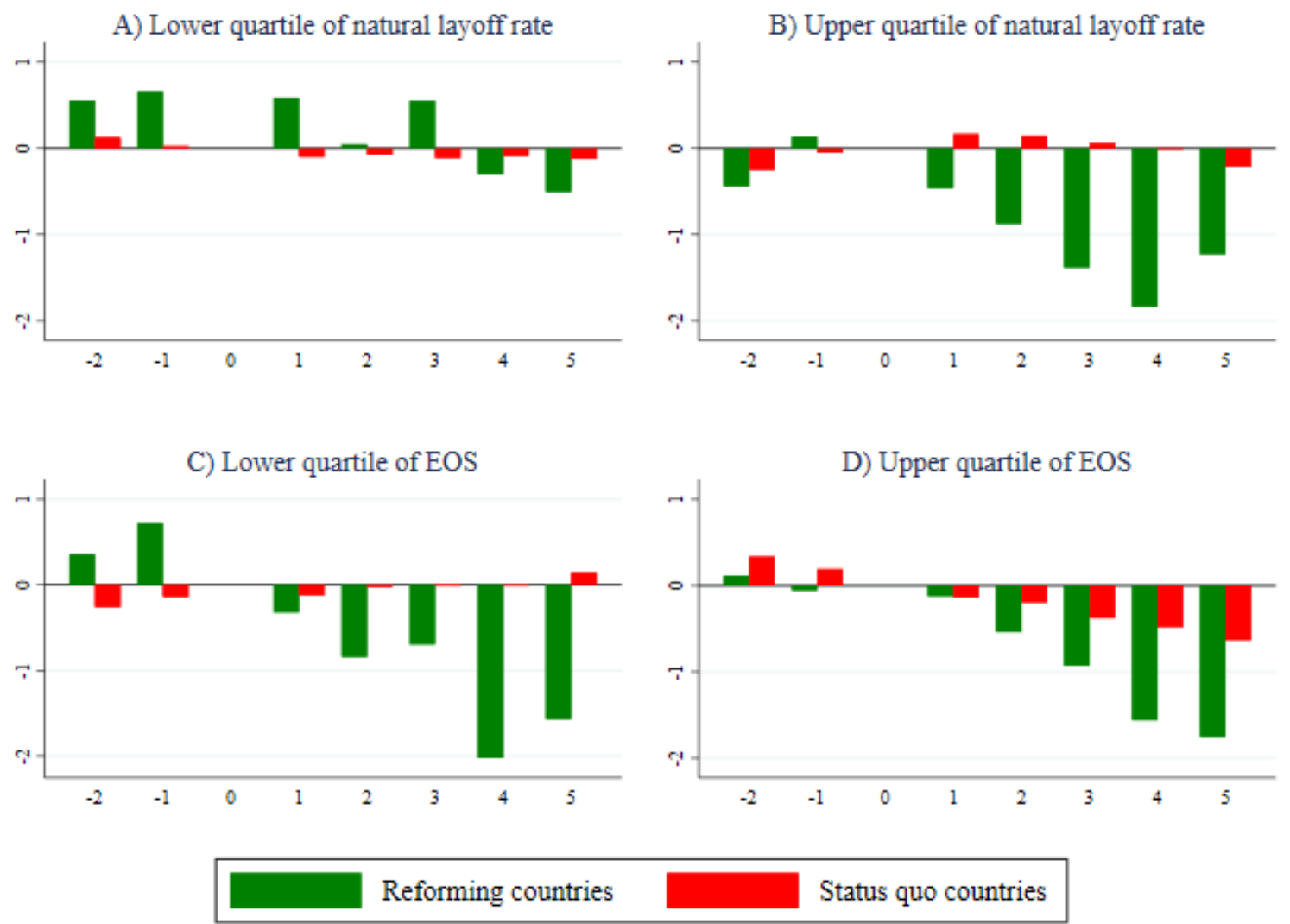

Notes: The Figure compares the mean cumulative change in country-industry labor shares relative to years of EPL reforms in (i) reforming countries (green bars), and (ii) status quo countries (red bars), and for industries in the lower (Panel A) and upper (Panel B) quartiles of the layoff rates as well as those in the lower (Panel C) and upper (Panel D) quartiles of the elasticities of substitution. The $y$-axis measures the size of the labor share change (in percentage points). The $\mathrm{x}$-axis represents the number of years before (negative numbers) and after (positive numbers) the base year (denoted by 0 ). 
Figure 3. Country-level Analysis-Baseline Results

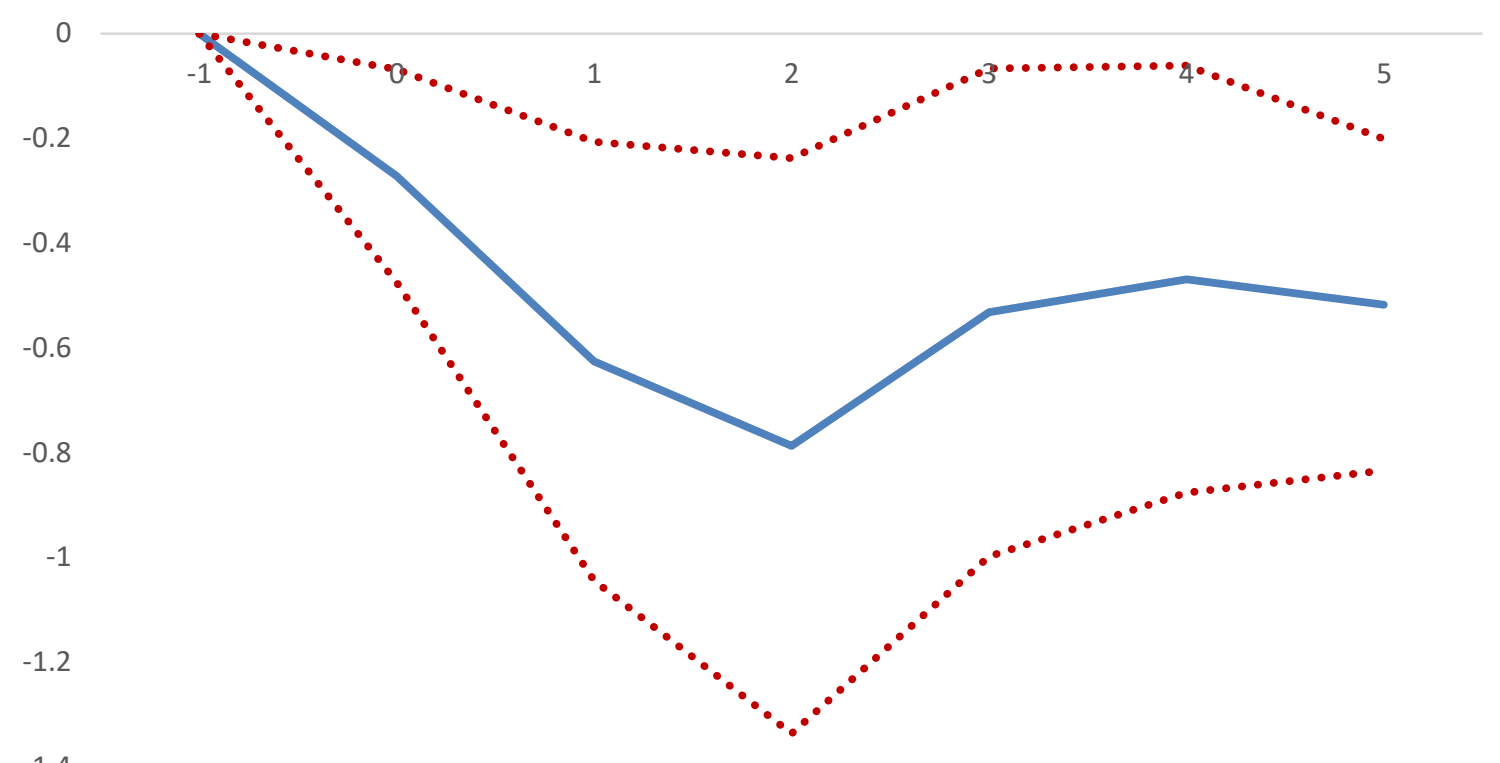

$-1.4$

Notes: estimates based on Equation (8). Solid line denotes the percentage point response of labor share to EPL reforms. Dotted lines indicate 90 percent confidence interval based on clustered standard errors. The X-axis reports the horizon, with 0 indicating the reform year. The $\mathrm{Y}$-axis reports the magnitude of the estimated coefficients (in percentage points). 


\section{Figure 4. Country-industry-level analysis-Baseline Results}

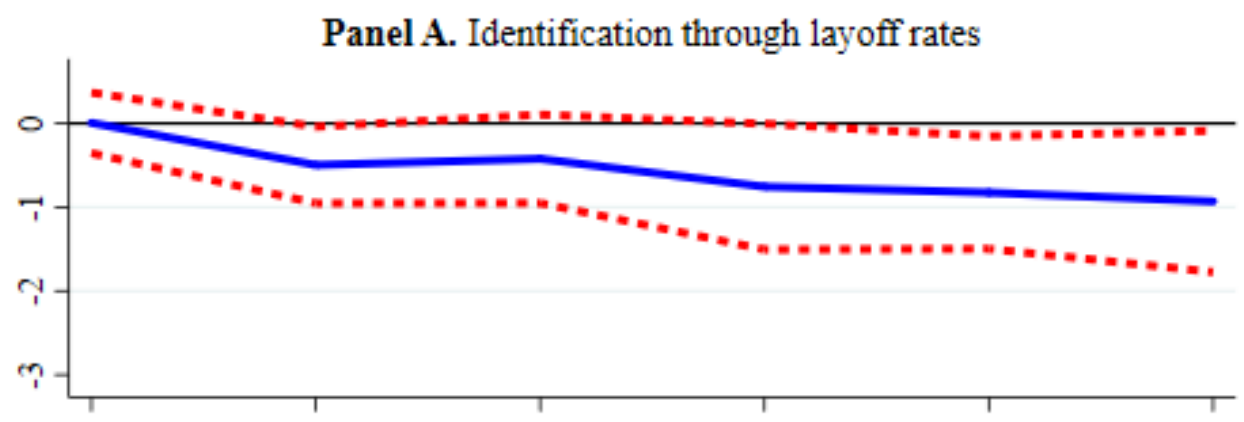

Panel B. Identification through elasticities of substitution

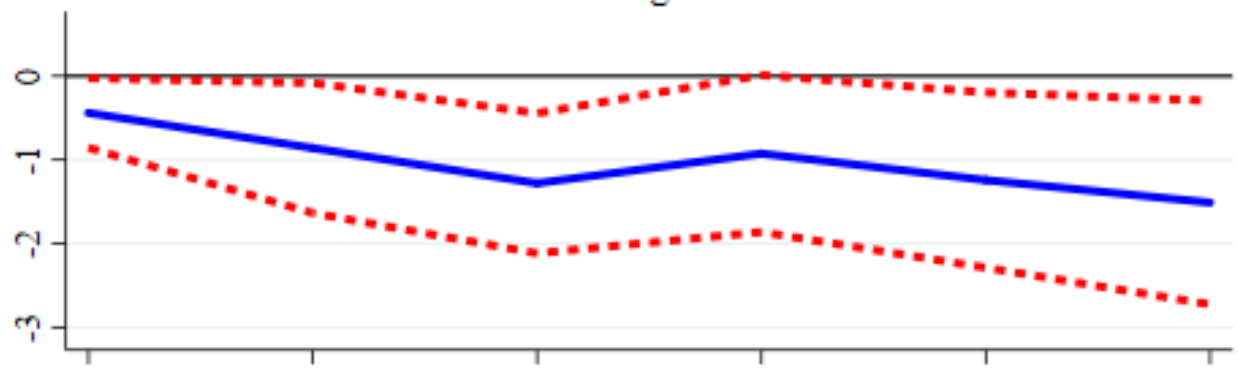

Panel C. Identification through layoff rates and elasticities of substitution

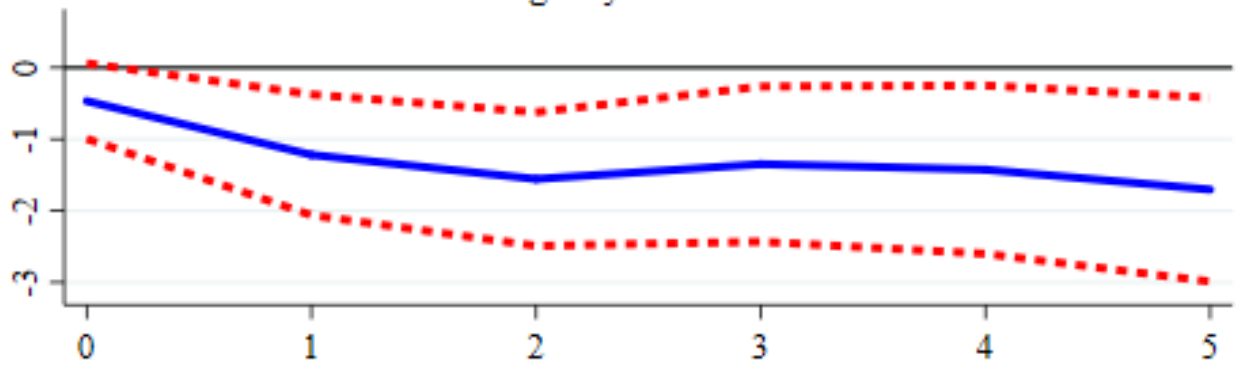

Notes: estimates based on Equation (9). Solid lines denote the estimated average differential labor share effect of EPL reforms between industries in the $75^{\text {th }}$ percentile and $25^{\text {th }}$ percentile of the layoff rates distribution (Panel A), in the $25^{\text {th }}$ percentile and $75^{\text {th }}$ percentile of the distribution of the elasticities of substitution (Panel B) and in the $25^{\text {th }}$ percentile and $75^{\text {th }}$ percentile of the distribution of the interaction between the two (Panel C). Dotted lines indicate 90 percent confidence interval based on standard errors clustered at the country-industry level. For Panels B and C standard errors are obtained through bootstrapping (500 replications. The Y-axis reports the magnitude of the estimated coefficients (in percentage points), while the $\mathrm{X}$-axis reports the response horizon (in years). 
Figure 5. Country-industry-level Analysis: Robustness to Excluding Individual Countries from the Sample

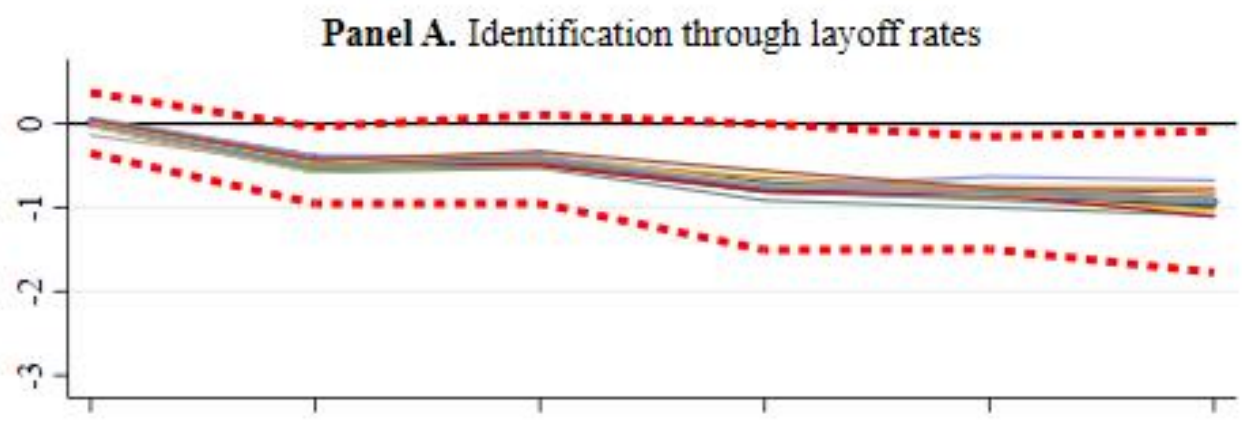

Panel B. Identification through elasticities of substitution

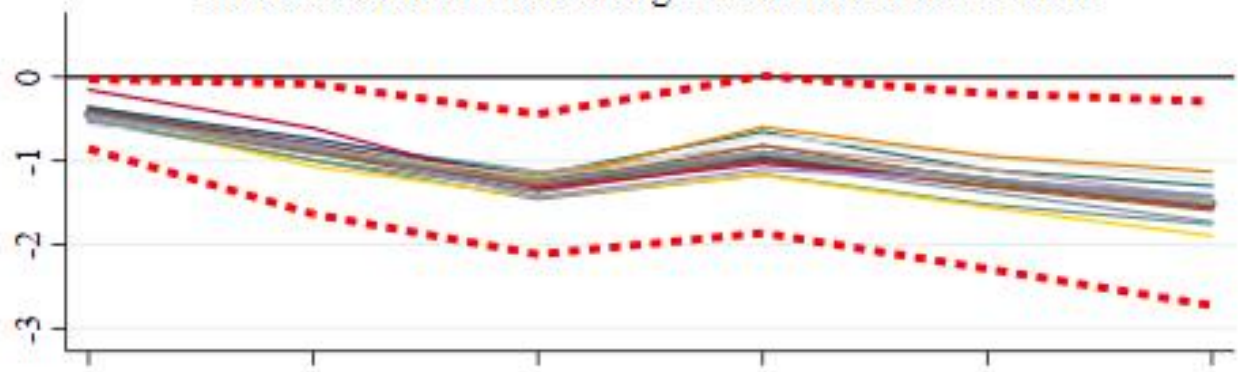

Panel C. Identification through layoff rates and elasticities of substitution

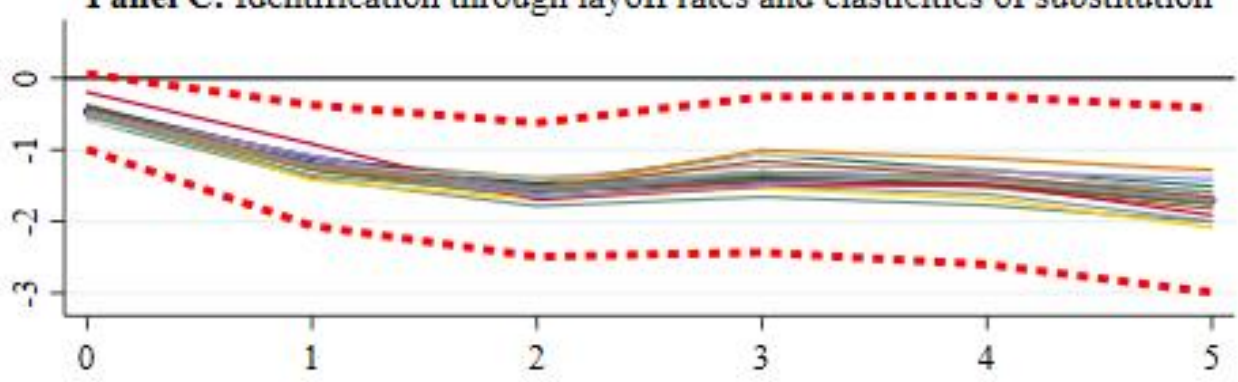

Notes: estimates based on Equation (9). Each solid line represents estimates obtained excluding one country at a time. Red dotted lines indicate the 90 percent confidence interval based on standard errors clustered at the country-industry level obtained from the baseline specification, including all countries. For Panels B and C standard errors are obtained through bootstrapping (500 replications). The Y-axis reports the magnitude of the estimated coefficients (in percentage points), while the X-axis reports the response horizon (in years). For a definition of Panels A, B, C, see notes to Figure 4. 


\section{Figure 6. Country-industry-level analysis: Robustness to Excluding Individual Industries from the Eample}

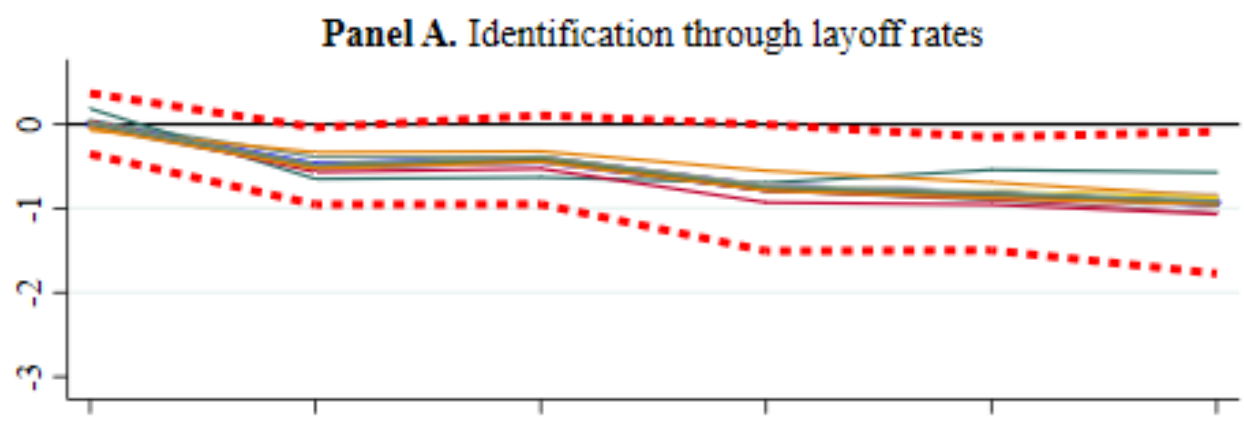

Panel B. Identification through elasticities of substitution
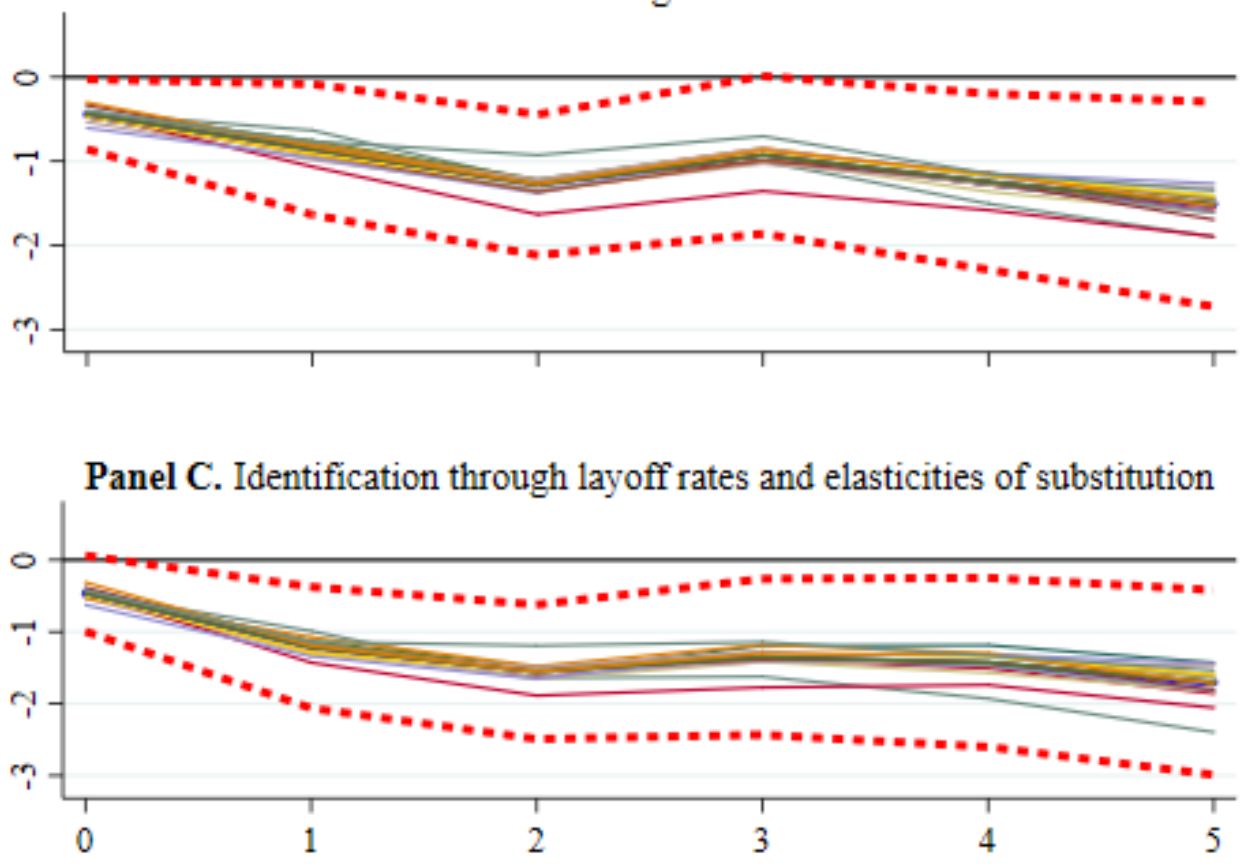

Notes: estimates based on Equation (9). Each solid line represents estimates obtained excluding one industry at a time. Red dotted lines indicate the 90 percent confidence interval based on standard errors clustered at the country-industry level obtained from the baseline specification, including all countries. For Panels B and C standard errors are obtained through bootstrapping (500 replications). The Y-axis reports the magnitude of the estimated coefficients (in percentage points), while the $\mathrm{X}$-axis reports the response horizon (in years). For a definition of Panels A, B, C, see notes to Figure 4. 
Tables

Table 1. Country-level Analysis: Robustness Checks

\begin{tabular}{lcccccc}
\hline & Impact & $\mathbf{1 y}$ & $\mathbf{2 y}$ & $\mathbf{3 y}$ & $\mathbf{4 y}$ & $\mathbf{5 y}$ \\
\hline & & & & & & \\
Baseline & $\mathbf{- 0 . 2 7}$ & $\mathbf{- 0 . 6 3}$ & $\mathbf{- 0 . 7 8}$ & $\mathbf{- 0 . 5 3}$ & $\mathbf{- 0 . 4 7}$ & $\mathbf{- 0 . 5 5}$ \\
Other labor share drivers & $\mathbf{- 0 . 2 6}$ & $\mathbf{- 0 . 5 8}$ & $\mathbf{- 0 . 8 5}$ & $\mathbf{- 0 . 6 9}$ & $\mathbf{- 0 . 6 2}$ & $\mathbf{- 0 . 6 9}$ \\
(Exp.) GDP & $\mathbf{- 0 . 2 8}$ & $\mathbf{- 0 . 6 1}$ & $\mathbf{- 0 . 7 3}$ & $\mathbf{- 0 . 4 7}$ & $\mathbf{- 0 . 4 7}$ & $\mathbf{- 0 . 4 9}$ \\
\hline
\end{tabular}

Notes: estimates based on Equation (8). Coefficients are in percentage points. Bold numbers indicate significance at the 90 percent confidence interval, based on clustered standard errors. The row "Other labor share drivers" reports estimates from a regression including the change in union density, the relative investment price, the trade openness as controls. The row "(Exp. GDP)" reports estimates based on a regression including current, past and expected future GDP growth as controls.

Table 2. Country-industry-level Analysis: Robustness Checks on Lag Specification

\begin{tabular}{lcccccc}
\hline & Impact & $\mathbf{1 y}$ & $\mathbf{2 y}$ & $\mathbf{3 y}$ & $\mathbf{4 y}$ & $\mathbf{5 y}$ \\
\hline \multicolumn{2}{l}{ Panel A) Identification } & through layoff rates & & & & \\
Baseline (2 lags) & 0.01 & $\mathbf{- 0 . 5 0}$ & -0.42 & -0.76 & $\mathbf{- 0 . 8 3}$ & $\mathbf{- 0 . 9 3}$ \\
1 lag & 0.01 & $\mathbf{- 0 . 5 0}$ & $\mathbf{- 0 . 6 3}$ & $\mathbf{- 0 . 7 5}$ & $\mathbf{- 0 . 7 9}$ & $\mathbf{- 0 . 9 4}$ \\
3 lags & 0.01 & -0.35 & -0.48 & $\mathbf{- 0 . 8 5}$ & $\mathbf{- 0 . 8 7}$ & $\mathbf{- 0 . 9 8}$ \\
4 lags & 0.03 & -0.40 & -0.54 & $\mathbf{- 1 . 0 0}$ & $\mathbf{- 1 . 1 0}$ & $\mathbf{- 1 . 2 5}$ \\
No forward dummies & 0.01 & $\mathbf{- 0 . 4 8}$ & -0.37 & -0.58 & -0.70 & $\mathbf{- 0 . 7 4}$
\end{tabular}

Panel B) Identification through elasticities of substitution

$\begin{array}{lllllll}\text { Baseline (2 lags) } & \mathbf{- 0 . 4 4} & \mathbf{- 0 . 8 6} & \mathbf{- 1 . 2 8} & -0.93 & \mathbf{- 1 . 2 4} & \mathbf{- 1 . 5 1} \\ \text { 1 lag } & -0.39 & \mathbf{- 0 . 8 1} & \mathbf{- 1 . 4 5} & -0.85 & \mathbf{- 1 . 1 3} & \mathbf{- 1 . 4 3} \\ \text { 3 lags } & \mathbf{- 0 . 4 8} & \mathbf{- 0 . 7 4} & \mathbf{- 1 . 3 9} & \mathbf{- 1 . 0 8} & \mathbf{- 1 . 3 5} & \mathbf{- 1 . 6 3} \\ \text { 4 lags } & \mathbf{- 0 . 5 3} & \mathbf{- 0 . 9 0} & \mathbf{- 1 . 5 2} & \mathbf{- 1 . 3 5} & \mathbf{- 1 . 7 2} & \mathbf{- 2 . 0 8} \\ \text { No forward dummies } & \mathbf{- 0 . 4 4} & \mathbf{- 0 . 7 9} & \mathbf{- 0 . 8 6} & -0.60 & -1.28 & \mathbf{- 1 . 1 2}\end{array}$

Panel C) Identification through layoff rates and elasticities of substitution

$\begin{array}{lllllll}\text { Baseline (2 lags) } & -0.47 & \mathbf{- 1 . 2 2} & \mathbf{- 1 . 5 6} & \mathbf{- 1 . 3 5} & \mathbf{- 1 . 4 2} & \mathbf{- 1 . 7 0} \\ \text { 1 lag } & -0.45 & \mathbf{- 1 . 2 1} & \mathbf{- 1 . 9 4} & \mathbf{- 1 . 3 2} & \mathbf{- 1 . 3 7} & \mathbf{- 1 . 7 2} \\ \text { 3 lags } & -0.50 & \mathbf{- 0 . 9 7} & \mathbf{- 1 . 6 8} & \mathbf{- 1 . 5 2} & \mathbf{- 1 . 5 4} & \mathbf{- 1 . 8 3} \\ \text { 4 lags } & -0.51 & \mathbf{- 1 . 1 5} & \mathbf{- 1 . 8 3} & \mathbf{- 1 . 8 8} & \mathbf{- 2 . 0 6} & \mathbf{- 2 . 4 8} \\ \text { No forward dummies } & -0.47 & \mathbf{- 1 . 1 3} & \mathbf{- 1 . 1 2} & -0.95 & -1.44 & \mathbf{- 1 . 3 0}\end{array}$

Notes: estimates based on Equation (9). The row "Baseline" reports estimates obtained from the baseline specification, which includes two lags of both the EPL reform dummy and the first difference of the industrycountry labor share at time $t$. The rows "1 lag", "3 lags" and "4 lags" report estimates obtained including, respectively, 1, 3 and 4 lags of the aforementioned variables. The row "No forward dummies" report estimates from a specification that does not include the corrections - namely including forward shocks - advocated by Teulings and Zubanov (2014). Coefficients are in percentage points. Bold numbers indicate significance at the 90 percent confidence interval, based on standard errors clustered at the country-industry level. For Panels B and C standard errors are obtained through bootstrapping (500 replications). For a definition of Panels A, B, C, see notes to Figure 4. 
Table 3. Country-industry-level Analysis: Robustness Checks on Sample Composition

\begin{tabular}{lcccccc}
\hline & Impact & $\mathbf{1 y}$ & $\mathbf{2 y}$ & $\mathbf{3 y}$ & $\mathbf{4 y}$ & $\mathbf{5 y}$ \\
\hline Panel A) Identification through layoff rates & & & & \\
Baseline & 0.01 & $\mathbf{- 0 . 5 0}$ & -0.42 & -0.76 & $\mathbf{- 0 . 8 3}$ & $\mathbf{- 0 . 9 3}$ \\
All manufacturing & -0.06 & $\mathbf{- 0 . 3 3}$ & -0.22 & -0.31 & -0.30 & $\mathbf{- 0 . 4 9}$ \\
Control group & $\mathbf{- 0 . 2 5}$ & $\mathbf{- 0 . 5 6}$ & $\mathbf{- 0 . 5 4}$ & $\mathbf{- 1 . 0 4}$ & $\mathbf{- 0 . 9 7}$ & $\mathbf{- 0 . 6 2}$ \\
KLEMS 2017 database & 0.06 & -0.44 & -0.48 & $\mathbf{- 0 . 9 4}$ & $\mathbf{- 0 . 8 9}$ & $\mathbf{- 0 . 9 6}$
\end{tabular}

Panel B) Identification through elasticities of substitution

$\begin{array}{lllllll}\text { Baseline } & \mathbf{- 0 . 4 4} & \mathbf{- 0 . 8 6} & \mathbf{- 1 . 2 8} & -0.93 & \mathbf{- 1 . 2 4} & \mathbf{- 1 . 5 1} \\ \text { All manufacturing } & -0.46 & \mathbf{- 0 . 8 9} & \mathbf{- 1 . 2 5} & -0.86 & \mathbf{- 1 . 1 5} & \mathbf{- 1 . 5 0} \\ \text { Control group } & \mathbf{- 0 . 7 3} & \mathbf{- 1 . 1 5} & \mathbf{- 1 . 5 3} & \mathbf{- 1 . 6 4} & \mathbf{- 1 . 7 4} & \mathbf{- 1 . 5 2} \\ \text { KLEMS 2017 database } & -0.35 & -0.66 & \mathbf{- 1 . 2 0} & \mathbf{- 1 . 0 8} & \mathbf{- 1 . 2 9} & \mathbf{- 1 . 5 1}\end{array}$

Panel C) Identification through layoff rates and elasticities of substitution

\begin{tabular}{lllllll} 
Baseline & -0.47 & $\mathbf{- 1 . 2 2}$ & $\mathbf{- 1 . 5 6}$ & $\mathbf{- 1 . 3 5}$ & $\mathbf{- 1 . 4 2}$ & $\mathbf{- 1 . 7 0}$ \\
All manufacturing & -0.39 & $\mathbf{- 0 . 9 6}$ & $\mathbf{- 1 . 0 5}$ & -0.80 & -0.77 & $\mathbf{- 1 . 2 1}$ \\
Control group & $\mathbf{- 0 . 7 7}$ & $\mathbf{- 1 . 5 0}$ & $\mathbf{- 1 . 7 5}$ & $\mathbf{- 2 . 0 2}$ & $\mathbf{- 1 . 9 5}$ & $\mathbf{- 1 . 6 6}$ \\
KLEMS 2017 database & -0.40 & $\mathbf{- 1 . 0 2}$ & $\mathbf{- 1 . 5 7}$ & $\mathbf{- 1 . 5 9}$ & $\mathbf{- 1 . 5 2}$ & $\mathbf{- 1 . 7 7}$ \\
\hline
\end{tabular}

Notes: estimates based on Equation (9). The row "Baseline" reports estimates obtained from the baseline specification, which includes 22 countries and excludes the (i) Coke, Refined Petroleum and Nuclear Fuel, (ii) Other Manufacturing, (iii) Public Administration, Defense and Social Security, (iv) Education, (v) Health and Social Work, (vi) Agriculture, and (vii) Construction industries. The row "All manufacturing" reports estimates obtained also including industries (i) and (ii). The row "Control group" reports estimates obtained using industries (iii)-to-(vii) as control group. The row "KLEMS 2017 database" report estimates obtained using only the 18 countries covered by the 2017 EU KLEMS database. Coefficients are in percentage points. Bold numbers indicate significance at the 90 percent confidence interval, based on clustered standard errors at the countryindustry level. For Panels B and C standard errors are obtained through bootstrapping (500 replications). For a definition of Panels A, B, C, see notes to Figure 4. 
Table 4. Country-industry Analysis: Robustness Checks on the Layoff Rates

\begin{tabular}{|c|c|c|c|c|c|c|}
\hline & Impact & $1 \mathbf{y}$ & $2 y$ & $3 y$ & $4 y$ & $5 y$ \\
\hline \multicolumn{7}{|c|}{ Panel A) Identification through layoff rates } \\
\hline Baseline & 0.01 & -0.50 & -0.42 & -0.76 & -0.83 & -0.93 \\
\hline Qualitative measure & 0.01 & -0.34 & -0.61 & -1.48 & -1.05 & -1.46 \\
\hline 2013 layoff rate & 0.11 & -0.74 & -0.46 & -0.68 & -0.69 & -0.77 \\
\hline \multicolumn{7}{|c|}{ Panel B) Identification through layoff rates and elasticities of substitution } \\
\hline Baseline & -0.47 & -1.22 & -1.56 & -1.35 & -1.42 & -1.70 \\
\hline Qualitative measure & 0.02 & -0.07 & -0.10 & -0.20 & -0.22 & -0.26 \\
\hline 2013 layoff rate & -0.40 & -1.17 & -1.37 & -1.09 & -1.13 & -1.27 \\
\hline
\end{tabular}

Notes: estimates based on Equation (9). The row "Baseline" reports estimates obtained from the baseline specification, relying on the average layoff rate calculated using the 2014 Displaced Workers Survey (covering the 2011-2013 period). The row "Qualitative measure" relies on a binary variable that takes value $1(0)$ in industries whose layoff rate was above (below) the median for all the three years covered by the 2014 Displaced Workers Survey. The row "2013 layoff rate" report estimates obtained using the layoff rate calculated for the year 2013. Coefficients are in percentage points. Bold numbers indicate significance at the 90 percent confidence interval, based on clustered standard errors at the country-industry level. For Panel B standard errors are obtained through bootstrapping (500 replications).

Table 5. Country-industry Analysis: Robustness Checks on the Elasticities of Substitution

\begin{tabular}{|c|c|c|c|c|c|c|}
\hline & Impact & $\mathbf{1 y}$ & $2 y$ & $3 \mathbf{y}$ & $4 y$ & $5 y$ \\
\hline \multicolumn{7}{|c|}{ Panel A) Identification through elasticities of substitution } \\
\hline Baseline & -0.44 & -0.86 & -1.28 & -0.93 & -1.24 & -1.51 \\
\hline Stock & -0.53 & -0.52 & -1.49 & -0.78 & -0.93 & -1.45 \\
\hline Rental rate & -0.30 & -0.83 & -0.82 & -0.70 & -0.99 & -1.28 \\
\hline Technical change & -0.38 & -0.72 & -0.86 & -0.65 & -1.10 & -1.19 \\
\hline \multicolumn{7}{|c|}{ Panel B) Identification through layoff rates and elasticities of substitution } \\
\hline Baseline & -0.47 & -1.22 & -1.56 & -1.35 & -1.42 & -1.70 \\
\hline Stock & -0.50 & -1.05 & -1.92 & -1.43 & -1.41 & -1.86 \\
\hline Rental rate & -0.38 & -1.19 & -1.11 & -1.08 & -1.17 & -1.53 \\
\hline Technical change & -0.41 & -1.09 & -1.17 & -1.10 & -1.26 & -1.40 \\
\hline
\end{tabular}

Notes: estimates based on Equation (9). The row "Baseline" reports estimates obtained from the baseline specification, relying on elasticities of substitution (EOS) estimated using data on capital services and capital rental rates calculated as in Jorgenson (1963), and (iii) assuming Hicks-neutral technical change. The row "Stock" report estimates obtained using real capital stock rather than capital services data. The row "Rental rate" report estimates obtained using data on nominal capital stock divided by capital services to proxy for the rental rate of capital. The row "Technical change" report estimates obtained when relaxing the assumption of Hicks-neutral technical change. Bold numbers indicate significance at the 90 percent confidence interval, based on bootstrapped standard errors (500 replications), clustered at the country-industry level. 
Table 6. Country-industry-level Analysis: Robustness Checks on Potential Omitted Variables

\begin{tabular}{lcccccc}
\hline & \multicolumn{1}{c}{ Impact } & $\mathbf{1 y}$ & $\mathbf{2 y}$ & $\mathbf{3 y}$ & $\mathbf{4 y}$ & $\mathbf{5 y}$ \\
\hline $\begin{array}{l}\text { Panel A) Identification through layoff rates } \\
\text { Baseline }\end{array}$ & 0.01 & $\mathbf{- 0 . 5 0}$ & -0.42 & -0.76 & $\mathbf{- 0 . 8 3}$ & $\mathbf{- 0 . 9 3}$ \\
Relative investment price & 0.03 & -0.42 & -0.48 & $\mathbf{- 0 . 7 9}$ & $\mathbf{- 0 . 8 4}$ & $\mathbf{- 1 . 1 0}$ \\
Trade openness & 0.01 & -0.45 & -0.50 & $\mathbf{- 0 . 8 3}$ & $\mathbf{- 0 . 8 8}$ & $\mathbf{- 1 . 1 3}$ \\
Trade union density & 0.02 & -0.43 & -0.48 & $\mathbf{- 0 . 8 1}$ & $\mathbf{- 0 . 7 8}$ & $\mathbf{- 1 . 0 0}$ \\
& & & & & \\
Panel B) Identification through elasticities of substitution & & & \\
Baseline & $\mathbf{- 0 . 4 4}$ & $\mathbf{- 0 . 8 6}$ & $\mathbf{- 1 . 2 8}$ & -0.93 & $\mathbf{- 1 . 2 4}$ & $\mathbf{- 1 . 5 1}$ \\
Relative investment price & -0.15 & -0.60 & $\mathbf{- 1 . 3 4}$ & $\mathbf{- 1 . 0 4}$ & $\mathbf{- 1 . 2 4}$ & $\mathbf{- 1 . 5 7}$ \\
Trade openness & -0.18 & -0.63 & $\mathbf{- 1 . 3 6}$ & $\mathbf{- 1 . 0 8}$ & $\mathbf{- 1 . 3 1}$ & $\mathbf{- 1 . 6 7}$ \\
Trade union density & -0.16 & -0.60 & $\mathbf{- 1 . 3 9}$ & $\mathbf{- 1 . 1 1}$ & $\mathbf{- 1 . 1 9}$ & $\mathbf{- 1 . 4 7}$
\end{tabular}

Panel C) Identification through layoff rates and elasticities of substitution

$\begin{array}{lllllll}\text { Baseline } & -0.47 & \mathbf{- 1 . 2 2} & \mathbf{- 1 . 5 6} & \mathbf{- 1 . 3 5} & \mathbf{- 1 . 4 2} & \mathbf{- 1 . 7 0} \\ \text { Relative investment price } & -0.19 & \mathbf{- 0 . 9 0} & \mathbf{- 1 . 7 0} & \mathbf{- 1 . 5 1} & \mathbf{- 1 . 4 8} & \mathbf{- 1 . 9 3} \\ \text { Trade openness } & -0.23 & \mathbf{- 0 . 9 4} & \mathbf{- 1 . 7 2} & \mathbf{- 1 . 5 6} & \mathbf{- 1 . 5 6} & \mathbf{- 2 . 0 2} \\ \text { Trade union density } & -0.20 & \mathbf{- 0 . 9 1} & \mathbf{- 1 . 7 3} & \mathbf{- 1 . 5 9} & \mathbf{- 1 . 4 1} & \mathbf{- 1 . 7 5}\end{array}$

Notes: estimates based on Equation (9). The row "Baseline" reports estimates obtained from the baseline specification, only including reform to temporary contracts as control variable. The rows "Relative investment price", "Trade openness" "Trade union density" report estimates obtained including as additional control variables, respectively, the relative price of investment goods, the sum of import and exports as a share of GDP and the change in trade union density - all of which interacted with the relevant industry characteristic. Bold numbers indicate significance at the 90 percent confidence interval, based on clustered standard errors at the country-industry level. For Panels B and C standard errors are obtained through bootstrapping (500 replications). For a definition of Panels A, B, C, see notes to Figure 4.

Table 7. Country-industry-level Analysis: Extension on Labor Share Drivers

\begin{tabular}{lcccccc}
\hline & Impact & $\mathbf{1 y}$ & $\mathbf{2 y}$ & $\mathbf{3 y}$ & $\mathbf{4 y}$ & $\mathbf{5 y}$ \\
\hline Identification through layoff rates & & & & & \\
Labor share & 0.01 & $\mathbf{- 0 . 5 0}$ & -0.42 & -0.76 & $\mathbf{- 0 . 8 3}$ & $\mathbf{- 0 . 9 3}$ \\
Real wage & 0.22 & $\mathbf{- 0 . 9 6}$ & $\mathbf{- 1 . 2 2}$ & $\mathbf{- 1 . 3 8}$ & $\mathbf{- 1 . 4 7}$ & $\mathbf{- 1 . 3 0}$ \\
Employment & 0.11 & $\mathbf{0 . 4 1}$ & 0.42 & $\mathbf{0 . 8 3}$ & 0.66 & 0.19 \\
Capital-to-output ratio & 1.45 & 2.84 & 0.49 & -2.30 & -4.66 & -3.87 \\
\hline
\end{tabular}

Notes: estimates based on Equation (9) and using layoff rates for the identification. The rows "Labor share", "Real wage", "Employment" and "Capital-to-output ratio" report estimates obtained using, respectively, the labor share, the log hourly wage deflated by the price index, the log of engaged individuals and the ratio of the nominal capital stock to value added as dependent variables. Bold numbers indicate significance at the 90 percent confidence interval, based on clustered standard errors at the country-industry level. 
Table 8. Country-industry-level Analysis: Extension on Sample Split According to Elasticity of Substitution

\begin{tabular}{|c|c|c|c|c|c|c|}
\hline & Impact & $\mathbf{1 y}$ & $2 y$ & $3 y$ & $4 y$ & $5 y$ \\
\hline \multicolumn{7}{|c|}{ Identification through layoff rates } \\
\hline Full sample & 0.01 & -0.56 & -0.48 & -0.85 & -0.93 & -1.05 \\
\hline Elasticity above 1 & 0.96 & 1.30 & 1.51 & 1.83 & 1.39 & 0.86 \\
\hline Elasticity below 1 & 0.01 & -0.61 & -0.47 & -0.92 & -0.92 & -0.98 \\
\hline
\end{tabular}




\section{Appendix 1. Dataset of Reforms}

\section{Table A1.1. Reforms events}

\begin{tabular}{|c|c|c|c|c|c|c|c|}
\hline Country & $\begin{array}{c}\text { Impleme } \\
\text { ntation/ } \\
\text { Scored } \\
\text { Year }\end{array}$ & Area & Content & Normative language & $\begin{array}{c}\text { Mention } \\
\text { in other } \\
\text { reports }\end{array}$ & $\begin{array}{l}\text { Large change } \\
\text { in OECD } \\
\text { indicator }\end{array}$ & Score \\
\hline $\begin{array}{c}\text { United } \\
\text { Kingdom }\end{array}$ & 2000 & $\begin{array}{l}\text { severance } \\
\text { pay }\end{array}$ & $\begin{array}{l}\text { Quadrupling maximum compensation for unfair } \\
\text { dismissals from October } 1999 \text { (pg. 116, 2000) }\end{array}$ & & & yes for 2000 & -1 \\
\hline Austria & 2003 & $\begin{array}{l}\text { severance } \\
\text { pay }\end{array}$ & $\begin{array}{l}\text {... the system underwent thorough reform. In the } \\
\text { new system, which became effective in January } \\
2003 \text {, the management of severance pay is } \\
\text { attributed to retirement accounts, which are legally } \\
\text { independent from the employers and funded by } \\
\text { employers via a monthly untaxed payment of some } \\
1.5 \text { per cent of gross wages. Accumulated } \\
\text { entitlements rest in the employee's account until } \\
\text { retirement, unless the work contract has been } \\
\text { terminated by the employer, which makes cash } \\
\text { payments admissible under certain conditions... } \\
\text { (pg. 66, 2003) }\end{array}$ & & & yes for 2003 & 1 \\
\hline Belgium & 1970 & $\begin{array}{l}\text { notice for } \\
\text { individual } \\
\text { dismissal }\end{array}$ & $\begin{array}{l}\text { In November } 1970 \text {, the notice period, which had } \\
\text { been lengthened from } 21 \text { to } 30 \text { days early in } 1969 \text {, } \\
\text { was increased to three months. The possibility of a } \\
\text { further extension to five months was left open and } \\
\text { the five months' period was applied in most cases. } \\
\text { (pg. 27, 1971) }\end{array}$ & & & $\begin{array}{l}\text { no data but } \\
\text { would qualify } \\
\text { if scoring } \\
\text { applied }\end{array}$ & -1 \\
\hline Belgium & 1971 & $\begin{array}{l}\text { notice for } \\
\text { individual } \\
\text { dismissal }\end{array}$ & $\begin{array}{l}\text { In April 1971, the period of prior notice was } \\
\text { reduced to two months (pg. 27, 1971) }\end{array}$ & & & $\begin{array}{c}\text { no data but } \\
\text { would qualify } \\
\text { if scoring } \\
\text { applied }\end{array}$ & 1 \\
\hline Belgium & 1985 & $\begin{array}{c}\text { severance } \\
\text { pay }\end{array}$ & $\begin{array}{l}\text {...various measures to increase labour market } \\
\text { flexibility: authorisation for ailing businesses to } \\
\text { pay severance allowances in monthly instalments, } \\
\text { when obliged to terminate indefinite-term } \\
\text { contracts; incentives for the development of fixed- } \\
\text { term contracts in order to promote youth } \\
\text { employment and temporary work; lengthening of } \\
\text { probation periods from } 3 \text { and } 6 \text { months to } 6 \text { and } 12 \\
\text { months (pg. } 47,1985 \text { ) }\end{array}$ & $\begin{array}{l}\text { A major effort has also } \\
\text { been made to promote part } \\
\text { time work, temporary } \\
\text { work and fixed-term } \\
\text { contracts... (pg. } 31,1986 \text { ) } \\
\text { A major effort has also } \\
\text { been made to increase } \\
\text { labour flexibility... (pg. } \\
\text { 32, 1986) }\end{array}$ & & no & 1 \\
\hline France & 1987 & $\begin{array}{c}\text { procedural } \\
\text { inconvenie } \\
\text { nce }\end{array}$ & $\begin{array}{l}\text { Checks on the genuineness of redundancies in } \\
\text { firms with fewer than } 10 \text { employees to be } \\
\text { discontinued (and from 1st January 1987, official } \\
\text { authorisation for layoffs no longer necessary). (pg. } \\
\text { 76, 1987) }\end{array}$ & $\begin{array}{c}\text {...one area - employment - } \\
\text { where a deliberately active } \\
\text { economic policy is being } \\
\text { pursued, with } 1985 \\
\text { marking a major shift in } \\
\text { the choice of } \\
\text { instruments... the most } \\
\text { important measure, at least } \\
\text { from a psychological point } \\
\text { of view, was the } \\
\text { discontinuation of the } \\
\text { requirement for official } \\
\text { authorisation to lay off } \\
\text { workers (with full effect } \\
\text { from January 1987)... (pg. } \\
\text { 37, 1987) }\end{array}$ & $\begin{array}{c}\text { pg. } 33 \text { or } \\
44,1989 \text {; } \\
\text { pg. } 59 \text {, } \\
1990\end{array}$ & yes for 1987 & 1 \\
\hline France & 2003 & $\begin{array}{l}\text { collective } \\
\text { dismissal }\end{array}$ & $\begin{array}{l}\text {...government introduced the Social } \\
\text { Modernisation Law in 2002, significantly } \\
\text { tightening the constraints on dismissal of more } \\
\text { than } 10 \text { employees...in } 2003 \text { the new government } \\
\text { suspended some of these provisions before } \\
\text { introducing another law in } 2004 \text { which, while } \\
\text { moderating some aspects of EPL, increased the } \\
\text { obligation on employers to try to find alternative } \\
\text { jobs for employees under threat of collective } \\
\text { dismissal... The law permits "economic" dismissal } \\
\text { only if it is necessary to preserve the } \\
\text { competitiveness of the firm. Financial } \\
\text { rationalisation by the management is not sufficient } \\
\text { justification...in } 2002 \text { the Social Modernisation } \\
\text { Law added a provision requiring that the financial } \\
\text { position of the group to which the firm belongs } \\
\text { should be taken into account, which means that an } \\
\text { economic dismissal is not legally justified if the } \\
\text { group is healthy. (pg. 105, 2005) }\end{array}$ & $\begin{array}{l}\text {...the Social } \\
\text { Modernisation Law in } \\
\text { 2002, significantly } \\
\text { tightening the constraints } \\
\text { on dismissal of more than } \\
10 \text { employees... These } \\
\text { provisions prevent firms } \\
\text { from undertaking } \\
\text { practically any } \\
\text { reorganisation to increase } \\
\text { productivity that might } \\
\text { ensure the survival or } \\
\text { faster growth of the firm } \\
\text { in the future... (pg. 105- } \\
106,2005 \text { ). }\end{array}$ & & yes for 2003 & -1 \\
\hline
\end{tabular}




\begin{tabular}{|c|c|c|c|c|c|c|c|}
\hline France & 2009 & $\begin{array}{l}\text { procedural } \\
\text { inconvenie } \\
\text { nce }\end{array}$ & $\begin{array}{l}\text { Layoff law has been simplified by introducing the } \\
\text { possibility of mutually agreed termination (rupture } \\
\text { conventionnelle) of the CDI. (pg. 52, 2009) }\end{array}$ & & & yes for 2009 & 1 \\
\hline Germany & 1994 & $\begin{array}{l}\text { notice for } \\
\text { individual } \\
\text { dismissal }\end{array}$ & $\begin{array}{l}\text { Notice period for blue-collar workers extended to } \\
\text { four weeks, thereby aligning it with that of white- } \\
\text { collar workers [see e.g. OECD Employment } \\
\text { Outlook 2004 pg. 119] }\end{array}$ & & & yes for 1994 & -1 \\
\hline Germany & 1997 & $\begin{array}{c}\text { procedural } \\
\text { inconvenie } \\
\text { nce }\end{array}$ & $\begin{array}{l}\text { Legislation easing employment protection } \\
\text { provisions...came into force in October } 1996 \ldots \\
\text { The employment ceiling for enterprises above } \\
\text { which employment protection is applicable was } \\
\text { raised from five to ten employees per firm. The } \\
\text { number of enterprises which are not subject to the } \\
\text { general job protection law was thereby increased } \\
\text { by some } 15 \text { percent. These companies employ } \\
\text { some } 30 \text { per cent of all employees... With respect } \\
\text { to large scale redundancies, the general } \\
\text { requirement to consider social criteria in selecting } \\
\text { employees to be made redundant was relaxed, with } \\
\text { greater emphasis given to economic factors... (pg. } \\
\text { 132, 1997) }\end{array}$ & $\begin{array}{l}\ldots \text { the measures reduce } \\
\text { the costs and uncertainty } \\
\text { of taking on new workers, } \\
\text { thereby increasing the } \\
\text { possibility for the } \\
\text { unemployed and new } \\
\text { entrants into the labour } \\
\text { market to make the } \\
\text { transition into permanent } \\
\text { employment... (pg. 132, } \\
\text { 1997) }\end{array}$ & & no & 1 \\
\hline Germany & 2004 & $\begin{array}{l}\text { procedural } \\
\text { inconvenie } \\
\text { nce }\end{array}$ & $\begin{array}{l}\text { The Protection against Dismissal Act (PaDA) } \\
\text { states that a dismissal is "socially unjust" and, } \\
\text { hence, invalid if there is no suitable reason }(\S 1) \text {. } \\
\text { A dismissal is socially justified only (1) in cases of } \\
\text { personal misconduct, (2) lack of individual } \\
\text { capabilities or (3) due to business needs and } \\
\text { compelling operational reasons. Moreover, in the } \\
\text { third case the PaDA requires that firms select } \\
\text { workers or employees to be dismissed in } \\
\text { accordance with social criteria such as age, tenure, } \\
\text { alimony duties or individual disabilities. Until } \\
\text { 2003, the regulations of the PaDA generally } \\
\text { applied to all firms with more than a minimum } \\
\text { number of five permanent employees. Since } 2004 \text {, } \\
\text { the four criteria of age, tenure, maintenance } \\
\text { payments, and individual disability are listed } \\
\text { explicitly in } \S 1(3) \text { of the PaDA [see } \\
\text { http://www.zew.de/en/publikationen/dfgflex/paper } \\
\text { Goerke.pdf] }\end{array}$ & & & yes for 2004 & -1 \\
\hline Italy & 1970 & $\begin{array}{l}\text { procedural } \\
\text { inconvenie } \\
\text { nce }\end{array}$ & $\begin{array}{c}\text { The Act of } 1970 \text { referred to as the "workers' } \\
\text { statute". Mechanism for reinstatement after a } \\
\text { dismissal has been declared unlawful...laid down } \\
\text { by Article } 18 \text { [see } \\
\text { https://www.eurofound.europa.eu/efemiredictionar } \\
\text { y/workers-statute] }\end{array}$ & & & $\begin{array}{l}\text { No data but } \\
\text { would qualify } \\
\text { if scoring } \\
\text { applied }\end{array}$ & -1 \\
\hline Italy & 1991 & $\begin{array}{l}\text { procedural } \\
\text { inconvenie } \\
\text { nce }\end{array}$ & $\begin{array}{l}\text {...the job allocation scheme was abolished in June } \\
1991 \text { (pg. 54, 1991) }\end{array}$ & $\begin{array}{l}\text { A number of important } \\
\text { measures...been taken in } \\
\text { recent years to enhance } \\
\text { the flexibility of the labour } \\
\text { market, most prominent } \\
\text { among them the abolition } \\
\text { of the job allocation } \\
\text { scheme in July 1991 (pg. } \\
19,1994)\end{array}$ & $\begin{array}{l}\text { pg. } 19, \\
1994 \\
\text { pg. } 11 \\
1995 \\
\text { pg. } 134, \\
1999\end{array}$ & no & 1 \\
\hline Italy & 2013 & $\begin{array}{l}\text { procedural } \\
\text { inconvenie } \\
\text { nce }\end{array}$ & $\begin{array}{l}\text { Comprehensive labour market reform (with } \\
\text { explicit provision for monitoring of its effects) } \\
\text { including: relaxation of employment protection } \\
\text { rules, reduced incentives to hire on non-permanent } \\
\text { contacts.... potentially increase in flexibility on } \\
\text { the firing side... (pg. 42, 2013) ... reform relaxed } \\
\text { employment protection rules on permanent } \\
\text { contracts, notably limiting the possibility of } \\
\text { reinstatement following unfair dismissal. (pg. } 27 \text {, } \\
\text { 2015) }\end{array}$ & & $\begin{array}{l}\text { pg. } 27 \\
2015\end{array}$ & yes for 2013 & 1 \\
\hline $\begin{array}{l}\text { Nether- } \\
\text { lands }\end{array}$ & 1976 & $\begin{array}{l}\text { collective } \\
\text { dismissal }\end{array}$ & $\begin{array}{l}\text { Compulsory 3-month advance notification to } \\
\text { employment exchange and trade unions required } \\
\text { for the intended dismissal of } 20 \text { or more } \\
\text { employees (pg. 47, 1977). [Collective Redundancy } \\
\text { Notification Act established rules applying to } \\
\text { collective dismissals] }\end{array}$ & & & $\begin{array}{l}\text { no data but } \\
\text { would qualify } \\
\text { if scoring } \\
\text { applied }\end{array}$ & -1 \\
\hline $\begin{array}{l}\text { Nether- } \\
\text { lands }\end{array}$ & 1996 & $\begin{array}{c}\text { procedural } \\
\text { inconvenie } \\
\text { nce }\end{array}$ & $\begin{array}{l}\text { The Government decides to shorten dismissal } \\
\text { procedures. According to the new rules, an } \\
\text { employer can dismiss his employee at the same }\end{array}$ & & & yes in 1995 & 1 \\
\hline
\end{tabular}

\section{CInternational Monetary Fund. Not for Redistribution}




\begin{tabular}{|c|c|c|c|c|c|c|}
\hline & & & $\begin{array}{l}\text { time or even before asking permission from the } \\
\text { director of the Public Employment Service. (pg. } \\
\qquad 122,1996)\end{array}$ & & & \\
\hline Norway & 1977 & $\begin{array}{l}\text { procedural } \\
\text { inconvenie } \\
\text { nce }\end{array}$ & $\begin{array}{l}\text { The main legislation concerning employment } \\
\text { protection is the law on worker protection and the } \\
\text { working environment which dates back to } 1977 \text {. } \\
\text { The law regulates a number of issues ranging from } \\
\text { the terms of termination of employment, working } \\
\text { hours, overtime and unfair dismissals... (pg. 164, } \\
\text { 2004) }\end{array}$ & $\begin{array}{l}\text { pg. } 164, \\
2004\end{array}$ & no data & -1 \\
\hline Sweden & 1975 & $\begin{array}{l}\text { notice for } \\
\text { individual } \\
\text { dismissal }\end{array}$ & $\begin{array}{l}\text {...introduction of the employment security act in } \\
\text { July } 1974, \text { stipulating that employers are to give } 6 \\
\text { months' warning in advance of layoffs... (pg. } 21 \text {, } \\
\text { 1976) } \\
\text { The Act on Security of Employment, which took } \\
\text { effect in } 1974 \text {, stipulates that an employer must } \\
\text { have acceptable reasons for laying off workers. } \\
\text { Notice of dismissal, which may extend up to six } \\
\text { months depending on age, can be contested in } \\
\text { court and an employee is generally entitled to } \\
\text { retain his employment pending a decision. } \\
\text { Furthermore, employers must give the } \\
\text { Employment Board } 2 \text { to } 6 \text { months notice of } \\
\text { production cutbacks, depending on the number of } \\
\text { employees affected... (pg. } 36-37,1980 \text { ) }\end{array}$ & $\begin{array}{l}\text { pg. } 36- \\
37,1980\end{array}$ & $\begin{array}{l}\text { no data but } \\
\text { would qualify } \\
\text { if scoring } \\
\text { applied }\end{array}$ & -1 \\
\hline Sweden & 1997 & $\begin{array}{l}\text { notice for } \\
\text { individual } \\
\text { dismissal }\end{array}$ & $\begin{array}{l}\text { The revised Employment Protection legislation } \\
\text { enters into force, embodying modifications in i) } \\
\text { the criteria determining the length of notice } \\
\text { periods; ii) enterprises' rehiring obligation vis-'a- } \\
\text { vis laid-off workers; iii) a wider scope for fixed- } \\
\text { term contracts; and ivi a strengthened position for } \\
\text { part-time workers and workers on replacement } \\
\text { contracts. } \\
\text { t. the government tabled a set of proposals which } \\
\text { were adopted by Parliament in late } 1996 \text {, to enter } \\
\text { into force during } 1997 \text {. Of particular importance } \\
\text { are: i) the length of notice periods is to be } \\
\text { determined on the basis of tenure and not of age, } \\
\text { implying that the costs of hiring older workers will } \\
\text { fall relative to other groups; ii) enterprises' } \\
\text { rehiring obligation vis-'a-vis laid-off workers will } \\
\text { expire after nine instead of twelve months; iii) } \\
\text { twelve-month fixed-term contracts with no } \\
\text { restrictions applied to the nature of the work } \\
\text { carried out has been introduced, with all } \\
\text { enterprises regardless of size being allowed to } \\
\text { employ up to five persons on such contracts and } \\
\text { new establishments being allowed to extend them } \\
\text { to eighteen months... (pg. } 81-82,1998 \text { ) }\end{array}$ & $\begin{array}{l}\text { pg. } 105 \text {, } \\
\quad 1999\end{array}$ & $\begin{array}{l}\text { yes in } 1997 \\
\text { and } 1999\end{array}$ & 1 \\
\hline Japan & 2007 & $\begin{array}{l}\text { procedural } \\
\text { inconvenie } \\
\text { nce }\end{array}$ & $\begin{array}{l}\text { Labor Contract Act of } 2007 \text { [see e.g. } \\
\text { http://apirnet.ilo.org/resources/the-labor-contract- } \\
\frac{\text { act-of-2007-and-other-legislative- }}{\text { developments/at download/file1]]. }}\end{array}$ & & yes in 2007 & 1 \\
\hline Finland & 1989 & $\begin{array}{l}\text { notice for } \\
\text { individual } \\
\text { dismissal }\end{array}$ & $\begin{array}{l}\text { Protection of workers is improved. Periods of } \\
\text { notice will be extended from 1989. Dismissal for } \\
\text { economic reasons will be possible only if work has } \\
\text { decreased significantly and permanently and if } \\
\text { employees cannot be transferred or trained for new } \\
\text { tasks. (pg. 120, 1989) }\end{array}$ & & $\begin{array}{l}\text { no data but } \\
\text { would qualify } \\
\text { if scoring } \\
\text { applied }\end{array}$ & -1 \\
\hline Finland & 1997 & $\begin{array}{l}\text { notice for } \\
\text { individual } \\
\text { dismissal }\end{array}$ & $\begin{array}{l}\text { In March 1996, several acts were submitted to the } \\
\text { parliament regarding labour market reform aimed } \\
\text { at stimulating new hiring... Employers' period of } \\
\text { notice has been shortened to one month (from two } \\
\text { months) and that for employees to fourteen days } \\
\text { (from one month)... (pg. 78, 1996) } \\
\text { Notice periods for employers and employees have } \\
\text { been halved, to one month and two weeks, } \\
\text { respectively (Pg. 63, 1997). }\end{array}$ & $\begin{array}{l}\text { pg. } 63, \\
1997\end{array}$ & yes in 1997 & 1 \\
\hline Greece & 2011 & $\begin{array}{l}\text { notice for } \\
\text { individual }\end{array}$ & $\begin{array}{l}\text { The following measures were introduced in } 2010 \\
\text { (Laws } 3863 / 2010 \text { and } 3899 / 2010 \text { ) to facilitate job }\end{array}$ & & yes in 2011 & 1 \\
\hline
\end{tabular}

\section{CInternational Monetary Fund. Not for Redistribution}




\begin{tabular}{|c|c|c|c|c|c|c|c|}
\hline & & $\begin{array}{l}\text { dismissal, } \\
\text { severance } \\
\text { pay, } \\
\text { collective } \\
\text { dismissal. }\end{array}$ & $\begin{array}{c}\text { reallocation: } \\
\text { - Reduction in notice period. The notice period } \\
\text { prior to dismissal of white collar workers has been } \\
\text { reduced substantially. For an employee working } \\
28 \text { years or more, for example, notification is } \\
\text { reduced to } 6 \text { from } 24 \text { months. The new provisions } \\
\text { lower total severance costs for white collar } \\
\text { workers with long tenure. Employers now have a } \\
\text { clear incentive to provide notice of dismissal for } \\
\text { workers with long tenure, in which case their } \\
\text { severance payments are halved. } \\
\text { - New rules for the settlement of severance } \\
\text { payments...make it possible for severance } \\
\text { payment, when it exceeds } 2 \text { months' pay, to be } \\
\text { paid in installments. } \\
\text { - Redefinition of collective dismissal rules. The } \\
\text { new law increases the threshold above which } \\
\text { dismissals are characterised as collective to } 6 \\
\text { employees for enterprises with } 20-150 \text { employees } \\
\text { and } 5 \% \text { or } 30 \text { employees for those with more than } \\
150 \text { employees. This compares with thresholds of } \\
4 \text { employees per month for enterprises with } 20-200 \\
\text { employees and } 2-3 \% \text { or } 30 \text { employees for } \\
\text { enterprises with more than } 200 \text { employees under } \\
\text { the } 2000 \text { law. } \\
\text { - Extension of probationary period. It was } \\
\text { extended from } 2 \text { months to } 1 \text { year. (pg. } 123,2011 \text { ) }\end{array}$ & & & & \\
\hline Greece & 2012 & $\begin{array}{c}\text { severance } \\
\text { pay }\end{array}$ & $\begin{array}{c}\text { The length of prior notice of dismissal has } \\
\text { been shortened to a maximum of four months, } \\
\text { compared to } 24 \text { months for white-collar } \\
\text { workers previously. The severance pay for } \\
\text { white-collar workers has been reduced and } \\
\text { subjected to a ceiling of } 12 \text { months' salary. } \\
\text { (pg. 50, 2013) }\end{array}$ & & & yes for 2012 & 1 \\
\hline Ireland & 1973 & $\begin{array}{c}\text { notice for } \\
\text { individual } \\
\text { dismissal }\end{array}$ & $\begin{array}{c}\text { Minimum Notice and Terms of Employment Act, } \\
\text { 1973, introduces and defines minimum notice } \\
\text { period for dismissal [see e.g. } \\
\text { http://www.irishstatutebook.ie/eli/1973/act/4/secti } \\
\text { on/4/enacted/en/html\#sec4] }\end{array}$ & & & $\begin{array}{l}\text { no data but } \\
\text { would qualify } \\
\text { if scoring } \\
\text { applied }\end{array}$ & -1 \\
\hline Ireland & 1977 & $\begin{array}{l}\text { procedural } \\
\text { inconvenie } \\
\text { nce, notice } \\
\text { for } \\
\text { individual } \\
\text { dismissal }\end{array}$ & $\begin{array}{l}\text { During the 1970s, extensive legislation was } \\
\text { enacted in Ireland to protect employees' rights and } \\
\text { conditions of employment. The most important of } \\
\text { these are the Protection of Employment Act } \\
\text { (1977), the Unfair Dismissals Act (1977) and the } \\
\text { Employment Equality Act ( 1977). (pg. 89, 1987) } \\
\text { [see } \\
\text { http://www.irishstatutebook.ie/eli/1977/act/7/enact } \\
\text { ed/en/html } \\
\begin{array}{c}\text { http://www.irishstatutebook.ie/eli/1977/act/10/ena } \\
\text { cted/en/html } \\
\text { http://www.irishstatutebook.ie/eli/1998/act/21/ena } \\
\text { cted/en/html] }\end{array}\end{array}$ & & & no data & -1 \\
\hline Ireland & 2006 & $\begin{array}{c}\text { notice for } \\
\text { individual } \\
\text { dismissal }\end{array}$ & $\begin{array}{c}\text { Revision of the } 1973 \text { Minimum Notice and Terms } \\
\text { of Employment Act (which had introduced and } \\
\text { defined minimum notice period for dismissal [see } \\
\text { e.g. } \\
\frac{\text { http://www.irishstatutebook.ie/eli//1973/act/4/secti }}{\text { on/4/enacted/en/html\#sec4] }}\end{array}$ & & & yes in 2006 & 1 \\
\hline Ireland & 2012 & $\begin{array}{l}\text { severance } \\
\text { pay }\end{array}$ & $\begin{array}{l}\text { Before } 2012 \text {, the Government paid a rebate to } \\
\text { employers for redundancy payouts to employees. } \\
\text { Up until } 1 \text { January } 2012 \text { this rebate amounted to } \\
\text { 60\%; between } 1 \text { January } 2012 \text { and } 1 \text { January } 2013 \text {, } \\
\text { the Government rebate was } 15 \% \text {; from } 2013 \\
\text { onwards the Government rebate was abolished } \\
\text { [see e.g. } \\
\frac{\text { https://www.eurofound.europa.eu/observatories/e }}{\text { mcc/erm/legislation/ireland-severance- }} \\
\text { payredundancy-compensation] }\end{array}$ & & & yes in 2012 & -1 \\
\hline Portugal & 1975 & $\begin{array}{l}\text { collective } \\
\text { dismissal }\end{array}$ & $\begin{array}{l}\text { Collective dismissal procedures become subject to } \\
\text { regulation. (pg. } 43,1976)\end{array}$ & $\begin{array}{c}\text { Where employment is } \\
\text { concerned, a law was } \\
\text { passed in December } 1974 \\
\text { which considerably } \\
\text { limited the possibility of } \\
\text { collective dismissals (pg. } \\
35,1976 \text { ) } \\
\end{array}$ & $\begin{array}{c}\text { pg. } 12, \\
1979 \\
\text { pg. } 67, \\
1989\end{array}$ & $\begin{array}{l}\text { no data but } \\
\text { would qualify } \\
\text { if scoring } \\
\text { applied }\end{array}$ & -1 \\
\hline
\end{tabular}




\begin{tabular}{|c|c|c|c|c|c|c|c|}
\hline Portugal & 1976 & $\begin{array}{l}\text { procedural } \\
\text { inconvenie } \\
\text { nce }\end{array}$ & $\begin{array}{l}\text {...to combat the rise in unemployment caused by } \\
\text { the domestic and international recession and by the } \\
\text { return of expatriates from the former colonies, the } \\
\text { authorities enacted legislation virtually prohibiting } \\
\text { all dismissals (pg. } 9,1976 \text { ) }\end{array}$ & & $\begin{array}{c}\text { pg. } 12, \\
1979 \\
\text { pg. } 67, \\
1989\end{array}$ & $\begin{array}{l}\text { no data but } \\
\text { would qualify } \\
\text { if scoring } \\
\text { applied }\end{array}$ & -1 \\
\hline Portugal & 1978 & $\begin{array}{l}\text { procedural } \\
\text { inconvenien } \\
\text { ce }\end{array}$ & $\begin{array}{l}\text { August 29: Authorisation for firms to suspend } \\
\text { work contracts on account of economic } \\
\text { difficulties. (pg. 40, 1977) }\end{array}$ & & & $\begin{array}{l}\text { no data but } \\
\text { would qualify } \\
\text { if scoring } \\
\text { applied }\end{array}$ & 1 \\
\hline Portugal & 1990 & $\begin{array}{l}\text { procedural } \\
\text { inconvenie } \\
\text { nce }\end{array}$ & $\begin{array}{l}\text { the possibility of dismissal for failure to fulfill job } \\
\text { requirements (pg. 19, 1992) }\end{array}$ & & $\begin{array}{l}\text { pg. } 94, \\
1996\end{array}$ & yes in 1990 & 1 \\
\hline Portugal & 1992 & $\begin{array}{l}\text { procedural } \\
\text { inconvenie } \\
\text { nce }\end{array}$ & $\begin{array}{l}\text { Changes in both layoff legislation and legal } \\
\text { framework governing collective labour contracts } \\
\text { aim at making labour markets more flexible. (pg. } \\
992,1993 \text { ) }\end{array}$ & & & yes in 1992 & 1 \\
\hline Portugal & 2004 & $\begin{array}{c}\text { procedural } \\
\text { inconvenie } \\
\text { nce }\end{array}$ & $\begin{array}{l}\text { The new Labour Code (Código do Trabalho), } \\
\text { which came into force in December 2003, replaces } \\
\text { individual and collective labour legislation with a } \\
\text { unified text, deemed to be clearer and easier to } \\
\text { apply...employers now have the right to oppose } \\
\text { the reinstatement of workers in dismissal cases } \\
\text { under certain conditions, such as in cases where it } \\
\text { would harm or disrupt business activity. (pg. 78- } \\
\qquad 79,2004 \text { ) } \\
\text { In the case of regular contracts, the } 2003 \text { changes } \\
\text { eased somewhat the procedures for collective } \\
\text { dismissal: the deadlines for initiating negotiations } \\
\text { and taking the final decision were shortened; the } \\
\text { priority given to trade union representatives and } \\
\text { members of workers councils was eliminated. (pg. } \\
128,2008 \text { ) }\end{array}$ & & & yes in 2004 & 1 \\
\hline Portugal & 2010 & $\begin{array}{l}\text { procedural } \\
\text { inconvenie } \\
\text { nce, notice } \\
\quad \text { for } \\
\text { individual } \\
\text { dismissal, } \\
\text { severance } \\
\text { pay } \\
\end{array}$ & $\begin{array}{l}\text { The introduction of the new labour code in } 2009 \text {, } \\
\text { by reducing EPL for regular contracts, is an } \\
\text { important step in the direction of reducing labour } \\
\text { market dualism (pg. } 42,2010 \text { ) }\end{array}$ & $\begin{array}{l}\text {... an important step in the } \\
\text { direction of reducing } \\
\text { labour market dualism } \\
\text { (pg. } 42,2010)\end{array}$ & $\begin{array}{l}\text { pg. } 33 \text {, } \\
2012\end{array}$ & yes in 2010 & 1 \\
\hline Spain & 1978 & $\begin{array}{l}\text { procedural } \\
\text { inconvenie } \\
\text { nce }\end{array}$ & $\begin{array}{l}\text { A Decree-Law of 4th March, } 1977 \text { made the } \\
\text { regulations governing dismissals...considerably } \\
\text { more flexible (pg. 13, 1977) } \\
\text {..legislation on layoffs, which is currently very } \\
\text { restrictive, will be made more flexible, and } \\
\text { employers will be allowed to lay off up to } 5 \text { per } \\
\text { cent of their workforce... (pg. 34, 1978) }\end{array}$ & & $\begin{array}{l}\text { pg. } 34, \\
1978 \\
\text { pg. } 27, \\
1982\end{array}$ & no data & 1 \\
\hline Spain & 1981 & $\begin{array}{l}\text { procedural } \\
\text { inconvenie } \\
\text { nce, } \\
\text { collective } \\
\text { dismissals }\end{array}$ & $\begin{array}{l}\text { The new Workers Statute...changed legal } \\
\text { framework provides in particular for liberalisation } \\
\text { of dismissals... (pg. 27, 1981) }\end{array}$ & $\begin{array}{c}\text { Two important laws were } \\
\text { enacted in 1980. The new } \\
\text { Workers Statute... (pg. 27, } \\
\text { 1981) } \\
\text {... it was not until the } \\
\text { promulgation of the } \\
\text { Workers' Statute in } 1980 \\
\text { that a comprehensive } \\
\text { reform of labour law took } \\
\text { place. (pg. 27, 1982) }\end{array}$ & $\begin{array}{l}\text { pg. 27, } \\
1982\end{array}$ & no data & 1 \\
\hline Spain & $\begin{array}{c}\text { mid- } \\
1994 / 199 \\
5\end{array}$ & $\begin{array}{l}\text { procedural } \\
\text { inconvenie } \\
\text { nce, } \\
\text { collective } \\
\text { dismissals }\end{array}$ & $\begin{array}{l}\text { The draft law simplifies layoff procedures. } \\
\text { Dismissal of a small number of workers (treated as } \\
\text { if they were individual dismissals) would no } \\
\text { longer require prior consultation with workers' } \\
\text { representatives and administrative authorization. } \\
\text { (pg. 81, 1994) } \\
\text {...the Government has presented a draft law } \\
\text { modifying existing labour legislation } \\
\text { significantly... Layoffs of permanent employees } \\
\text { will be made much easier, notably by abolishing in } \\
\text { many cases the requirement of administrative } \\
\text { authorization. (pg. } 88-89,1994 \text { ) }\end{array}$ & $\begin{array}{l}\text {... far-reaching labor } \\
\text { market reforms aimed at } \\
\text { lifting barriers to job } \\
\text { creation. A decree was } \\
\text { passed at the end of } 1993 \\
\text { and a draft has been } \\
\text { presented to Parliament } \\
\text { and is expected to become } \\
\text { law by the middle of } 1994 . \\
\text { (pg. 80, 1994) } \\
\text { This draft law breaks with } \\
\text { the corporatist philosophy } \\
\text { of past legislation and is } \\
\text { expected to increase } \\
\text { labour market flexibility } \\
\text { considerably. (pg. } 88-89, \\
\text { 1994) }\end{array}$ & & yes for 1995 & 1 \\
\hline
\end{tabular}

\section{CInternational Monetary Fund. Not for Redistribution}




\begin{tabular}{|c|c|c|c|c|c|c|c|}
\hline Spain & 1998 & $\begin{array}{l}\text { severance } \\
\text { pay }\end{array}$ & $\begin{array}{l}\text { Employers and trade unions agree on a labour } \\
\text { market reform which would encourage the creation } \\
\text { of indefinite-term jobs. Inter alia, it calls for the } \\
\text { introduction of a new type of indefinite-term } \\
\text { contract with reduced redundancy costs for certain } \\
\text { groups of workers, a new definition of the grounds } \\
\text { for economic redundancies and proposals for } \\
\text { improving the collective bargaining process. (pg. } \\
179,1998 \text { ) }\end{array}$ & $\begin{array}{c}\text {..The social partners have } \\
\text { taken an important step... } \\
\text { (pg. } 76,1998 \text { ) }\end{array}$ & $\begin{array}{c}\text { pg. } 57 \text {, } \\
2000 \\
\text { pg. } 66- \\
68,165, \\
2001 \\
\text { pg. } 101, \\
2010\end{array}$ & no & 1 \\
\hline Spain & 2002 & $\begin{array}{l}\text { procedural } \\
\text { inconvenie } \\
\text { nce, } \\
\text { severance } \\
\text { pay }\end{array}$ & $\begin{array}{l}\text { New measures taken in early } 2001 \text { have broadened } \\
\text { the } 1997 \text { reform... (pg. } 65-66,2001 \text { ) } \\
\text { In March } 2001 \text { the government approved a } \\
\text { deepening of the } 1997 \text { labour market reform. The } \\
\text { measures adopted include: } \\
\text { - An extension of the new permanent contract } \\
\text { introduced in the } 1997 \text { labour market } \\
\text { reform beyond May 2001. } \\
\text { - The permanent contract with reduced firing costs } \\
\text { will continue to apply to specific } \\
\text { groups (workers aged 18-29, workers with a } \\
\text { temporary contract, workers aged over } 45 \text {, } \\
\text { workers that have been unemployed for more than } \\
\text { one year, women in some professions), } \\
\text { and has been extended to young workers (now } \\
\text { defined as those aged between } \\
16 \text { and } 30 \text { ), long-term unemployed (for more than } \\
6 \text { months), unemployed women in } \\
\text { sectors where they are underrepresented (most of } \\
\text { them) and disabled workers... (pg. 66, 2003) }\end{array}$ & & $\begin{array}{l}\text { pg. } 66, \\
2003\end{array}$ & no & 1 \\
\hline Spain & 2011 & $\begin{array}{l}\text { severance } \\
\text { pay }\end{array}$ & $\begin{array}{l}\text { The labour market reform, approved in September } \\
\text { 2010...aims to reduce the upper range of dismissal } \\
\text { costs for permanent contracts and to smooth the } \\
\text { difference in dismissal costs between temporary } \\
\text { and permanent contracts: } \\
\text { - First, the law aims to make it easier for firms to } \\
\text { have dismissals accepted by the courts } \\
\text { as justified. If this reform is effective, it will } \\
\text { reduce severance payment of firms } \\
\text { substantially, from the current practice of } 45 \text { days' } \\
\text { wages to } 20 \text { days' wages. } \\
\text { - Second, it broadens the base for which the } \\
\text { permanent contract with reduced severance } \\
\text { payment of } 33 \text { days' wages can be applied and } \\
\text { guarantees that this reduced severance } \\
\text { pay also applies now in cases where firms would } \\
\text { prefer to declare the dismissal upfront } \\
\text { as "unjustified" (to avoid litigation). } \\
\text { - Third, the introduction of a capital-funded } \\
\text { component, similar to the one introduced in } \\
\text { the framework of the Austrian severance pay } \\
\text { reform, further reduces the onetime } \\
\text { costs of dismissal. (pg. 103, 2010) }\end{array}$ & $\begin{array}{l}\text { The recent reform } \\
\text { represents significant } \\
\text { progress... } \\
\text { The recent reform adopted } \\
\text { by Parliament in } \\
\text { September } 2010 \text { should } \\
\text { lead to significant } \\
\text { progress... (pg. 101, } \\
\text { 2010) }\end{array}$ & & yes for 2011 & 1 \\
\hline Spain & 2013 & $\begin{array}{l}\text { procedural } \\
\text { inconvenie } \\
\text { nce, } \\
\text { severance } \\
\text { pay, } \\
\text { collective } \\
\text { dismissals }\end{array}$ & $\begin{array}{l}\text { The } 2012 \text { labour market reform aims to reduce } \\
\text { further the duality in the Spanish labour market, } \\
\text { with a reform of employment protection } \\
\text { legislation...: } \\
\text { - The law redefines the economic reasons for } \\
\text { dismissal, further clarifying the conditions } \\
\text { under which a dismissal for objective reasons } \\
\text { could be justified. In this case, the } \\
\text { employer pays } 20 \text { days' wages of severance pay } \\
\text { per year of seniority. } \\
\text { - If a dismissal is judged unjustified, the } \\
\text { maximum severance pay is reduced to } 33 \text { days' } \\
\text { wages per year of seniority up to a maximum of } 24 \\
\text { months, compared with } 45 \text { days and } \\
\text { a maximum of } 42 \text { months on the regular } \\
\text { permanent contract before. This applies to all } \\
\text { new contracts and for future years of service on } \\
\text { existing contracts. } \\
\text { - The law eliminates the need for administrative } \\
\text { authorisation of collective dismissal, in } \\
\text { line with current regulations in most European } \\
\text { countries. } \\
\text { - While it removes the option of express } \\
\text { dismissal, according to which firms could declare } \\
\text { the dismissal upfront as being "unjustified" and } \\
\text { pay } 45 \text { days' wages per year of seniority }\end{array}$ & $\begin{array}{l}\text {...these reforms are a } \\
\text { substantial step in the right } \\
\text { direction... } \\
\text { A potentially important } \\
\text { part of the reform is } \\
\text { clarifying what justified } \\
\text { dismissal means... (pg. } 34, \\
\text { 2012) }\end{array}$ & $\begin{array}{c}\text { pg. } 40, \\
92,2014\end{array}$ & yes for 2013 & 1 \\
\hline
\end{tabular}

\section{CInternational Monetary Fund. Not for Redistribution}




\begin{tabular}{|c|c|c|c|c|c|c|}
\hline & & & $\begin{array}{l}\text { to avoid litigation, firms no longer are obliged to } \\
\text { pay interim wages during the period } \\
\text { the case is adjudicated. } \\
\text { - The law introduces a new type of permanent } \\
\text { contract for companies with fewer than } \\
50 \text { employees. Hiring on this new contract is } \\
\text { subject to an extended trial period of one year, } \\
\text { compared with a previous maximum of six } \\
\text { months, and various tax credits. (pg. } 98,2012 \text { ) }\end{array}$ & & & \\
\hline Australia & 2006 & $\begin{array}{c}\text { procedural } \\
\text { inconvenie } \\
\text { nce }\end{array}$ & $\begin{array}{l}\text { The Workplace Relations Amendment (Work } \\
\text { Choices) Act } 2005 \text { took effect in the first quarter } \\
\text { of } 2006 \text { and sought to reinforce employers' } \\
\text { prerogatives at the expense of employees (pg. } 81 \text {, } \\
\text { 2012) }\end{array}$ & & yes for 2007 & 1 \\
\hline Australia & 2010 & $\begin{array}{l}\text { procedural } \\
\text { inconvenie } \\
\text { nce, notice } \\
\text { for } \\
\text { individual } \\
\text { dismissal }\end{array}$ & $\begin{array}{l}\text { Work Choices removed unfair dismissal } \\
\text { protections for employees of firms with fewer than } \\
100 \text { employees. The Fair Work Act restored these } \\
\text { protections subject to minimum qualifying periods } \\
\text { of one-year service for workers in firms with fewer } \\
\text { than } 15 \text { employees and six months' service for } \\
\text { workers in firms with } 15 \text { or more employees. In } \\
\text { addition, a number of protections previously } \\
\text { available under Work Choices were streamlined } \\
\text { and broadened in the FW Act to protect workers } \\
\text { against discrimination and adverse actions because } \\
\text { they have a workplace right. (pg. } 83-84,2012)\end{array}$ & & yes for 2010 & -1 \\
\hline $\begin{array}{c}\text { New } \\
\text { Zealand }\end{array}$ & 2001 & $\begin{array}{c}\text { procedural } \\
\text { inconvenie } \\
\text { nce }\end{array}$ & $\begin{array}{l}\text { The new Employment Relations Act...modifies } \\
\text { provisions under the ECA in several significant } \\
\text { ways... The ERA proposes to avoid undue } \\
\text { litigation by making mediation a mandatory first } \\
\text { step. If there is no resolution, the parties can then } \\
\text { turn to the Employment Relations Authority, a } \\
\text { new investigative body. If the parties do not agree } \\
\text { with its ruling, or if the Authority so decides, } \\
\text { grievances and disputes are then turned over to an } \\
\text { Employment Court. It can redirect the matter back } \\
\text { to mediation, to the Authority or make a final } \\
\text { judgement. (pg. } 78-79,2000 \text { ) }\end{array}$ & $\begin{array}{l}\text { pg. } 83 \text {, } \\
2002 \\
\text { pg. } 98, \\
2005 \\
\text { pg. } 117, \\
2013\end{array}$ & yes for 2001 & -1 \\
\hline $\begin{array}{c}\text { New } \\
\text { Zealand }\end{array}$ & 2012 & & $\begin{array}{l}\text { The Employment Relations Act } 2000 \text { was } \\
\text { amended to extend trial period provisions (for up } \\
\text { to } 90 \text { days) from firms with fewer than } 20 \\
\text { employees to all firms on } 1 \text { April } 2011 \ldots \text { (pg. } 56 \text {, } \\
\text { 2011) }\end{array}$ & & yes for 2012 & 1 \\
\hline Korea & 1998 & $\begin{array}{l}\text { procedural } \\
\text { inconvenie } \\
\text { nce, notice } \\
\text { for } \\
\text { individual } \\
\text { dismissal, } \\
\text { collective } \\
\text { dismissals }\end{array}$ & $\begin{array}{l}\text { The March } 1997 \text { labour law reform eased } \\
\text { restrictions on layoffs by expressly allowing } \\
\text { dismissals for "urgent managerial reasons", while } \\
\text { specifying certain requirements that must be } \\
\text { fulfilled beforehand by management... the } \\
\text { Tripartite Commission agreed that it should be } \\
\text { implemented in February } 1998 \text { to help firms } \\
\text { restructure in the wake of the crisis... (pg. 166, } \\
\text { 1998) }\end{array}$ & $\begin{array}{l}\text { pg. } 142, \\
2005 \\
\text { pg. } 127, \\
2008 \\
\text { pg. } 129, \\
2012\end{array}$ & yes for 1998 & 1 \\
\hline $\begin{array}{c}\text { Czech } \\
\text { Republic }\end{array}$ & 2007 & $\begin{array}{c}\text { procedural } \\
\text { inconvenie } \\
\text { nce }\end{array}$ & $\begin{array}{l}\text { A new labour code was passed by the lower } \\
\text { chamber of the parliament in early } 2006 \text {. The code, } \\
\text { if implemented, will allow a wider scope of } \\
\text { employment contracts because it takes an "anglo- } \\
\text { saxon" rather than "Napoleonic" legal form... (pg. } \\
\text { 36, 2006) [NB: Amended Labor Code Act } \\
\text { (No.262) eventually became law, see e.g. } \\
\text { http://www.mpsv.cz/files/clanky/3221/Labour Co } \\
\text { de_2012.pdf] }\end{array}$ & & yes for 2007 & 1 \\
\hline $\begin{array}{c}\text { Czech } \\
\text { Republic }\end{array}$ & 2012 & $\begin{array}{c}\text { notice } \\
\text { period, } \\
\text { severance } \\
\text { pay }\end{array}$ & $\begin{array}{l}2012 \text { revision of labor code with effect from } \\
\text { January } 1 \text { st } 2012 \text { [see e.g. } \\
\text { https://ec.europa.eu/europeaid/employment-labor- } \\
\text { and-social-protection-social-reforms-czech- } \\
\text { republic_en } \\
\text {..it has...introduced wider possibilities for } \\
\text { employers to terminate the employment...The } \\
\text { maximum duration of the probationary period } \\
\text { extended to } 6 \text { months for executive employees...] }\end{array}$ & & yes for 2012 & 1 \\
\hline
\end{tabular}




\begin{tabular}{|c|c|c|c|c|c|}
\hline $\begin{array}{c}\text { Slovak } \\
\text { Republic }\end{array}$ & 2004 & $\begin{array}{c}\text { notice } \\
\text { period, } \\
\text { severance } \\
\text { pay }\end{array}$ & $\begin{array}{l}\text { Major amendments to the Labour Code were } \\
\text { adopted in June } 2003 \text { and became effective as of } 1 \\
\text { July } 2003 . . \text { More flexibility is introduced as } \\
\text { regards an employer's right to terminate an } \\
\text { employee's contract. When terminating an } \\
\text { employment contract the employer is obliged to } \\
\text { specify the reasons for termination. These are } \\
\text { more extensive than previously allowed... In all } \\
\text { cases the statutory notice period is reduced to two } \\
\text { months regardless of the reason for termination. } \\
\text { An employee working for the same employer for } \\
\text { more than five years shall be given } 3 \text {-months } \\
\text { notice... (pg. 121-122, 2004) }\end{array}$ & $\begin{array}{c}\text { yes for } 2003- \\
2004\end{array}$ & 1 \\
\hline $\begin{array}{c}\text { Slovak } \\
\text { Republic }\end{array}$ & 2012 & $\begin{array}{c}\text { notice } \\
\text { period, } \\
\text { severance } \\
\text { pay }\end{array}$ & $\begin{array}{l}\text { Amendments to the "new" } 2003 \text { labor code that } \\
\text { eases legislation on regular contracts (shortening } \\
\text { of length of notice period). [For details, see } \\
\text { e.g.http://www.ilo.org/dyn/eplex/docs/50/labour- } \\
\text { code-full-wording-january-2012.pdf] }\end{array}$ & yes for 2012 & 1 \\
\hline
\end{tabular}

Figure A1.1. Distribution of major employment protection legislation reforms over time

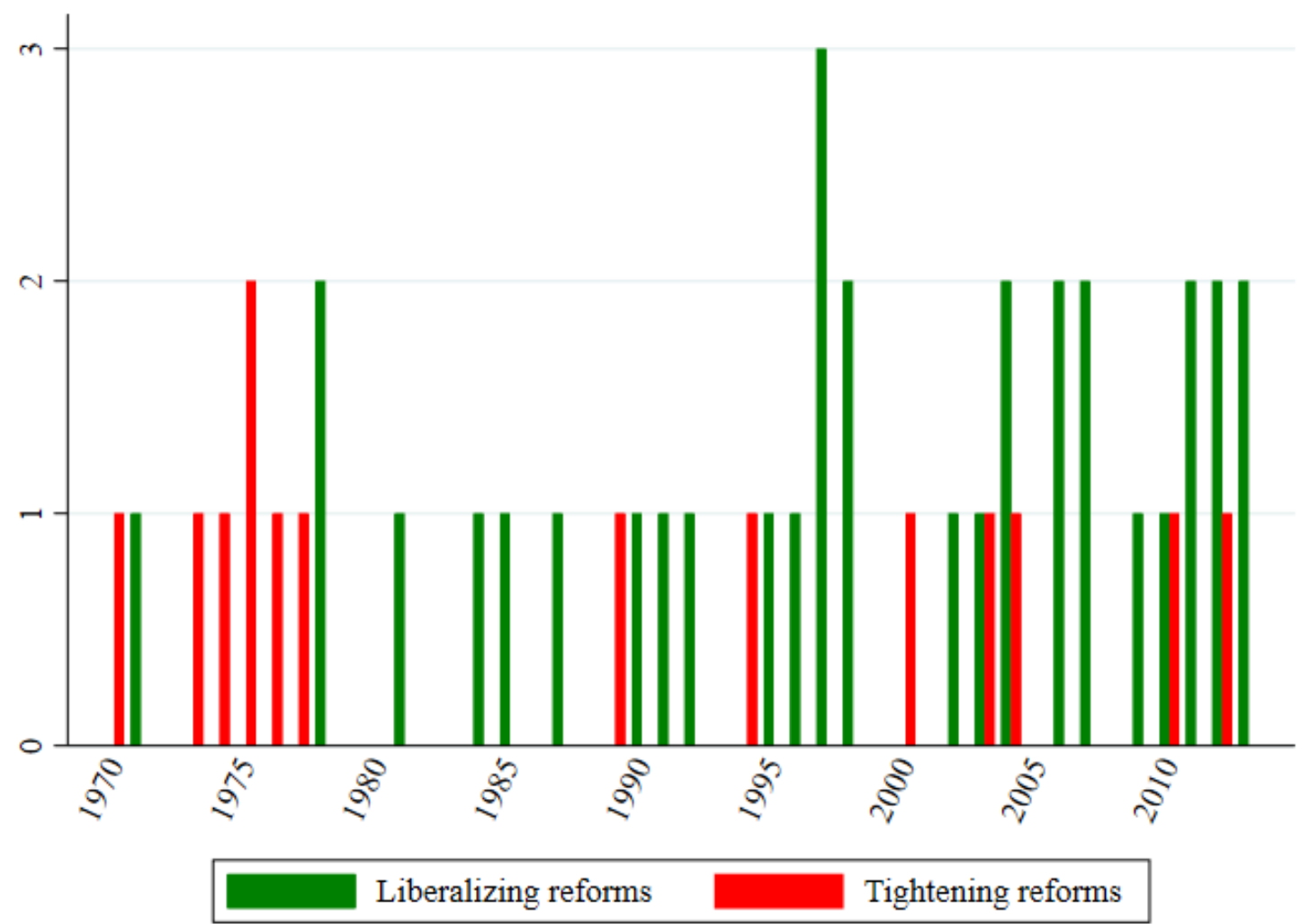

Notes: The Figure reports the total number (y-axis) of reforms to employment protection legislation implemented across all countries in the sample by year (x-axis). 


\section{Appendix 2. Layoff Rates}

We use data contained in the 2014 Displaced Workers Survey (DWS), conducted in the context of the more comprehensive IPUMS-CPS (see Flood et al., 2017). The survey covers around ninety thousand individuals and provides information about (i) whether the individual held at least one job in the last three years, (ii) the industry of the current or last job, (iii) whether the individual was displaced in the last three years, (iv) the reason for the displacement, and (v) the industry in which the worker was employed when she/he was displaced. Using this information, for each industry we compute the total number of workers that were displaced for either of the following three reasons: (a) the plant or company closed or moved, (b) work was insufficient, (c) the position or shift was abolished. We do so for each of the three years covered in the survey (2011, 2012 and 2013). Since individuals were only asked in which industry they were employed in January 2014, we use data from the U.S. Bureau of Labor Statistics (BLS) to compute industry-level employment changes in 2014, relative to 2011, 2012 and 2013, and multiply them by the employment level in 2014 to obtain employment levels for each year covered by the survey. Table A2.1 below reports the layoff rates we computed in this way. 
Table A2.1. Layoff rates

\begin{tabular}{|c|c|c|c|c|c|}
\hline & 2011 & 2012 & 2013 & Average & $\begin{array}{c}\text { Industry } \\
\text { code }\end{array}$ \\
\hline Food, Beverages \& Tobacco & 3.04 & 1.99 & 4.07 & 3.03 & $10 \mathrm{t} 12$ \\
\hline Textiles & 2.18 & 3.10 & 5.92 & 3.73 & $13 \mathrm{t} 15$ \\
\hline Wood, Paper \& Reproduction & 4.31 & 3.21 & 3.90 & 3.81 & $16 \mathrm{t} 18$ \\
\hline Coke \& Refined Petroleum & 0.00 & 0.00 & 3.21 & 1.07 & 19 \\
\hline Chemicals & 3.43 & 2.11 & 2.18 & 2.58 & $20 \mathrm{t} 21$ \\
\hline Rubber \& Plastics & 2.82 & 2.22 & 2.17 & 2.41 & $22 \mathrm{t} 23$ \\
\hline Basic Metals & 2.44 & 3.35 & 3.92 & 3.24 & $24 \mathrm{t} 25$ \\
\hline Electrical \& Optical & 4.67 & 5.96 & 6.25 & 5.62 & $26 \mathrm{t} 27$ \\
\hline Machinery \& Equipment & 3.04 & 2.39 & 3.15 & 2.86 & 28 \\
\hline Transport Equipment & 2.94 & 2.00 & 3.37 & 2.77 & $29 \mathrm{t} 30$ \\
\hline Others Manufacturing & 8.54 & 7.48 & 5.92 & 7.31 & $31 \mathrm{t} 33$ \\
\hline Wholesale \& Retail, Motor vehicles & 2.30 & 2.18 & 2.48 & 2.32 & 45 \\
\hline Wholesale ex. Motor Vehicles & 1.85 & 2.84 & 3.39 & 2.69 & 46 \\
\hline Retail ex. Motor Vehicles & 2.04 & 2.46 & 3.22 & 2.57 & 47 \\
\hline Transport \& Storage & 2.48 & 2.92 & 3.41 & 2.94 & $49 \mathrm{t} 52$ \\
\hline Postal \& Courier & 1.58 & 1.40 & 1.34 & 1.44 & 53 \\
\hline Publishing \& Audiovisual & 2.70 & 2.56 & 4.36 & 3.21 & $58 \mathrm{t} 60$ \\
\hline Telecommunications & 2.08 & 1.81 & 2.05 & 1.98 & 61 \\
\hline$I T \&$ Others & 2.47 & 3.14 & 3.69 & 3.10 & $62 \mathrm{t} 63$ \\
\hline Agriculture & 0.00 & 5.20 & 5.62 & 3.61 & A \\
\hline Mining \& Quarrying & l & l & / & l & $\mathrm{B}$ \\
\hline Utilities & 1.14 & 2.21 & 1.43 & 1.59 & DtE \\
\hline Construction & 4.51 & 5.63 & 8.98 & 6.37 & $\mathrm{~F}$ \\
\hline Accommodation \& Food Services & 1.96 & 2.86 & 4.43 & 3.08 & I \\
\hline Financial \& Insurance & 2.51 & 1.93 & 2.59 & 2.34 & $\mathrm{~K}$ \\
\hline Real Estate & 1.28 & 1.53 & 2.91 & 1.90 & $\mathrm{~L}$ \\
\hline Professional \& Support Activities & 2.62 & 3.59 & 4.84 & 3.68 & $\mathrm{MtN}$ \\
\hline$P A$, Defense \& SS & l & l & / & / & $\mathrm{O}$ \\
\hline Education & 0.90 & 1.43 & 1.72 & 1.35 & $\mathrm{P}$ \\
\hline Health \& Social & 1.31 & 1.50 & 2.54 & 1.78 & Q \\
\hline Arts \& Recreation & 2.06 & 2.81 & 5.33 & 3.40 & $\mathrm{R}$ \\
\hline Other Service Activities & 1.85 & 2.61 & 3.72 & 2.73 & $\mathrm{~S}$ \\
\hline Average & 2.50 & 2.81 & 3.74 & 3.02 & 1 \\
\hline
\end{tabular}




\section{Appendix 3. Elasticities of Substitution}

Let there be an aggregate production function under which gross output is produced using, among others, labor and capital as inputs. That is, $Y=H\left(K, L, X_{i}, A\right)$, where $\mathrm{K}$ and $\mathrm{L}$ stand respectively for the flow of capital and labor services, $X_{i}$ are other inputs and $\mathrm{A}$ is an index denoting technical efficiency. Assuming further that the change in technical efficiency is Hicks-neutral and capital and labor are weakly separable from other inputs, we can rewrite the production function as $Y=A J\left(X_{i}, F(K, L)\right)$, where $F(K, L)$ denotes the aggregate input. Next, we characterize $F$ as a constant elasticity of substitution production function:

$$
Y=F(K, L)=\left(\alpha(K)^{\varepsilon}+(1-\alpha)(L)^{\varepsilon}\right)^{1 / \varepsilon}
$$

Profit maximization implies the familiar condition equating the price of capital to its marginal product expressed in similar units:

$$
P^{K}=P F_{K}(K, L)
$$

where $P^{K}$ is the price of capital services and $P$ is the price of the aggregate input $F(K, L)$. Using $F_{K}(K, L)=\alpha K^{\varepsilon-1} F(K, L)^{1-\varepsilon}$ this equation can be rewritten as:

$$
\frac{P^{K}}{P}=\alpha\left(\frac{F(K, L)}{K}\right)^{1-\varepsilon}
$$

Notice that $1-\varepsilon$ is the inverse of the EOS $(1-\varepsilon=1 / \sigma)$. Hence, taking logs and adding a disturbance term that captures potential errors in the firm optimization process, the EOS can be estimated from the following equation:

$$
\ln \left(\frac{P_{j, t}^{K}}{P_{j, t}}\right)=\ln \left(\alpha_{j}\right)+\frac{1}{\sigma} \ln \left(\frac{F_{j, t}\left(K_{j, t} L_{j, t}\right)}{K_{j, t}}\right)+\epsilon_{j, t}
$$

where we added the subscripts $j$ and $t$ to indicate country and time.

We estimate Equation (A3.1) separately for each industry using OLS. For the data, we rely on the EU KLEMS 2017 database (see Jäger, 2017). This readily provides estimates of the flow of capital services, which is computed applying geometric depreciation rates-which are estimated by KLEMS and differ by capital asset and industry) to the capital stock data (taken from Eurostat). For a sensitivity analysis we also estimate a set of EOS using data on the real capital stock to proxy for the flow of capital services. Ideally, for the aggregate input we would need some measure of value added deflated by technical change. Lacking a measure of 
technical change, we use data on value added (volumes and prices) as proxies. These are contained in the EU KLEMS 2017 database and are consistent with Eurostat.

To obtain an estimate of the rental price of capital services we follow two alternative approaches. One assumes that the rental rate is proportional to the price of capital services; this is the approach followed, among others, by Baccianti (2013). In this case, we simply divide the nominal capital stock by the volume of capital services and use that as the rental rate. Our second, and preferred concept, is the "Jorgensonian" rental rate, which also accounts for the depreciation of capital and the opportunity cost of the investment. Following Jorgenson (1963), we assume that in equilibrium an investor is indifferent between (i) buying a unit of capital at price $q_{t-1}^{k}$, earning a rental fee $P_{t}^{k}$, and selling the depreciated end of period capital to get $q_{t}^{k}\left(1-\delta^{k}\right)$, or (ii) earning a nominal interest rate $i_{t-1}$ on a different investment opportunity. ${ }^{12}$ Hence, we calculate the rental price of capital, for each industry-country-year observation, as: ${ }^{13}$

$$
P_{i, j, t}^{k}=q_{i, j, t-1}^{k} i_{j, t-1}+\delta_{i}^{k} q_{i, j, t}^{k}-\left(q_{i, j, t}^{k}-q_{i, j, t-1}^{k}\right)
$$

For the nominal interest rate, $i_{j, t}$, we follow O'Mahony and Timmer (2009) to derive an internal rate of return of capital as a residual of capital compensation, depreciation and capital gains. In practice, we calculate $i_{i, j, t}$, as:

$$
i_{i, j, t}=\frac{P_{i, t}^{K} K_{i, j, t}+\sum_{k}\left(q_{i, j, t}^{k}-q_{i, j, t-1}^{k}\right) A_{i, j, t}^{k}-\sum_{k} \delta_{i}^{k} q_{i, j, t}^{k} A_{i, j, t}^{k}}{\sum_{k} q_{i, j, t-1}^{k} A_{i, j, t}^{k}}
$$

where $A_{i, j, t}^{k}$ is the capital stock for asset $k$, in country $j$, industry $i$, at time $t$, and $P_{i, t}^{K} K_{i, j, t}$ is total capital compensation (calculated as value added minus labor compensation). ${ }^{14}$

\footnotetext{
${ }^{12}$ We do not account for the impact of taxation.

${ }^{13}$ Notice that $P_{i, j, t}^{k}$ is calculated for each different type of capital asset $k$ covered in the EU KLEMS 2017 database: (i) residential structures, (ii) total non-residential investment, (iii) transport equipment, (iv) computing equipment, (v) communications equipment, (vi) other machinery and equipment, (vii) cultivated assets, (viii) other intellectual property products, (ix) research and development, and (x) computer and software database. To obtain a measure of the industry-wide price of capital, $P_{i, j, t}^{K}$, the price of each asset is multiplied its relative share in capital services and the sum is used as the aggregate price of capital.

${ }^{14}$ An alternative (ex-ante) approach would be to use an exogenous measure for the rate of return, such as government bond interest rates plus a default risk premium. The (ex-post) approach we use does not require us to estimate risk premia and has the further advantage of ensuring consistency between income and production accounts and allows us to obtain countryindustry-specific measures of the interest rate. See O’Mahony and Timmer (2009) for more details.
} 
Due to the limited availability of capital stock and services data in the EU KLEMS database, the estimation is restricted to a sample of 13 countries. ${ }^{15}$

One potential concern in estimating Equation (A3.1) through OLS is that the variables might be non-stationary. If this were to be the case, the estimation would yield biased and inconsistent estimates. To deal with potential non-stationarity, we estimate Equation (A3.1) in first differences. ${ }^{16}$

As observed by Antràs (2004), EOS estimates derived from Equation (A3.1) might be biased if the assumption of Hicks-neutral technical change does not hold in practice. Therefore, we also relax this assumption and estimate a set of EOS from a production function allowing for labor- $\left(A^{l}\right)$ and capital- $A^{k}$ augmenting technical change. Following the literature, we assume those to grow at constant rates $\tau^{l}$ and $\tau^{k}$, respectively. The aggregate input is then produced according to:

$$
Y=F\left(K, L, A^{k}, A^{l}\right)=\left(\alpha\left(A_{0}^{k} e^{\tau^{k} t} K\right)^{\varepsilon}+(1-\alpha)\left(A_{0}^{l} e^{\tau^{l} t} L\right)^{\varepsilon}\right)^{1 / \varepsilon}
$$

Taking the first-order condition equating the price of capital to its marginal product and after simple manipulations, we can estimate the EOS, $\sigma$, from the following equation:

$$
\ln \left(\frac{P_{j, t}^{K}}{P_{j, t}}\right)=\ln \left(\alpha_{j}\right)+\left(\frac{1-\sigma}{\sigma}\right) \ln \left(A_{0}^{k}\right)+\frac{1}{\sigma} \ln \left(\frac{F_{j, t}\left(K_{j, t}, L_{j, t}\right)}{K_{j, t}}\right)+\left(\frac{1-\sigma}{\sigma}\right) \tau^{k} t+\epsilon_{j, t}
$$

Practically, this amounts to adding a linear trend to Equation (A3.1).

These various approaches, which rely on different assumptions regarding the capital stock, the user cost of capital and the form of technical change, yield four alternative sets of EOS that are reported in Table A3.1 below. The correlation among them ranges from 0.4 to 0.9 . On average, our estimated EOS are below one in all four cases, going from 0.68 (when we allow for labor- and capital- augmenting technical change) to 0.85 (when we divide the nominal capital stock by capital services to obtain the rental rate of capital). The EOS is estimated to

\footnotetext{
15 These countries are: Austria, Czech Republic, Denmark, Finland, France, Germany, Italy, Luxembourg, the Netherlands, Slovak Republic, Spain, Sweden and the United Kingdom.

${ }^{16}$ Another concern is that the regressor in Equation (A3.1) might be endogenous, as it represents the firms' demand for capital. To deal with potential endogeneity Antràs (2004), who estimates an EOS for the aggregate U.S. economy, employs an IV strategy, using the stock of capital owned by the government as an instrument for capital services. Formulating an IV strategy is more problematic in our context, since we estimate industry-specific EOS in a panel of countries. We proceed using OLS.
} 
exceed 1 for just 4 to 6 industries. Our baseline set of EOS (EOS1) are those that assume Hicksneutral technical change, use capital services data and calculate the rental rate following Jorgenson (1963). The other sets of EOS are used for sensitivity analyses. 
Table A3.1 Elasticities of substitution

\begin{tabular}{|c|c|c|c|c|c|}
\hline & EOS1 & EOS2 & EOS3 & EOS4 & $\begin{array}{l}\text { Industry } \\
\text { code }\end{array}$ \\
\hline Food, Beverages \& Tobacco & 0.69 & 0.74 & 0.67 & 0.69 & $10 \mathrm{t} 12$ \\
\hline Textiles & 0.38 & 0.45 & 0.40 & 0.36 & $13 \mathrm{t} 15$ \\
\hline Wood, Paper \& Reproduction & 0.49 & 0.54 & 0.49 & 0.46 & $16 \mathrm{t} 18$ \\
\hline Coke \& Refined Petroleum & 0.88 & 0.88 & 0.89 & 0.87 & 19 \\
\hline Chemicals & 0.90 & 0.81 & 0.88 & 0.91 & $20 \mathrm{t} 21$ \\
\hline Rubber \& Plastics & 0.53 & 0.58 & 0.52 & 0.55 & $22 \mathrm{t} 23$ \\
\hline Basic Metals & 0.45 & 0.47 & 0.94 & 0.45 & $24 \mathrm{t} 25$ \\
\hline Electrical \& Optical & 0.58 & 0.65 & 0.62 & 0.57 & $26 \mathrm{t} 27$ \\
\hline Machinery \& Equipment & 0.49 & 0.53 & 0.51 & 0.49 & 28 \\
\hline Transport Equipment & 0.47 & 0.52 & 0.48 & 0.47 & $29 \mathrm{t} 30$ \\
\hline Others Manufacturing & 0.44 & 0.51 & 0.40 & 0.42 & $31 \mathrm{t} 33$ \\
\hline Wholesale \& Retail, Motor vehicles & 0.47 & 0.46 & 0.57 & 0.47 & 45 \\
\hline Wholesale ex. Motor Vehicles & 0.52 & 0.65 & 0.52 & 0.51 & 46 \\
\hline Retail ex. Motor Vehicles & 0.39 & 0.36 & 0.36 & 0.35 & 47 \\
\hline Transport \& Storage & 1.36 & 0.54 & 1.55 & 1.80 & $49 \mathrm{t} 52$ \\
\hline Postal \& Courier & 0.73 & 0.60 & 1.10 & 0.66 & 53 \\
\hline Publishing \& Audiovisual & 0.54 & 0.47 & 0.64 & 0.51 & $58 \mathrm{t} 60$ \\
\hline Telecommunications & 1.48 & 1.05 & 2.32 & 1.52 & 61 \\
\hline$I T \&$ Others & 0.37 & 0.47 & 0.36 & 0.34 & $62 \mathrm{t} 63$ \\
\hline Agriculture & 0.90 & 0.57 & 0.70 & 0.71 & A \\
\hline Mining \& Quarrying & 0.79 & 0.69 & 0.80 & 0.81 & $\mathrm{~B}$ \\
\hline Utilities & 0.95 & 0.94 & 0.87 & 0.94 & DtE \\
\hline Construction & 0.30 & 0.31 & 0.35 & 0.31 & $\mathrm{~F}$ \\
\hline Accommodation \& Food Services & 0.47 & 0.80 & 0.40 & 0.43 & I \\
\hline Financial \& Insurance & 0.88 & 1.09 & 1.16 & 0.83 & $\mathrm{~K}$ \\
\hline Real Estate & 1.20 & 1.29 & 1.04 & 1.20 & $\mathrm{~L}$ \\
\hline Professional \& Support Activities & 0.56 & 0.68 & 0.67 & 0.49 & $\mathrm{MtN}$ \\
\hline$P A$, Defense \& SS & 0.86 & 1.53 & 1.39 & 0.80 & $\mathrm{O}$ \\
\hline Education & 0.58 & 1.22 & 3.08 & 0.60 & $\mathrm{P}$ \\
\hline Health \& Social & 0.63 & 0.98 & 0.98 & 0.54 & Q \\
\hline Arts \& Recreation & 1.11 & 0.82 & 0.80 & 1.09 & $\mathrm{R}$ \\
\hline Other Service Activities & 1.31 & 1.48 & 0.74 & 0.62 & $\mathrm{~S}$ \\
\hline Average & 0.71 & 0.74 & 0.85 & 0.68 & l \\
\hline
\end{tabular}




\section{Appendix 4. Summary Statistics of Industry Data}

\section{Table A4.1. Mean values of relevant industry characteristics}

\begin{tabular}{|c|c|c|c|c|c|}
\hline & $\begin{array}{c}\text { Share in } \\
\text { value } \\
\text { added }\end{array}$ & $\begin{array}{c}\text { Labor } \\
\text { share }\end{array}$ & $\begin{array}{c}\text { Elasticity } \\
\text { of } \\
\text { substitution }\end{array}$ & $\begin{array}{c}\text { Natural } \\
\text { layoff } \\
\text { rate }\end{array}$ & $\begin{array}{c}\text { Industry } \\
\text { code }\end{array}$ \\
\hline Food, Beverages \& Tobacco & 2.66 & 57.25 & 0.69 & 3.03 & $10 \mathrm{t} 12$ \\
\hline Textiles & 1.25 & 77.51 & 0.38 & 3.73 & $13 \mathrm{t} 15$ \\
\hline Wood, Paper \& Reproduction & 1.86 & 69.14 & 0.49 & 3.81 & $16 \mathrm{t} 18$ \\
\hline Coke \& Refined Petroleum & 0.44 & 41.42 & 0.88 & 1.07 & 19 \\
\hline Chemicals & 2.19 & 47.82 & 0.90 & 2.58 & $20 \mathrm{t} 21$ \\
\hline Rubber \& Plastics & 1.75 & 65.16 & 0.53 & 2.41 & $22 \mathrm{t} 23$ \\
\hline Basic Metals & 2.84 & 68.34 & 0.45 & 3.24 & $24 \mathrm{t} 25$ \\
\hline Electrical \& Optical & 2.33 & 62.48 & 0.58 & 5.62 & $26 \mathrm{t} 27$ \\
\hline Machinery \& Equipment & 1.67 & 71.09 & 0.49 & 2.86 & 28 \\
\hline Transport Equipment & 1.85 & 68.92 & 0.47 & 2.77 & $29 \mathrm{t} 30$ \\
\hline Others Manufacturing & 1.34 & 77.38 & 0.44 & 7.31 & $31 \mathrm{t} 33$ \\
\hline Wholesale \& Retail, Motor vehicles & 1.43 & 69.20 & 0.47 & 2.32 & 45 \\
\hline Wholesale ex. Motor Vehicles & 5.69 & 62.13 & 0.52 & 2.69 & 46 \\
\hline Retail ex. Motor Vehicles & 5.00 & 76.44 & 0.39 & 2.57 & 47 \\
\hline Transport \& Storage & 4.75 & 67.43 & 1.36 & 2.94 & $49 \mathrm{t} 52$ \\
\hline Postal \& Courier & 0.89 & 82.18 & 0.73 & 1.44 & 53 \\
\hline Publishing \& Audiovisual & 1.36 & 65.86 & 0.54 & 3.21 & $58 \mathrm{t} 60$ \\
\hline Telecommunications & 1.73 & 39.35 & 1.48 & 1.98 & 61 \\
\hline$I T \&$ Others & 1.30 & 78.76 & 0.37 & 3.10 & $62 \mathrm{t} 63$ \\
\hline Agriculture & 3.35 & 79.65 & 0.90 & 3.61 & A \\
\hline Mining \& Quarrying & 1.53 & 41.27 & 0.79 & l & $\mathrm{B}$ \\
\hline Utilities & 2.84 & 34.35 & 0.95 & 1.59 & DtE \\
\hline Construction & 6.71 & 78.85 & 0.30 & 6.37 & $\mathrm{~F}$ \\
\hline Accommodation \& Food Services & 2.69 & 76.86 & 0.47 & 3.08 & I \\
\hline Financial \& Insurance & 5.95 & 57.42 & 0.88 & 2.34 & $\mathrm{~K}$ \\
\hline Real Estate & 8.95 & 6.83 & 1.20 & 1.90 & $\mathrm{~L}$ \\
\hline Professional \& Support Activities & 7.20 & 72.87 & 0.56 & 3.68 & $\mathrm{MtN}$ \\
\hline$P A$, Defense \& SS & 7.21 & 76.15 & 0.86 & / & $\mathrm{O}$ \\
\hline Education & 4.90 & 90.20 & 0.58 & 1.35 & $\mathrm{P}$ \\
\hline Health \& Social & 6.01 & 84.21 & 0.63 & 1.78 & Q \\
\hline Arts \& Recreation & 1.12 & 72.34 & 1.11 & 3.40 & $\mathrm{R}$ \\
\hline Other Service Activities & 1.55 & 84.49 & 1.31 & 2.73 & $\mathrm{~S}$ \\
\hline Average & 3.20 & 65.73 & 0.71 & 3.02 & 1 \\
\hline
\end{tabular}




\section{Appendix 5. Stylized Facts.}

In this Appendix we discuss in more detail some stylized facts summarized in Section III. Figure A5.1 plots the coefficients of year fixed effects from a regression of country-industry labor shares on country-industry fixed effects, year fixed effects and a constant. We observe that the labor share has been on a declining trend since the mid-1970s, with the magnitude of such decline somewhat accelerating in the 1990s. Two peculiar periods are the global recessions of the early 1990s and 2009, during which the labor share increased due to a very small decline in labor compensation relative to value added. This is in line with the finding of Kehrig and Vincent (2017) that the labor share tends to modestly increase in recessions, as well as with the presence of sluggish wages as in the model of Rios-Rull and SantaeulaliaLlopis (2010). By including country-time fixed effects, we ensure that this feature is controlled for in our econometric analysis.

We now explore cross-country and cross-industry heterogeneity in the decline of the labor share. In Figure A5.2, we plot estimated linear trends in country labor shares for the 22 countries in our sample, the trend is negative and significant in 15 countries. ${ }^{17} \mathrm{Next}$, we perform a similar exercise for industry labor shares (Figure A5.3). ${ }^{18}$ Of the 32 industries considered, 23 display a negative and statistically significant coefficient, whereas only 4 have a significant positive coefficient. We find some differences in the magnitude of the estimated time trends, but no sector emerges as an outlier. Overall, this exercise confirms that the trend decline in the labor share was rather broad based, taking place both within countries and within industries, while at the same time displaying significant heterogeneity to be explained. ${ }^{19}$

Changes in industrial composition could be important drivers of aggregate country labor share trends. Since our analysis focuses mostly on explaining within-industry changes in the labor share, it is important to quantify how much of the overall time-series variation at the

\footnotetext{
${ }^{17}$ In Figure A5.5 we show linear trends within-industry labor shares by country. For only two countries (Spain and the United Kingdom) does the sign of the estimated linear trend flip (and is significant) when moving from aggregate country to withinindustry labor shares. Importantly, in 13 out of 22 countries we estimate a negative and significant trend, regardless of whether we consider within-industry or aggregate country shares. In Figure A5.6 we plot the median, $25^{\text {th }}$ and $75^{\text {th }}$ percentile of industry labor shares for each country in our sample.

${ }^{18}$ Figure A5.7 reports estimated linear trends in (global) labor shares for each of the 31 industries. Figure A5.8 shows the median, $25^{\text {th }}$ and $75^{\text {th }}$ percentiles of country-specific labor shares for each industry.

${ }^{19}$ Interestingly, we note that linear trends are more precisely estimated (lower standard errors) across different countries for specific sectors and industries, rather than across industries for specific countries. This provides further rationale for an econometric specification that, like ours, also considers industry-specific deterministic components.
} 
country level is explained by within as opposed to between (shifts in industrial composition) changes. To do so, we decompose overall changes according to the following formula (see e.g. Karabarbounis and Neiman 2014):

$$
\Delta L S^{j}=\sum_{i} \bar{\omega}_{i}^{j} \Delta L S_{i}^{j}+\sum_{i} \overline{L S}_{i}^{j} \Delta \omega_{i}^{j}
$$

where $\Delta \mathrm{x}$ denotes the estimated linear trend and $\bar{x}$ the mean of variable $x$. LS refers to the labor share, $\omega$ is the share of added value, while superscript $j$ and subscript $i$ denote respectively country and industry. The first and second terms of the right-hand side of Equation (A5.1) represent the within- and between-industry components of changes in the aggregate country labor share, respectively. Figure A5.4 plots the estimated aggregate country trends in the labor share (y-axis) against the within-industry component (x-axis). The linear regression explains about 70 percent of the country variation. This indicates that within-industry changes are more important than changes in industrial composition in explaining movements at the country level, which supports our country-industry-level analysis. 
Figure A5.1. The global decline in the labor share of income, 1970-2015

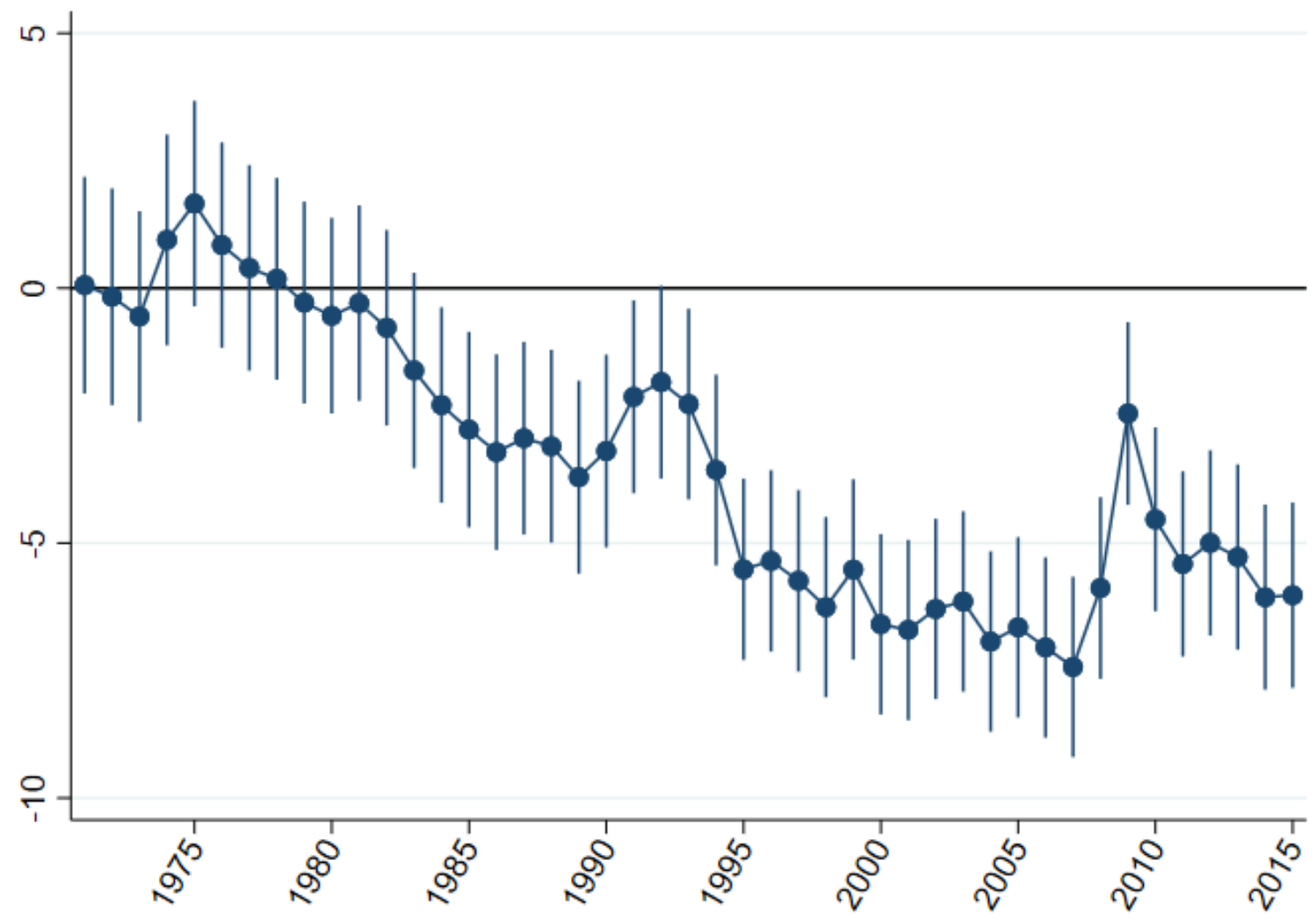

Notes: The Figure shows the coefficients of the year fixed effect from the following regression: $L S_{j i t}=\alpha+\rho_{t}+\gamma_{j i}+\varepsilon_{j i t}$, where the subscripts j, i and t denote, respectively, country, industry and year. LS is the labor share, $\alpha$ is a constant term, $\rho$ are year fixed effects, $\gamma$ are country-industry fixed effects and $\varepsilon$ is the error term. The (blue) red line show estimates from a regression in which industries are (un-)weighted by their relative share. Vertical lines show 1.645 standard errors. Estimates can be interpreted as the average labor share change in percentage points relative to 1970, the base year. 
Figure A5.2. Time trends in country labor shares
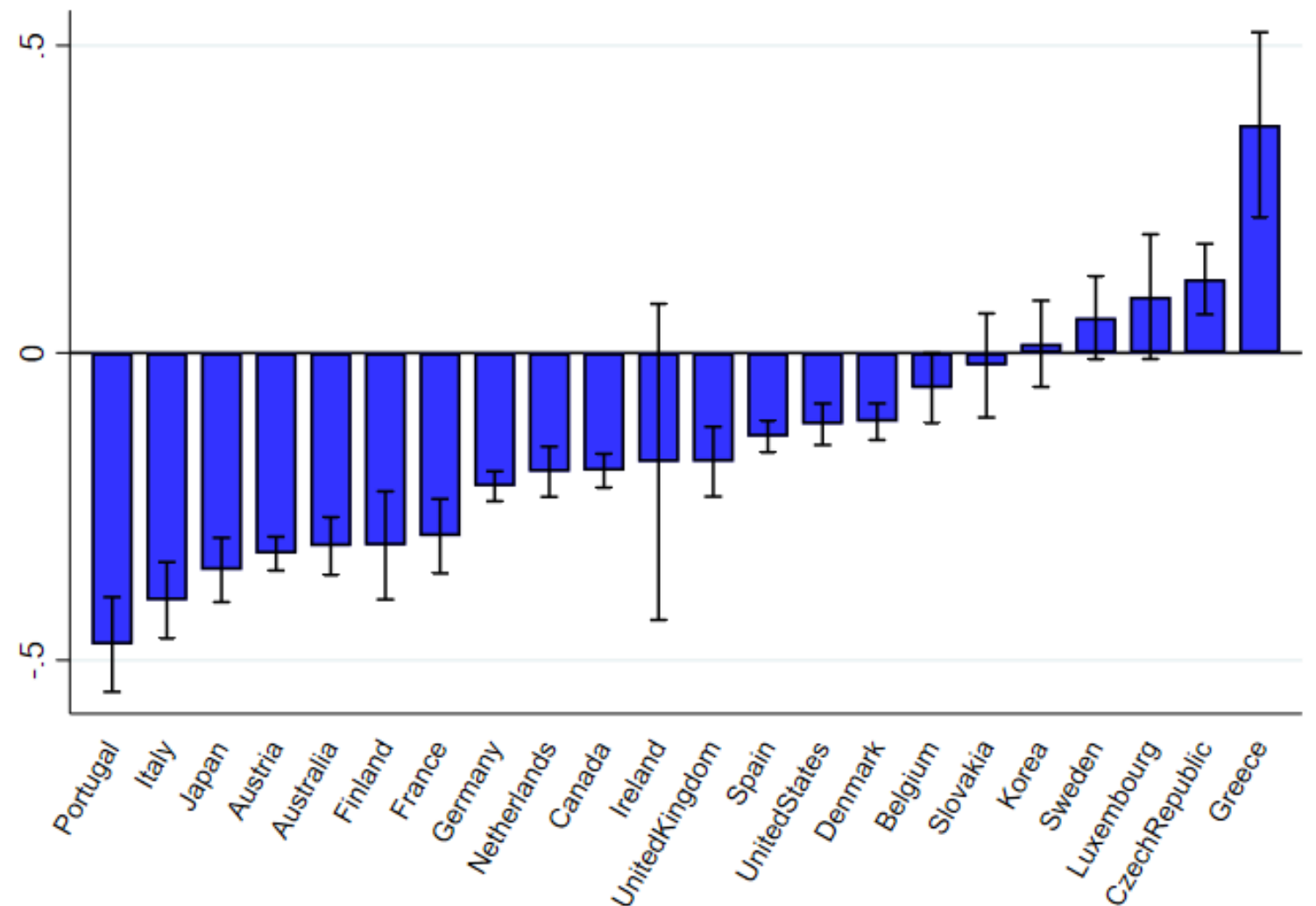

Notes: The Figure shows estimated linear trends in industry labor shares (y-axis) for each country. Trends are estimated from the following regressions: $L S_{t}^{j}=\alpha^{j}+\tau_{t}^{j}+\varepsilon_{t}^{j}$, where the subscript $t$ and the superscript $j$ denote respectively year and country. LS is the labor share, $\alpha$ is a constant term, $\tau$ is the linear trend, and $\varepsilon$ is the error term. Capped spikes denote $90 \%$ confidence intervals. Estimates should be interpreted as the average yearly change in country labor shares over the period considered. The period considered is country-specific and depends on the availability of labor income data in the EU KLEMS database, but is 1970-2015 in most cases. 
Figure A5.3. Linear time trends in industry labor shares

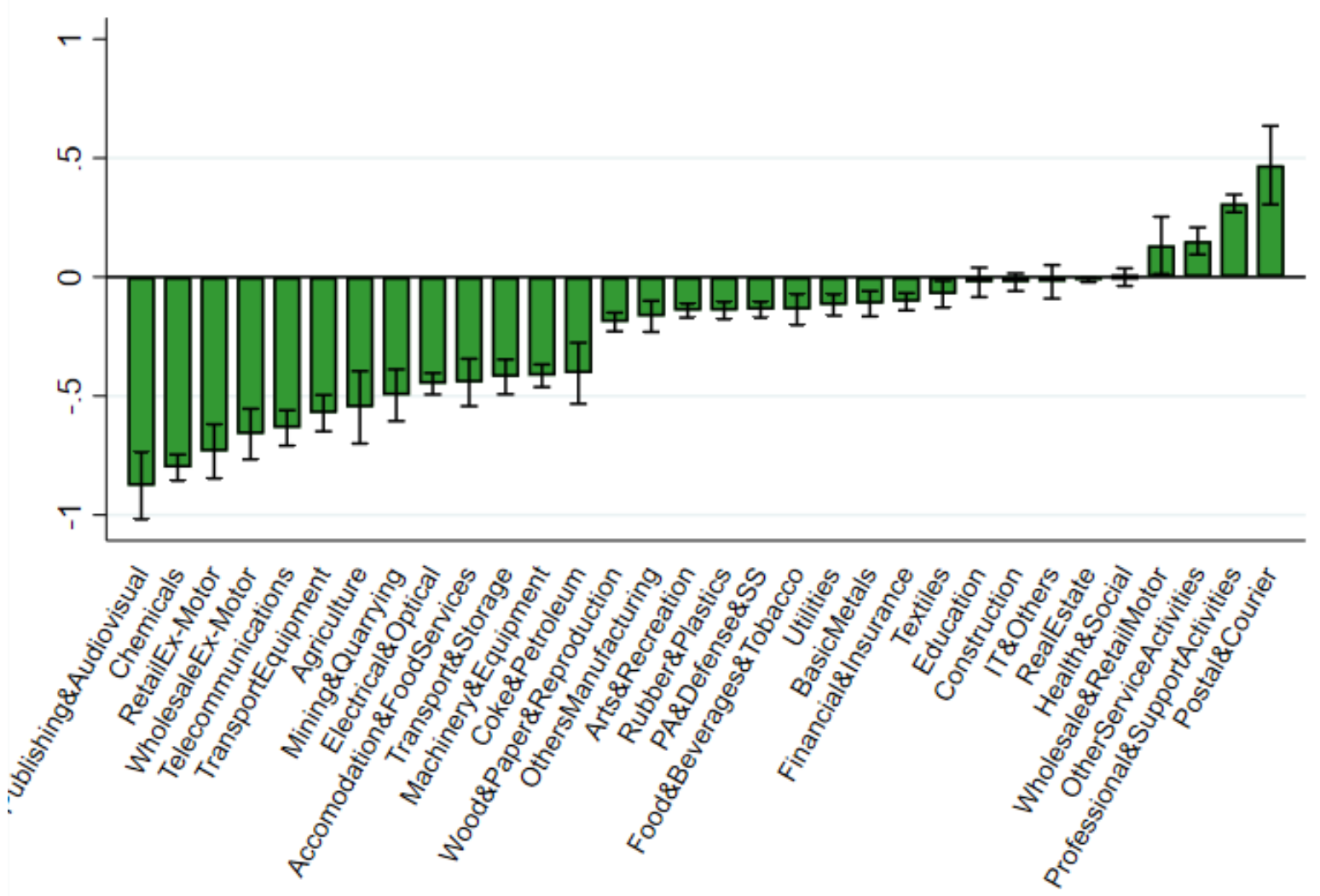

Notes: The Figure shows estimated linear trends in aggregate labor shares (y-axis) for each industry. Trends are estimated from the following regressions: $L S_{t}^{i}=\alpha^{i}+\tau_{t}^{i}+\varepsilon_{t}^{i}$, where the subscript $\mathrm{t}$ and the superscript $i$ denote, respectively, year and industry. LS is the labor share, $\alpha$ is a constant term, $\tau$ is the linear trend, and $\varepsilon$ is the error term. Capped spikes denote $90 \%$ confidence intervals. Estimates should be interpreted as the average yearly change in industry labor shares over the period considered. The period considered is country- and industry- specific and depends on the availability of labor income data in the EU KLEMS database, but is 1970-2015 in most cases. 


\section{Figure A5.4 Within vs. between industry decomposition of changes in labor shares}

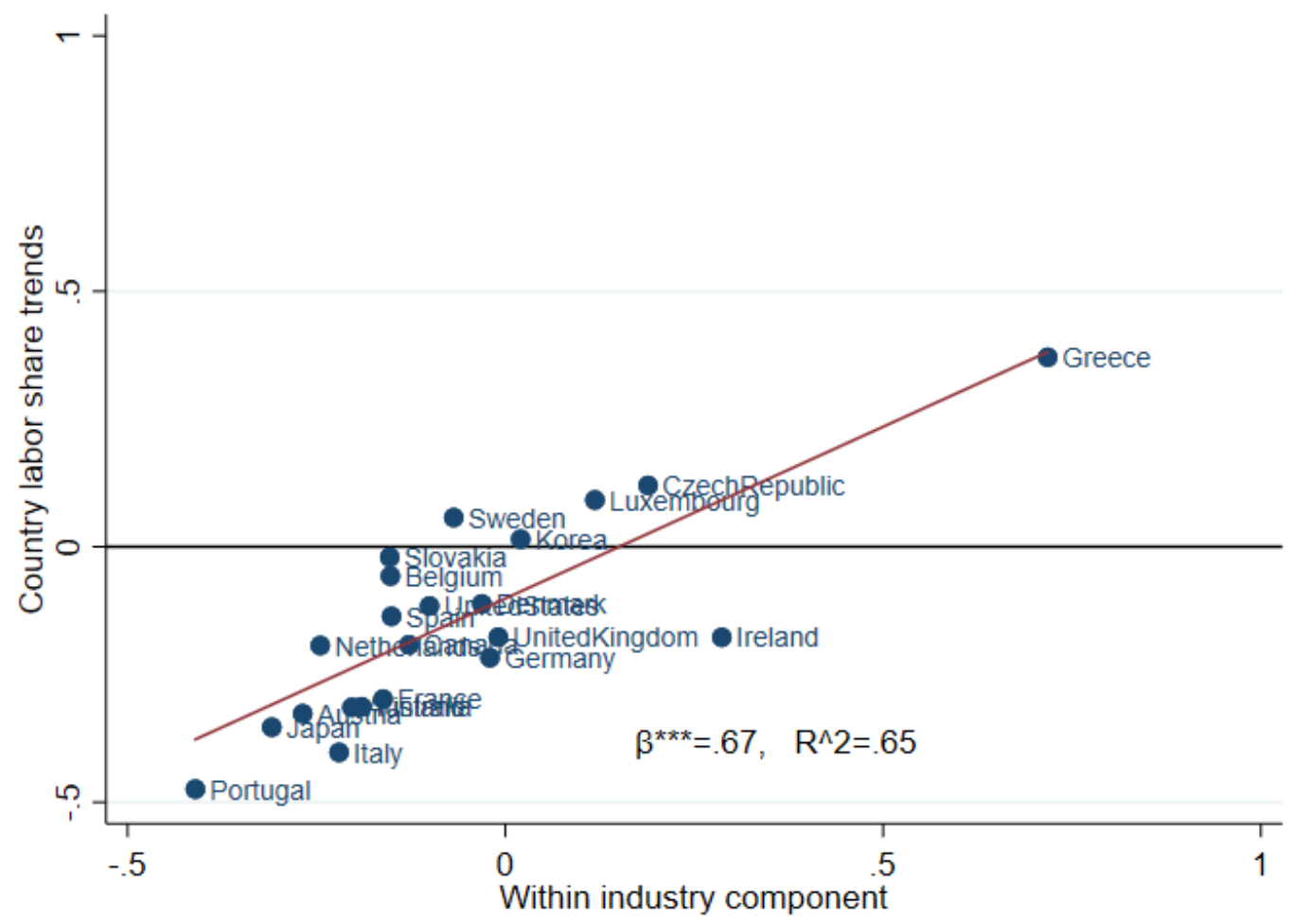

Notes: The figure plots country aggregate labor share trends (y-axis) over the within industry component in labor share trends (x-axis). Country trends are estimated from the following regression: $L S_{t}^{j}=\alpha^{j}+\rho_{t}^{j}+\varepsilon_{t}^{j}$, where the subscript $\mathrm{t}$ and the superscript $\mathrm{j}$ denote, respectively, year and country. LS is the labor share, $\alpha$ is a constant term, $\rho$ are year fixed effects, and $\varepsilon$ is the error term. Within industry components are estimated according to the following expression: $y^{j}=$ $\sum_{i} \bar{\omega}_{i}^{j} \Delta L S_{i}^{j}$, where the superscript $\mathrm{j}$ and subscript i denote respectively country $\mathrm{j}$ and industry $\mathrm{i}, \Delta \mathrm{LS}$ denotes the estimated linear trend in the labor share, $\bar{\omega}$ refer to the mean of the share of added value. 
Figure A5.5 Linear trends in country-industry labor shares, by country

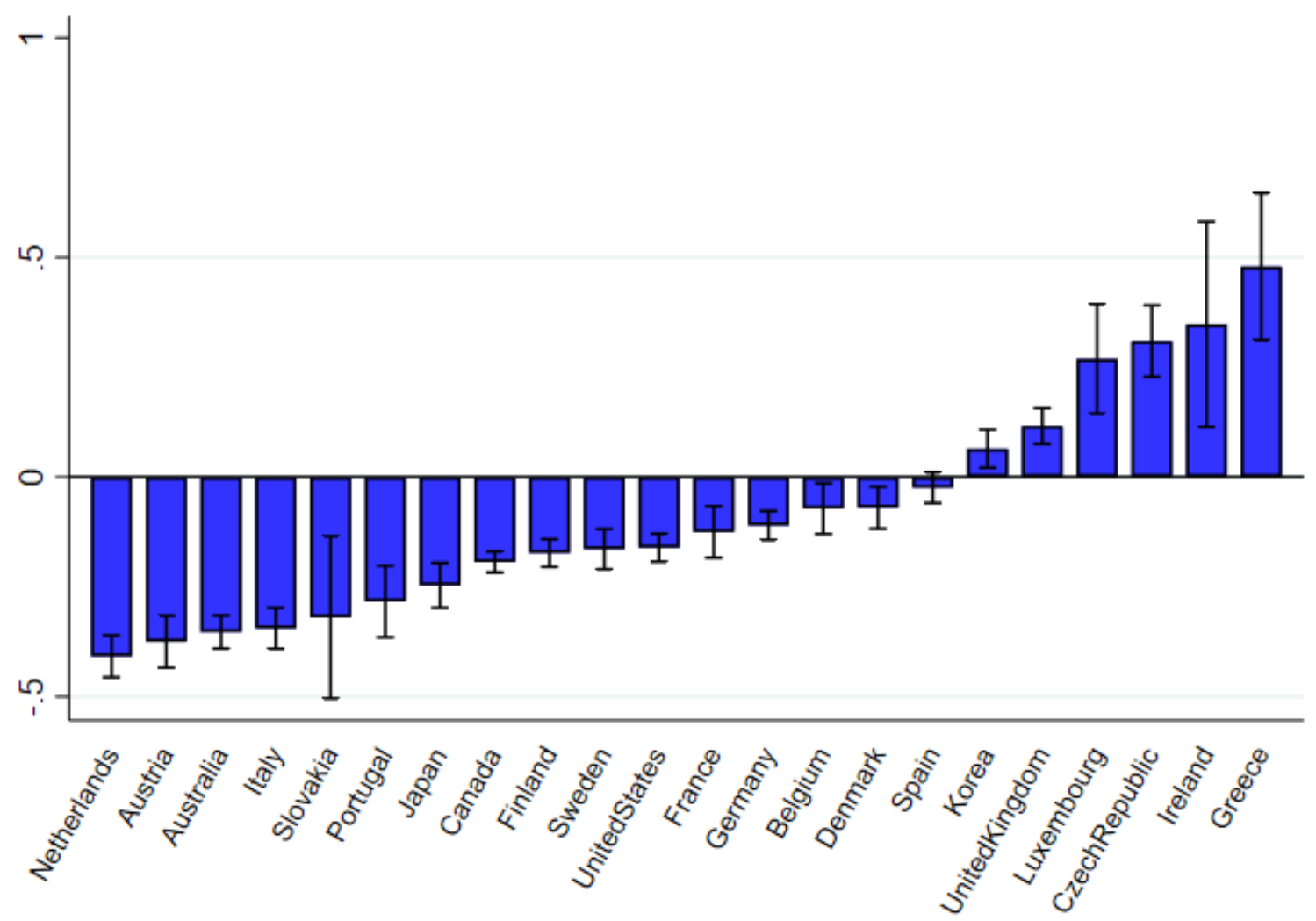

Notes: The Figure shows estimated linear trends in industry labor shares (y-axis) for each country. Trends are estimated from the following regressions: $L S_{i t}^{j}=\alpha^{j}+\gamma_{i}^{j}+\tau_{t}^{j}+\varepsilon_{i t}^{j}$, where the subscripts $i$ and $t$ denote, respectively, industry and year, while the superscript $j$ denotes country. $L S$ is the labor share, $\alpha$ is a constant term, $\gamma$ are industry fixed effects, $\tau$ is the linear trend, and $\varepsilon$ is the error term. Capped spikes denote $90 \%$ confidence intervals. Estimates should be interpreted as the average yearly change in country-industry labor shares over the period considered. The period considered is countryspecific and depends on the availability of labor income data in the EU KLEMS database, but is 1970-2015 in most cases. 


\section{Figure A5.6. Country-industry labor shares, by country}
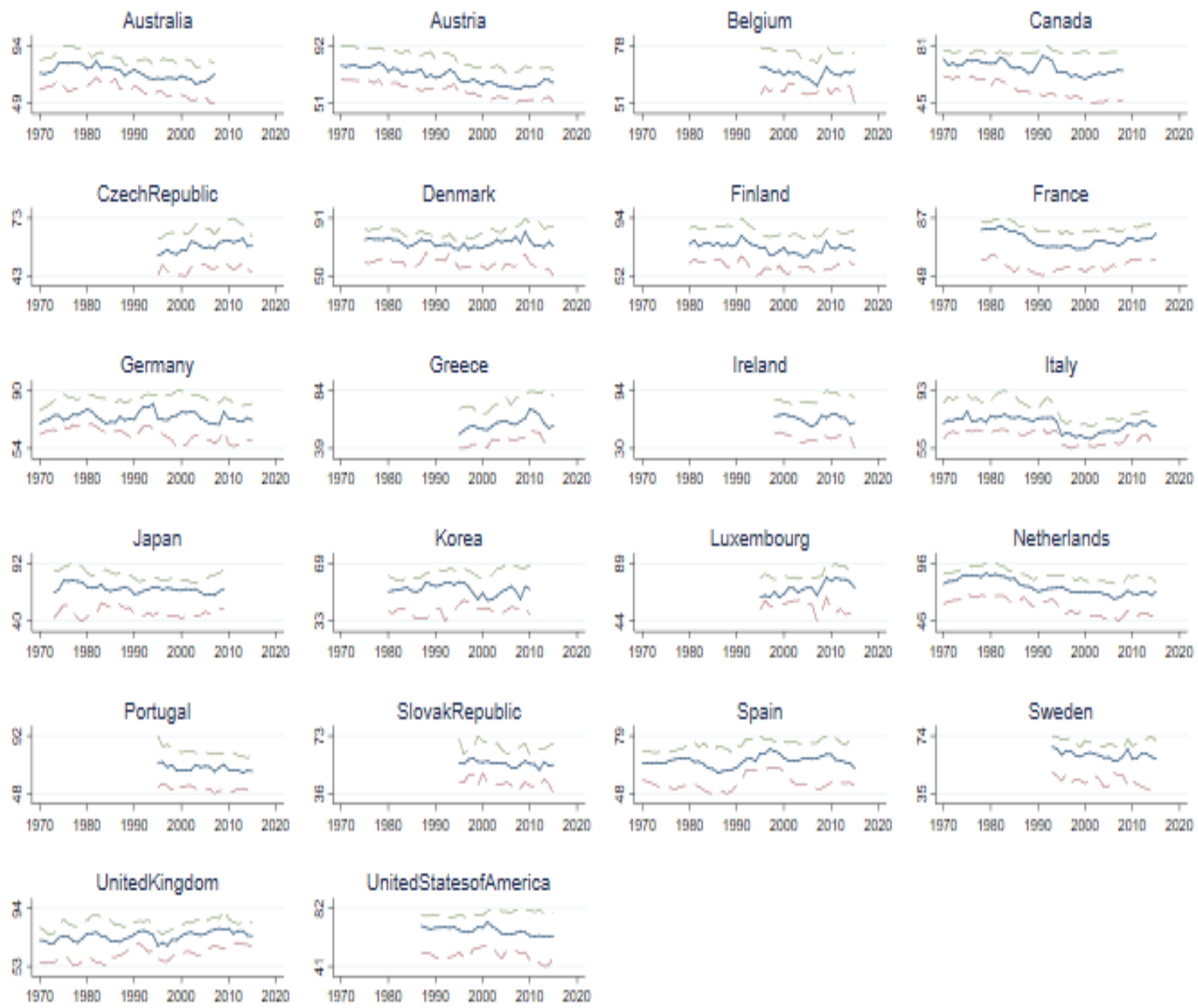

$$
\text { Median }-----25^{\text {th }} \text { pct. } \quad-----75^{\text {th }} \text { pct. }
$$

Notes: The Figure shows the median (solid blue line), $25^{\text {th }}$ percentile (dashed red line) and $75^{\text {th }}$ percentile (dashed green line) of industry labor shares (x-axis) over time (y-axis), for each country in the sample, from 1970 to 2010. 
Figure A5.7. Linear time trends in country-industry labor shares, by industry, 19702015

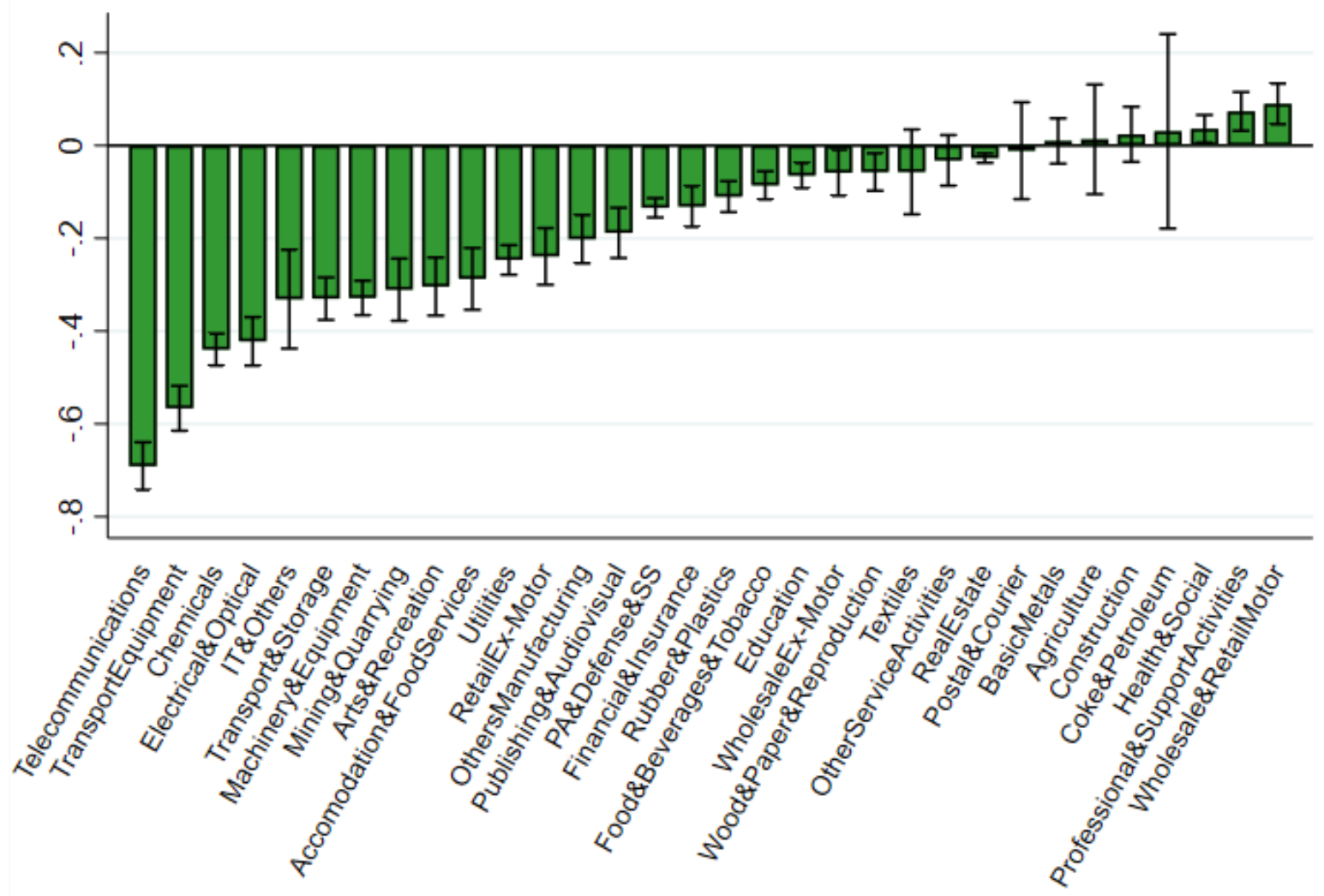

Notes: The Figure shows estimated linear trends in country-specific labor shares (y-axis) for each sector. Trends are estimated from the following regressions: $L S_{j t}^{i}=\alpha^{i}+\gamma_{i}^{i}+\tau_{t}^{i}+\varepsilon_{j t}^{i}$, where the subscripts $j$ and $t$ denote, respectively, country and year, the superscript $i$ denote industry. $L S$ is the labor share, $\alpha$ is a constant term, $\gamma$ are country fixed effects, $\tau$ is the linear trend, and $\varepsilon$ is the error term. Capped spikes denote $90 \%$ confidence intervals. Estimates should be interpreted as the average yearly change in country labor shares over the period considered. The period considered is country- and industry-specific and depends on the availability of labor income data in the EU KLEMS database, but is 1970-2015 in most cases. 


\section{Figure A5.8. Industry-country labor shares, by industry}
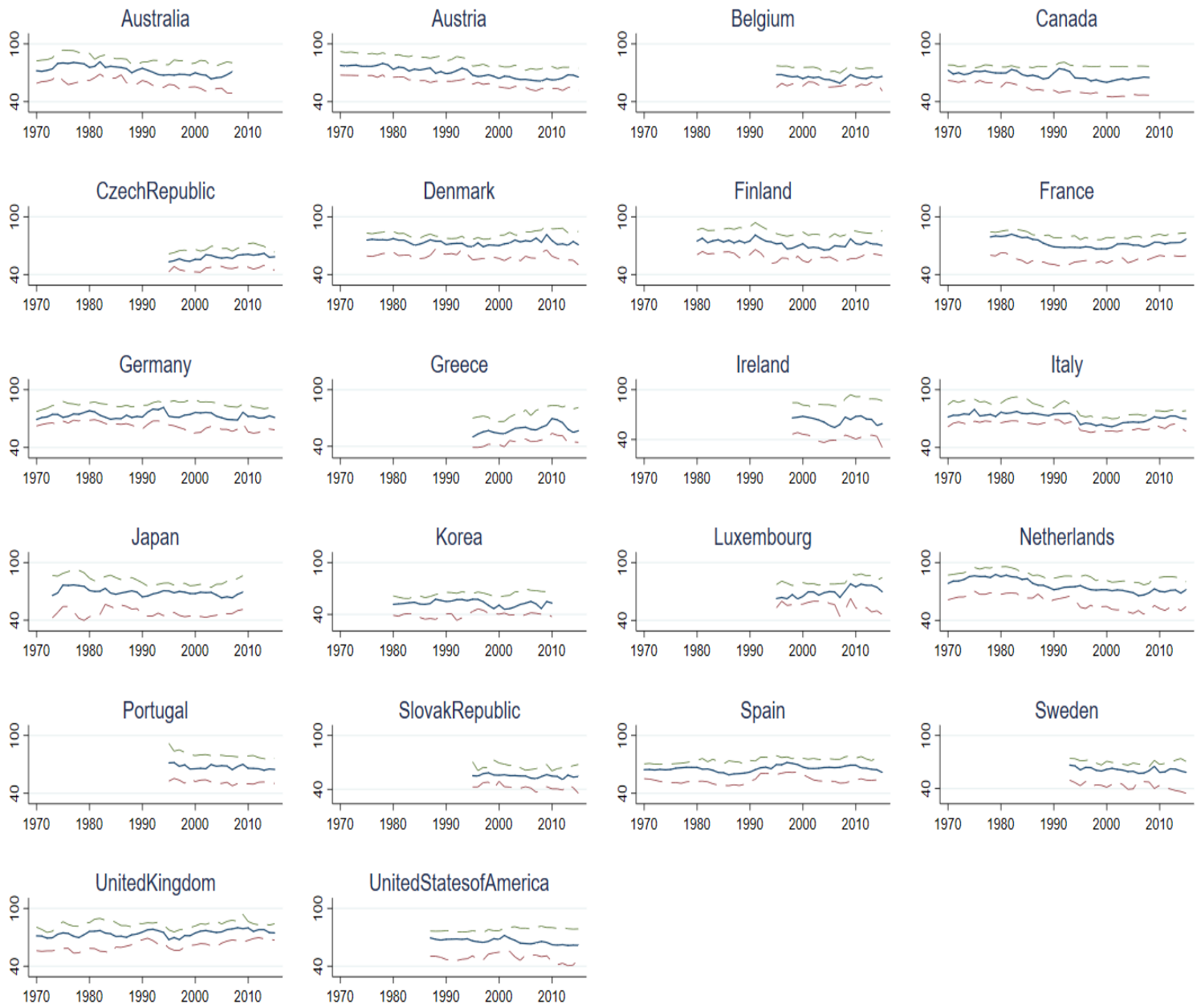

$$
\text { Median } \quad-----25^{\text {th }} \text { pct. } \quad-----75^{\text {th }} \text { pct. }
$$

Notes: The Figure shows the median (solid blue line), $25^{\text {th }}$ percentile (dashed red line) and $75^{\text {th }}$ percentile (dashed green line) of industry labor shares (x-axis) over time (y-axis), for each industry in the sample, from 1970 to 2010. 


\section{Appendix 6. Back-of-the-envelope Calculation Using Country-industry-level Estimates.}

Let us start by writing the labor share in country $j$ at time $t$ as the weighted sum of industry labor shares, with the weight on each industry $i$ given by its value-added share. That is: $L S_{t}^{j} \equiv$ $\frac{w_{t}^{j} L_{t}^{j}}{p_{t}^{j} Y_{t}^{j}}==\sum_{i} L S_{i, t}^{j} \theta_{i, t}^{j}$

where $\theta_{i, t}^{j}$ denotes the added value share of industry $i$. Assuming for simplicity that EPL does not affect the value-added shares of different industries in the economy, the marginal impact of an EPL reform can be written as:

$$
\frac{\partial L S_{t}}{\partial E P L_{t}}=\sum_{i}\left(\frac{\partial L S_{i, t}^{j}}{\partial E P L_{t}} \theta_{i, t}^{j}\right)
$$

Dividing all industries in two groups, denoted by superscripts 1 and 2, and further considering the impact of EPL reform to be the same within each of these groups, one obtains:

$$
\frac{\partial L S_{t}}{\partial E P L_{t}}=\frac{\partial\left(L S_{i, t}^{1}-L S_{i, t}^{2}\right)}{\partial E P L_{t}} \theta_{i, t}^{1}+\frac{\partial L S_{i, t}^{2}}{\partial E P L_{t}}
$$

Using the fact that $\theta_{i, t}^{2}=1-\theta_{i, t}^{1}$ by construction.

If we can further assume that EPL reform has a negligible effect on the labor share in group 2 industries, then the impact of EPL reform on the aggregate labor share becomes:

$$
\frac{\partial L S_{t}}{\partial E P L_{t}} \approx \frac{\partial\left(L S_{i, t}^{1}-L S_{i, t}^{2}\right)}{\partial E P L_{t}} \theta_{i, t}^{1}
$$

We apply this simple formula in the following way. We split industries in two groups, with the first group having a natural layoff rate above the median and an EOS below 1, and the other one consisting of all remaining industries. We then estimate Equation (9) using, as the industry identification variable $\vartheta_{i}$, a dummy taking value $1 / 0$ for industries belonging to the first/second group. Results are reported in Table A6.1. We then further assume that EPL reforms do not have effects in the second group - in line with the statistically insignificant coefficient at the five-year horizon reported in Table 8. Applying the five-year-ahead coefficient estimate to the number of net liberalizing reforms in each country over the period considered, we find that 
changes in EPL may explain about 15 percent of the overall labor share decline. This is roughly similar to the figure obtained using our country-level estimates. ${ }^{20}$

Table A6.1. Country-industry analysis: extension on back-of-the-envelope calculation of aggregate effects

\begin{tabular}{|c|c|c|c|c|c|c|}
\hline & Impact & $1 \mathbf{y}$ & $2 y$ & $3 \mathbf{y}$ & $4 \mathbf{y}$ & $5 y$ \\
\hline \multicolumn{7}{|c|}{ Identification through qualitative 0/1 dummy variable } \\
\hline Labor share & -0.22 & -1.39 & -1.54 & -1.58 & -1.33 & -1.48 \\
\hline Value added & 0.10 & 0.64 & 0.79 & 1.55 & 1.38 & 1.26 \\
\hline
\end{tabular}

\footnotetext{
${ }^{20}$ As noted above, this simple back-of-the-envelope calculation assumes that EPL reforms have no reallocation effects across the two groups of industries. This assumption appears to hold in our data. When re-running Equation (9) with $(\log )$ value added as a dependent variable, we do not find any significant effects of EPL reform. Since this specification controls for aggregate effects by including country-time dummies, the estimated coefficient can be interpreted as the effect of deregulation on the change in value-added shares.
} 